\title{
Prenatal epigenetics diets play protective roles against environmental pollution
}

\author{
Shizhao $\mathrm{Li}^{1 \dagger}$, Min Chen ${ }^{2 \dagger}$, Yuanyuan $\mathrm{Li}^{2,3,4^{*}}$ and Trygve O. Tollefsbol ${ }^{1,3,4,5,6^{*}}$ (D)
}

\begin{abstract}
It is thought that germ cells and preimplantation embryos during development are most susceptible to endogenous and exogenous environmental factors because the epigenome in those cells is undergoing dramatic elimination and reconstruction. Exposure to environmental factors such as nutrition, climate, stress, pathogens, toxins, and even social behavior during gametogenesis and early embryogenesis has been shown to influence disease susceptibility in the offspring. Early-life epigenetic modifications, which determine the expression of genetic information stored in the genome, are viewed as one of the general mechanisms linking prenatal exposure and phenotypic changes later in life. From atmospheric pollution, endocrine-disrupting chemicals to heavy metals, research increasingly suggests that environmental pollutions have already produced significant consequences on human health. Moreover, mounting evidence now links such pollution to relevant modification in the epigenome. The epigenetics diet, referring to a class of bioactive dietary compounds such as isothiocyanates in broccoli, genistein in soybean, resveratrol in grape, epigallocatechin-3-gallate in green tea, and ascorbic acid in fruits, has been shown to modify the epigenome leading to beneficial health outcomes. This review will primarily focus on the causes and consequences of prenatal environment pollution exposure on the epigenome, and the potential protective role of the epigenetics diet, which could play a central role in neutralizing epigenomic aberrations against environmental pollutions.
\end{abstract}

Keywords: Epigenetics diet, Environmental pollution, DNA methylation, Histone modification, miRNA

\section{Background}

A report by the World Health Organization (WHO) estimated that 1.8 billion children (around 93\% of the world's children) breathe polluted air every day, leading to 600,000 children who died from acute lower respiratory infections in 2016. Another recent set of data from WHO shows that in 2012, environmental risk factors, such as air, water and soil pollution, chemical exposures, climate change, and ultraviolet radiation caused 12.6 million deaths, which involve more than 100 diseases and injuries. Accumulating evidence strongly suggests that environmental pollution is seriously affecting human health.

Epidemiological studies suggest that early life, especially prenatal, exposure to environmental factors can induce

\footnotetext{
* Correspondence: lyy@uab.edu; trygve@uab.edu

'Shizhao Li and Min Chen contributed equally to this work.

${ }^{2}$ Department of Pharmacology and Toxicology, University of Alabama at Birmingham, Birmingham, AL, USA

'Department of Biology, University of Alabama at Birmingham, Birmingham, AL, USA

Full list of author information is available at the end of the article
}

persistent metabolic and physiological changes in the fetus through the altered epigenetic profiles leading to different susceptibility to various chronic diseases such as obesity, cardiovascular, diabetes, and even cancer in later life. Epigenetics refer to mitotically or meiotically heritable changes in gene expression without a change in the DNA sequence $[1,2]$. It was first defined by Conrad Waddington in the 1940 s as "...the interactions of genes with their environment which bring the phenotype into being" [3], which provides a potential mechanism through which the environmental factors interact with intrinsic factors and have an impact on gene regulation. Certain chemical modifications to DNA, histone protein and RNA, and non-coding RNAs form a complex regulatory network that modulates the chromatin conformation and gene expression. DNA methylation generally refers to a process by which methyl groups are added to the 5-carbon of the cytosine ring resulting in 5-methylcytosine $(5 \mathrm{mC})$. DNA methylation is almost exclusively found in CpG sites, which are regions of DNA where a cytosine nucleotide occurs next to a guanine nucleotide in the liner sequence of bases along

(c) The Author(s). 2019 Open Access This article is distributed under the terms of the Creative Commons Attribution 4.0 International License (http://creativecommons.org/licenses/by/4.0/), which permits unrestricted use, distribution, and 
its length, in mammals [4]. Histone modifications are a diverse array of post-translational modifications that often occur on tail domains of histone proteins, including acetylation, phosphorylation, methylation, ubiquitination, sumoylation, and adenosine diphosphate (ADP)-ribosylation [5]. The epigenome refers to the complete description of all these potentially heritable changes across the genome [6], among which DNA methylation and covalent modifications of histones are the most important epigenetic regulations that have been well studied.

Mammalian embryos experience two major cycles of epigenetic reprograming including the periods of germ cell development and preimplantation, during which the epigenome is vulnerable to endogenous and exogenous environmental factors. The perturbation of prenatal epigenome reprograming has been shown to influence disease susceptibility in the offspring. The Fetal Basis of Adult Disease (FEBAD) hypothesis postulates that prenatal insults such as nutrition or environmental stimulation can disturb developmental programming leading to a higher risk of disease in later life [7]. The Developmental Origins of Health and Disease (DOHaD), another similar concept that is used to describe developmental plasticity, points to the critical role of environmental cues during the transfer from genotype to phenotype $[8,9]$. Recently, the focus of $\mathrm{DOHaD}$ has extended from poor in utero nutrition to non-nutritional factors that may influence organism's physiology, thus changing disease susceptibility in adulthood. Among these non-nutritional risk factors, early-life exposure to environmental contaminants attracts considerable attention.

Accumulating studies propose that epigenetics may be one of the most important molecular mechanisms linking environmental stimulation, fetal programming, and adulthood phenotype. Due to their reversible nature, epigenetic modifications are becoming an attractive therapeutic target [2]. An increasing body of evidence shows that maternal diets are associated with persistent metabolic changes in the offspring and can substantially improve the health of children and adults, which is referred to as nutritional programming. In this context, nutritional epigenetics emerge and provide a novel way to prevent developmental perturbation by environmental factors. The epigenetics diet, a term coined by our lab in 2011, refers to a class of bioactive dietary compounds that can regulate the epigenome [10]. Studies indicate that the epigenetics diet plays a critical role in epigenetic regulation such as DNA methylation, histone modification, and microRNA (miRNA) regulation. Some bioactive compounds may counteract or attenuate the damage to the epigenome caused by pollution. As a most striking example, it has been shown that maternal supplementation with methyl donors can reverse DNA hypomethylation induced by bisphenol $\mathrm{A}$, an endocrine-disrupting chemical of public health concern [11].
The purpose of this review is to provide a summary of recent research findings on the influence and causes of early life, especially prenatal exposure, to environmental contaminants on the epigenome, and the potential mechanisms through which parental epigenetic dietary supplementation prevents environment pollution-induced adverse effects. Our review will provide implications into new preventive and therapeutic strategies for coping with increasingly severe environmental pollution.

\section{Epigenetic stability during gametogenesis and embryonic development}

The mammalian embryo undergoes two large-scale waves of epigenomic reprogramming (Fig. 1): the first wave takes place from sperm-egg fusion to preimplantation; the second wave happens during genesis of germ cells $[12,13]$. Here, we review the DNA methylome, which is one of the most important components in the epigenome, reprogramming in mammals, and its susceptibility to the environment.

\section{Epigenomic reprogramming during early embryogenesis} After fertilization, a dramatic demethylation takes place in the early embryo. The amount of methylation in sperm (86\%, median) and in oocyte $(72 \%$, median) rapidly reduce and reach their minimum level (43\%, median) in the inner cell mass (ICM) of the early blastocyst-stage embryos (3264 cells) $[14,15]$. In this process, early gamete-specific methylation patterns inherited from the parents as well as acquired epigenetic modifications are erased, while methylated regions in imprinted genes are accurately retained, which is crucial to pluripotency establishment. For instance, the imprinted genes $H 19$ [16] and Rasgrf1 [17] in the paternal genome are protected from extensive demethylation after fertilization [18], under the action of DNA methyltransferase 1 (DNMT 1) [19]. Before genome-wide demethylation, remarkable transformation of the paternal genome occurs in the egg cytoplasm, where protamine of sperm chromatin is replaced by acetylated histones, suggesting that demethylation may be linked to chromatin remodeling [18]. A recent study found that after the two-cell stage, demethylation occurring in the paternal genome is much faster and thorough than that in the maternal genome, and this higher maternal genome methylation is maintained until the post-implantation stage, especially in the extra-embryonic villus $[20,21]$. This finding indicates that the DNA methylome is asymmetrically distributed in the maternal and paternal genomes. Conversely, compared to the paternal genome, the maternal genome may contribute more DNA methylation memory to the early embryo; thus, adverse environmental factors such as pollutants, virus and malnutrition are more likely to change methylation patterns in the maternal genome during gametogenesis leading to acute dysplasia and disease susceptibility in later life. It is 


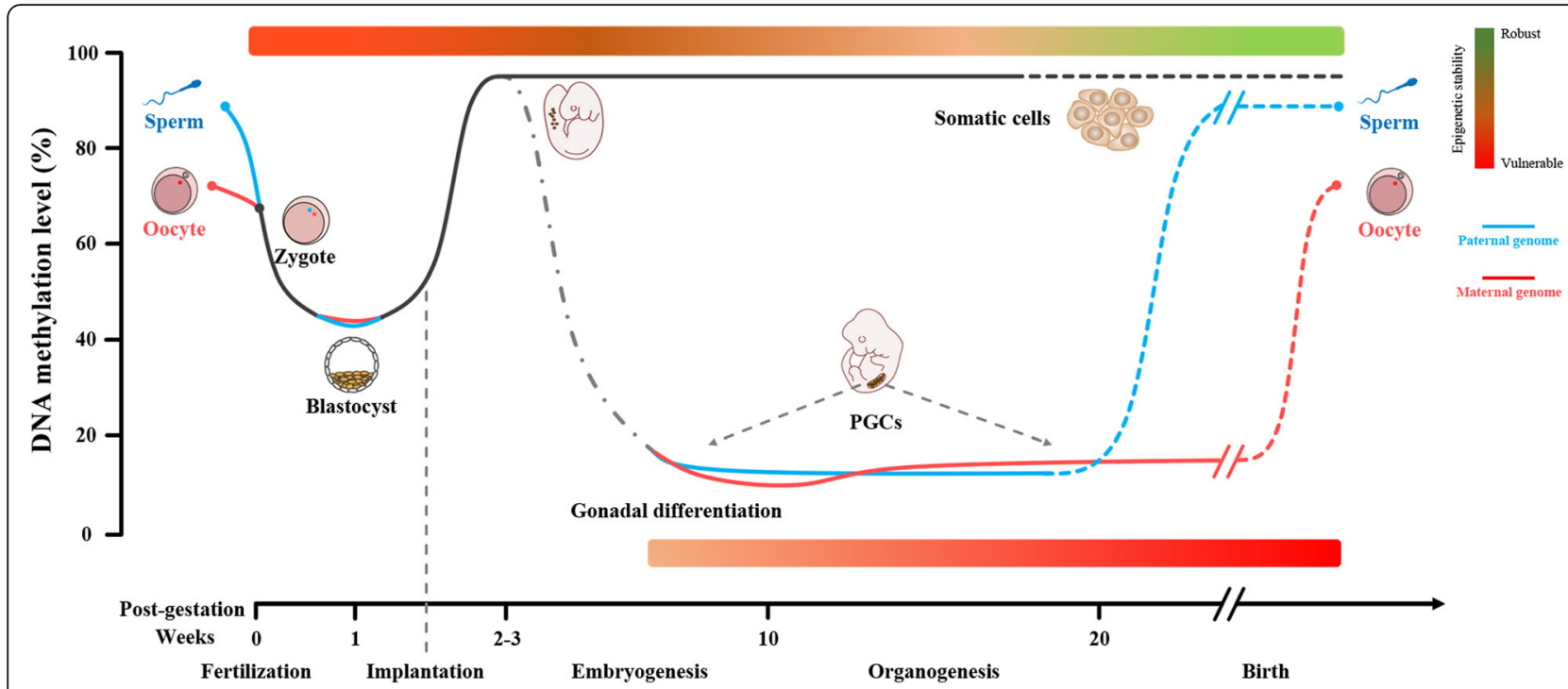

Fig. 1 Schematic of DNA methylation dynamic and epigenetic stability during gametogenesis and embryogenesis in humans. DNA methylome reprogramming in germ cells: primordial germ cells (PGCS) in the human become demethylated early in development; from gonadal differentiation to gametogenesis, DNA methylation of spermatocyte and oocyte cells rises gradually until fertilization, at which point sperm reaches a higher methylation level than the oocyte. DNA methylome reprogramming during embryonic development: after fertilization, within the first week, the methylation level of the zygote decreases to the lowest level at the early blastocyst period, during which DNA methylation of the paternal genome reaches a lower level; subsequently, de novo methylation occurs in somatic cell lineages, until they develop into mature somatic cells with stable methylation levels. Epigenetic stability during development: epigenetic stability is proportional to DNA methylation levels. The blue line represents the paternal genome. The red line indicates maternal genome. The gray dashed line denotes mature somatic cells. From red to green, signifies from vulnerable to robust of the epigenome. PGCS, primordial germ cells. Adapted and used with permission from Guo et al. [14], Hemberger and Pedersen [46] and Zhu et al. [20]

noted that demethylation and de novo methylation keep dynamic equilibrium before global methylation of the early embryo reaching the lowest level at the blastula stage [20]. After implantation, the first wave of de novo methylation occurs [1], and DNA methylation patterns are reestablished by DNMTs in the blastocyst stage. Curiously, however, the timing of remethylating the paternal epigenome is earlier than the maternal one, among which H19 is a typical example [22]. At about 2-3 weeks of age, the cells in the human embryo are gradually developing into mature somatic cells with relatively stable methylation levels [14] (Fig. 1).

\section{Epigenomic reprogramming during gametogenesis}

Human primordial germ cells (PGCs) are produced in the early stage of embryonic development. PGCs are the embryonic progenitors of oocytes and sperm [15], which can transmit genetic information to offspring and maintain the continuance of the species. Under normal circumstances, DNA methylation markers on genomic DNA of most tissues and organs in the post-implantation embryo will remain basically stable, whereas the DNA methylome in PGCs will experience the second massive elimination and reconstruction, which is much more thorough than the first wave in preimplantation embryos [14]. Approximately 10-11 weeks after gestation, the global DNA methylation of PGCs are drastically decreased from over $90 \%$ in the early post-implantation embryo to only $7.8 \%$ and $6.0 \%$ in male and female PGCs, respectively [14]. Although DNA methylation memory in most regions of PGCs is completely erased, some repetitive sequences still retain higher levels of residual methylation, especially the evolutionarily younger sequences and the alpha satellites $[14,23,24]$, suggesting a basis for potential transgenerational epigenetics. After a period of hypomethylation, remethylating of the male germ cells takes place during late embryonic development, whereas de novo methylation in the female germ cells occurs after birth, due to a protracted developmental process. It has been shown that global DNA methylation of human sperm cells is higher than that in oocytes [14]. There are three likely purposes of reprogramming in germ cells: resetting of imprints, which mainly occurs in species with imprinting [18]; removal of acquired epigenetic modification influenced by individual endogenous and exogenous environmental factors $[18,25,26]$; and reducing mutation rate caused by active demethylation [27] and X-chromosome inactivation [28, 29] (Fig. 1).

Epigenomic reprogramming during later-life development Fetal adaptation, an emerging concept in recent years, interprets the role of epigenetic regulation later in development, which is separated from early embryogenesis and implantation. In this context, subtle epigenetic modifications allow the fetal genotype to respond to a broad 
variety of developmental environmental factors. Although early gestation is the most susceptible period for the fetus, it should be noted that environmental stimulation in late embryonic development, infancy, and early childhood can also have long-term health implications in later life $[9,30]$. Studies have shown that a high-fat diet (HFD) supplemented in adulthood induced large-scale methylation alteration in skeletal muscles [31]. Folic acid supplementation during the peri-pubertal period has been shown to induce hypermethylation of the PPAR $\alpha$ gene and a decrease in DNMT activity [32, 33]. In addition, post-weaning mice supplemented with methyl donors-deficient diet showed a permanent loss of IGF2 imprinting, dysregulation of mRNA expression, and hypomethylation of the proto-oncogenes such as $c-M y c$ and $c-$ Ras [34]. All these studies suggest that plasticity of the human epigenome may also persist into adulthood [31] and epigenetic mechanisms are involved in life-long adaptation [35].

\section{The roles of DNA methylation in gene expression and cellular identity}

As one of the most important of the epigenetic modifications, DNA methylation can play a key role in local control of gene expression. CpG islands (CGIs) are short interspersed DNA sequences with a high frequency of $\mathrm{CpG}$ sites that are predominantly non-methylated [36]. A CGI is generally defined as a region with at least $200 \mathrm{bp}$ and a CG percentage greater than $50 \%$. The multiple methylated CpG sites in CGIs of promoters and distal regulatory regions may destabilize nucleosomes and recruit proteins, resulting in chromatin structure remodeling and transcriptional inhibition [37]. Methylated CpG sites can be recognized by different sets of methyl-CpG-binding proteins (MBPs), which then translate the DNA methylation signal into transcriptional repression states through attracting epigenetic modifiers to manage site-specific chromatin organization [38]. On the other hand, the methylation of $\mathrm{CpG}$ sites can block the binding of certain transcription factors, such as E2F1, c-Myc, CTCT, and CREB, obstructing transcription initiation [39]. DNA methylation can also reposition nucleosomes leading to remodeling transcription complexes and interrupting gene transcription. In addition, increasing evidence has indicated that gene expression may be simultaneously regulated by the methylation levels in the promoter region and the gene body [40, 41].

DNA methylation is also crucial and essential for the establishment and maintenance of cellular identity. Global hypomethylation is required for the pluripotency of embryonic stem cells (ESCs) [42]. During cell differentiation, ESCs gradually lose their plasticity and narrow their identity into differentiated cell types. In this process, there is a global gain of DNA methylation in pluripotency, developmental, and gamete-specific genes, along with the loss of DNA methylation in lineage-specific regulatory regions as well as gene enhancer regions, to define cell identities with different methylomic profiles [39]. As different tissues and organs have different methylomes, exposure to environmental factors may lead to altered DNA methylation patterns and adverse health outcomes in a tissue-specific manner [43-45].

\section{Epigenetic stability and environmental factors}

Epigenetic stability is proportional to the amount of DNA methylation and histone modification in the static model [46]. Global hypomethylation of genomic DNA can lead to genomic instability and structural abnormalities in chromosomes, which is also a common phenotype of cancer and aging [47, 48]. Conversely, global hypermethylation, especially in the placenta, has been linked with developmental defects such as gestational diabetes and Down's syndrome $[49,50]$. Together, these show that the balance of DNA methylation is crucial for human genetic stability and individual health. In the dynamic model, epigenetic modification is reversible, thus making the epigenome persistently vulnerable. The proportion of stem cells contributes to epigenetic vulnerability of the organism, indicating that the gradual decline of overall epigenome stability with development may arise from, at least in part, the decrease of stem cell proportion in tissues and organs [46].

The epigenome, especially DNA methylation patterns in mammals including humans, is overall established in gametogenesis and early embryogenesis. The plasticity of the epigenome also contributes to the generation of cells with a broad developmental potential [18]. In this regard, epigenetic reprogramming in germ cells and the preimplantation embryo is particularly important for early embryonic and placental development [51]. This leads to a speculation that perturbations of the epigenome in early developmental stages contribute to abnormal fetal and placental development [52]. The epigenetic dysregulation triggered by environmental cues during these sensitive periods of individual development can persist across the life course leading to altered disease susceptibility and even phenotypic changes later in life $[13,14]$.

Studies have confirmed the developmental plasticity by which a specific genotype can give rise to a range of phenotypes in response to persistent environmental conditions during development [53-55]. $\mathrm{DOHaD}$ phenomenon also describes the relationship between early environmental cues and later-life risk of abnormal metabolism and other diseases, where epigenetic mechanisms could be the bridge connecting these factors [56-58]. The timing of an intervention is the key to epigenetic alteration in response 
to environmental pollutants such as endocrine-disrupting chemicals and heavy metal or bioactive food components. For instance, our recent studies showed that prenatal phytochemicals may affect epigenetic patterns more profoundly than the same exposure in postnatal or adulthood [59]. Likewise, the time windows of the intervention are particularly important for the efficacy of epigenetic perturbation to prevent individual abnormal development [60].

\section{Prenatal environmental pollution and epigenetic dysregulation}

The concept of developmental programming emphasizes that during sensitive windows of vulnerability, environmental intervention may result in functional dysregulation of gene expression and disease pathogenesis in later life [61]. Early-life development, in particular during embryogenesis, has been shown to play an important role in the initiation and development of many chronic metabolic diseases as well as cancers, and epigenetic mechanisms have been suggested to be involved in these processes [35]. The general epigenome, including DNA methylation and histone modifications, is established in the early embryo and the germ cells and has been thought to maintain a very stable modification status throughout the life course. An expanding body of evidence has confirmed that environmental stimuli such as climatic factors and environmental toxicants, occurring especially during prenatal and early postnatal life, may alter epigenetic programming leading to altered disease susceptibility or irreversible phenotypic changes in the offspring [62]. Among these risk factors, prenatal exposure to environmental contaminants attracts more attention and has been repeatedly found to be associated with aberrant epigenetic modification of regulatory sequences in susceptible genes $[63,64]$. Here, we review several prenatal environmental pollutants in different categories and their potential impacts on embryonic and postnatal development through epigenetic regulation.

\section{Ambient air pollution}

Ambient air pollution includes particulate matter (PM) of various sizes and composition, as well as gaseous pollutants [65]. Early-life exposure to air pollution, especially during gestation, is a major health threat to pregnant women [66] and the developing fetus as well as the children. Air pollution has been shown to associate with various allergic complications both in short-term and long-term influence [67-69] as it can cross the placenta $[15,70,71]$. Although the specific molecular mechanisms underlying the effect of air pollution are not fully understood, epigenetic modifications are believed to be one of the key contributors that may link air pollution exposure to a range of adverse health outcomes $[15,72]$.

\section{Particulate matter}

Studies have shown PM with a diameter smaller than $500 \mathrm{~nm}$ can pass the placental barrier and particles even can reach the fetal bloodstream when their diameters are smaller than $240 \mathrm{~nm}$ [71]. Janssen et al. found that exposure to particles with aerodynamics diameter smaller than $2.5 \mu \mathrm{m}$ (PM2.5), with $5 \mu \mathrm{g} / \mathrm{m}^{3}$, resulted in a decrease $(2.2 \%)$ of global DNA methylation in placenta tissue [73]. It should be noted that altered placental global DNA methylation [73, 74] and gene-specific (LINE1 and HSD11B2) methylation [75] were observed only when exposed to PM2.5 during early pregnancy, which includes the period from fertilization up to implantation and is most sensitive to environmental stress. Studies have also reported that prenatal exposure to PM was associated a decrease in placental mitochondrial DNA (mtDNA) contents [76] and DNA hypomethylation of the mitochondrial genome [77]. PM2.5 exposure has been shown to be linked with a decrease $(0.2-2.7 \%, P<$ 0.05 ) of DNA methylation in the promoter region of the leptin gene, which is an important hormone during gestation and plays a key role in energy metabolism [78], as well as hypermethylation of the PARP promoter [79]. In addition, maternal exposure to particles also targets miRNAs. A decrease in expression of miR-21, miR-146a, and miR-222 was found to associate with PM2.5 exposure during the second trimester of pregnancy, whereas an increase in expression of miR-20a and miR-21 was observed during the first trimester [80] (Table 1).

\section{Smoking}

Maternal tobacco smoke is a personalized form of air pollution for the mother herself and fetus [73]. Although smoking is controllable, more than half of female smokers continue to smoke after pregnancy [81]. In utero exposure to smoking is associated with alterations of DNA methylation patterns [82-85], and such changes may persist throughout the entire life course [85-88], leading to impaired fetal development [83, 89], preterm delivery [90, 91] and other chronic diseases including respiratory illness, cardiovascular disorders, and certain childhood cancers in the offspring's later life [92-94]. The methylation targets of maternal smoking during pregnancy could be genome-wide $[85,95-101]$ and specific such as runt-related transcription factor 3 (RUNX3), aryl hydrocarbon receptor repressor $(A H R R)$, and cytochrome $\mathrm{P} 450$ 1A1 (CYP1A1) in placental tissue [44, 102, 103]; AHRR, growth factor independent 1 (GFI1), insulin-like growth factor 2 (IGF2), PR domain containing 8 (PRDM8), discs large homolog-associated protein 2 (DLGAP2), thymic stromal lymphopoietin (TSLP), CYP1A1 in newborn umbilical cord blood samples [44, 85, 104-106]; and Myosin 1 G (MYO1G), cortactin-associated protein-like 2 (CNTNAP2), and FRMD4A, a human epidermal stem cell 
Table 1 Summary of human studies reporting associations between prenatal exposure to air pollution and epigenetic alterations

\begin{tabular}{|c|c|c|c|}
\hline Pollution & $\begin{array}{l}\text { Exposure } \\
\text { stage }\end{array}$ & Epigenetic change & Ref. \\
\hline \multirow[t]{8}{*}{ Particulate matter } & Prenatal & Altered DNA methylation at CpG sites & [65] \\
\hline & First trimester & Positive correlation with placental global DNA methylation & [74] \\
\hline & $\begin{array}{l}\text { Second } \\
\text { trimester }\end{array}$ & Lower placental leptin promoter methylation & [78] \\
\hline & Early pregnancy & Associated with placental DNA methylation of LINE1 and HSD11B2 & [75] \\
\hline & Prenatal & $\begin{array}{l}\text { Decreased expression of miR-21, miR-146a and miR-222; increased } \\
\text { expression of miR-20a and miR-21 }\end{array}$ & [80] \\
\hline & Gestation & Increased mtDNA methylation levels and decreased LINE-1 methylation levels & [77] \\
\hline & Prenatal & Decrease in global DNA methylation for whole pregnancy & [73] \\
\hline & Prenatal & Increased DNA methylation in LINE1, OGG1, APEX and PARP1 & [79] \\
\hline \multirow[t]{22}{*}{ Smoking } & Prenatal & Nearly 3000 CpGs corresponding to genes differentially methylated in offspring & [85] \\
\hline & Maternal & $\begin{array}{l}\text { Altered DNA methylation levels at CpG sites of GFII, AHRR and PRNP gene in male } \\
\text { and female, differentially }\end{array}$ & [110] \\
\hline & In utero & Impact key biological pathways through epigenetic modification & [84] \\
\hline & Maternal & Differential methylation of MYO1G, CNTNAP2 and FRMD4A genes in children blood & [107] \\
\hline & In utero & Global DNA hypomethylation; 31 CpG sites associated to 25 genes & [99] \\
\hline & Prenatal & Altered methylation at $15 \mathrm{CpG}$ sites & [100] \\
\hline & Prenatal & $\begin{array}{l}\text { Differential methylation at five CpGs in MYO1G and CNTNAP2; persist in exposed offspring } \\
\text { for many years }\end{array}$ & [88] \\
\hline & In utero & $\begin{array}{l}\text { Increased CpG methylation in FRMD4A and Cllorf52; reproducible epigenetic changes persist into } \\
\text { childhood }\end{array}$ & [87] \\
\hline & In utero & Altered methylation at $185 \mathrm{CpGs}$ of 110 gene regions in infants & [101] \\
\hline & In utero & Hypomethylation of AHRR in the cord blood mononuclear cells, buccal epithelium and placenta tissue & [44] \\
\hline & In utero & Altered methylation at TSLP promoter & [106] \\
\hline & Maternal & Altered methylation patterns of a few loci within the RUNX3 gene & [102] \\
\hline & In utero & Increased IGF2 DMR & [105] \\
\hline & In utero & Altered LINE-1 and AluYb8 methylation levels & [83] \\
\hline & Maternal & Differential DNA methylation at epigenome-wide for 26 CpGs mapped to 10 genes & [104] \\
\hline & Maternal & Differential epigenome-wide placental DNA methylation & [82] \\
\hline & Gestation & Decreased methylation of Sat2 & [96] \\
\hline & Maternal & Increased DNA methylation in the BNDF-6 exon & [108] \\
\hline & Gestation & Downregulation of miR-16, miR-21 and miR-146a in placenta & [109] \\
\hline & In utero & Global DNA methylation inversely correlates with cotinine levels in cord blood & [95] \\
\hline & In utero & Decreased methylation at CYPIAI promoter in the placenta & [103] \\
\hline & Prenatal & $\begin{array}{l}\text { Lower methylation of AluYb8; differential methylation of LINE1; increased methylation } \\
\text { of AXL and PTPRO }\end{array}$ & [98] \\
\hline \multirow{3}{*}{$\begin{array}{l}\text { Polycyclic aromatic } \\
\text { hydrocarbons }\end{array}$} & Prenatal & Inverse relationship with LINE1 DNA methylation in cord blood & [119] \\
\hline & Prenatal & Decreased global methylation in umbilical cord white blood cells & [118] \\
\hline & Prenatal & Altered methylation in $5^{\prime}-\mathrm{CpG}$ islands of $A C S L 3$ & [120] \\
\hline \multirow[t]{2}{*}{$\mathrm{NO}_{2}$} & Prenatal & Related alteration of $A D O R A 2 B$ methylation & [65] \\
\hline & Prenatal & Differential offspring DNA methylation in antioxidant and mitochondria-related genes & [122] \\
\hline
\end{tabular}

marker, in children's blood [107]; MYO1G, CNTNAP2, and brain-derived neurotrophic factor $(B D N F)$ in adolescent's peripheral blood cells [88, 108]; and repetitive element satellite 2 (Sat2) in adult peripheral blood granulocytes [96], as well as $A H R R$, in neonatal buccal epithelium [44]. Maternal tobacco smoking has been also linked to dysregulated expression of miRNAs. Maccani et al. [109] demonstrated that smoking during pregnancy 
downregulated the placental expression of miR-16, miR-21, and miR-146a that may influence fetal programming. Interestingly, the impact of prenatal cigarette smoke on DNA methylation may be gender-specific. It was shown that the male fetus is more susceptible to maternal smoking than the female [110], and the alteration of DNA methylation in the differentially methylated region (DMR) of the IGF2 gene was more notable among newborn boys than girls [105], whereas Bouwland-Both reported an adverse result [111]. Moreover, a study has shown that maternal smoking showed a much stronger impact on offspring methylation intensity than paternal smoking [15] (Table 1).

\section{Polycyclic aromatic hydrocarbons}

Polycyclic aromatic hydrocarbons (PAHs) are aromatic hydrocarbons with two or more fused benzene rings [112]. They are mainly formed during incomplete combustion of fossil fuel, domestic wood, and other organic materials that are widely distributed in the air [113]. PAHs are persistent organic pollutants (POPs) that have detrimental biological effects such as genotoxicity and carcinogenicity [112, 114]. Some PAHs resemble steroid hormones and are lipid soluble, thereby resulting in accumulation in adipose tissue. These PAHs can even transfer across the placental barrier and the fetal blood-brain barrier. There is increasing evidence that prenatal exposure to PAHs results in multiple adverse effects on embryonic development [115-117]. In utero exposure to higher levels of PAHs has been associated with decreased genomic DNA methylation in American and Chinese cohorts $[118,119]$. Prenatal exposure to traffic-related PAHs was also shown to be linked with hypermethylation of the acyl-CoA synthetase long-chain family member 3 (ACSL3) gene, which impacts asthma pathogenesis in umbilical cord blood of newborns [120] (Table 1).

\section{Other air pollution}

Pregnant women living near major roads may be easily affected by traffic-related air pollution and have been reported to show decreased DNA methylation in the long interspersed nuclear element 1 (LINE-1) gene in placenta tissue [121]. Aberrant DNA methylation patterns have been found in mitochondria-related and antioxidant defense-related genes of neonates who were prenatally exposed to $\mathrm{NO}_{2}$ [122]. In utero exposure to diesel exhaust has been associated with altered methylation of genes that are implicated in cardiovascular-related diseases and substance metabolism [123] (Table 1).

\section{Endocrine-disrupting chemicals}

Endocrine-disrupting chemicals (EDCs) are a class of chemical compounds widespread in the environment
[124]. EDCs are exogeneous synthetic or natural chemicals including phthalates (plastic-softening chemicals), polychlorinated biphenyls, pesticides, and dioxin class compounds, which exhibit hormone-like activity and can disrupt endocrine function by modifying, blocking, or mimicking the actions of endogenous hormones [15, 125127]. There is increasing evidence that has suggested that prenatal exposure to certain EDCs can cause long-term health outcomes including cardiovascular disease, diabetes, infertility, and cancer [128-130]. Because the developing organism is extremely sensitive to hormone analogue [127]. These effects are also correlated with disruption in epigenetic programming [11, 131-133].

\section{Bisphenol A}

Bisphenol A (BPA) is an EDC of specific concern because of its high production and ubiquitous use in the manufacture of polycarbonate plastics in modern society [134]. The data have shown that BPA can be detected in $95 \%$ of human urine samples suggesting its widespread use or exposure [135]. Like particulate matter, BPA can also transfer across the placenta and accumulate in the fetus [136]. In utero exposure to BPA is associated with altered reproductive function, metabolic disorders and hormone-associated tumors such as breast and prostate cancer [137]. A study on mice showed that abnormal methylation patterns resulting from prenatally BPA exposure were established before germ layer differentiation in the embryonic stem cells [11], which may partially explain substantially adverse outcomes of BPA exposure [138-141]. Moreover, compelling evidence has been presented that offspring phenotype was also changed by stably altering the epigenome in a prenatally BPA-exposed mouse model [11]. Interestingly, altered miRNA expression was observed in in utero BPA-exposed sheep [142]. Gene-specific analysis of DNA methylation in humans found that altered methylation patterns of the placenta and the fetal liver and kidney were associated with prenatal exposure to BPA $[114,143,144]$. The genes catechol-O-methyltransferase (COMT) and sulfotransferase 2A1 (SULT2A1) are responsible for encoding two xenobiotic-metabolizing enzymes, and increased methylation at the promoters of these two genes has been revealed in BPA-exposed human fetal liver [145]. It is worth noting that perinatal exposure to environmentally relevant doses of BPA has also shown a transgenerational inheritance of male infertility through epigenome dysregulation in the male germ line [146-148] (Table 2).

\section{Vinclozolin}

Vinclozolin is a systemic fungicide commonly used on fruit and vegetable planting and in the wine industry [149]. Researchers used vinclozolin as an EDC model to 
Table 2 Summary of studies reporting associations between prenatal exposure to EDCs and epigenetic alterations

\begin{tabular}{|c|c|c|c|c|c|}
\hline \multicolumn{2}{|c|}{ Chemical } & Model & Exposure stage & Epigenetic change & Ref. \\
\hline \multirow{10}{*}{\multicolumn{2}{|c|}{ Bisphenol A }} & Mouse & In utero & Increased $E Z H$ gene expression in the mammary gland & [138] \\
\hline & & $\begin{array}{l}\text { Human and } \\
\text { mouse }\end{array}$ & Perinatal & Differential DNA methylation in repetitive DNA & [141] \\
\hline & & Human & In utero & Altered genome-wide DNA methylation in fetal liver & [144] \\
\hline & & Human & 1st to 2nd trimester & $\begin{array}{l}\text { Increased site-specific methylation at COMT and SULT2A1 promoters } \\
\text { in fetal liver }\end{array}$ & [145] \\
\hline & & Mouse & $\begin{array}{l}\text { Preconception to } \\
\text { weaning }\end{array}$ & $\begin{array}{l}\text { Hypomethylation and increased expression of the } A^{v y} \text { gene in agouti } \\
\text { mouse model }\end{array}$ & [11] \\
\hline & & Mouse & In utero & Decreased methylation in Hoxa10 gene promoter & [139] \\
\hline & & Rat & Perinatal & Modified hepatic DNA methylation & [140] \\
\hline & & Sheep & Prenatal & Altered microRNA expression & [142] \\
\hline & & Mouse & In utero & Both hyper- and hypomethylation at the promoter-associated CGls & [132] \\
\hline & & Human & In utero & Positively associated with global methylation for the placenta & [143] \\
\hline \multirow{4}{*}{\multicolumn{2}{|c|}{ Vinclozolin }} & Mouse & In utero & $\begin{array}{l}\text { Decreased methylation in } \mathrm{H} 19 \text { and Gt/2; increased methylation in Peg1, } \\
\text { Snrpn, and Peg3 }\end{array}$ & [151] \\
\hline & & Rat & In utero & Altered epigenetic modification in the male germ line & [150] \\
\hline & & Rat & In utero & Altered methylation in sperm promoter epigenome of F3 generation & [152] \\
\hline & & Mouse & In utero & $\begin{array}{l}\text { Epigenetic transgenerational inheritance of modifications in the mouse } \\
\text { sperm epigenome }\end{array}$ & [124] \\
\hline \multirow{2}{*}{\multicolumn{2}{|c|}{ POPs Dioxin }} & Mouse & In utero & Increased methylation in Igf2r gene in muscle and liver & [175] \\
\hline & & Mouse & Preimplantation & Altered methylation status of imprinted genes H19 and Igf2 & [176] \\
\hline \multirow{3}{*}{\multicolumn{2}{|c|}{ Diethylstilbestrol }} & Mouse & In utero & Increased $E Z H$ gene expression in the mammary gland & [138] \\
\hline & & Mouse & In utero & Hypermethylation and long-term altered expression of the Hoxa10 gene & [177] \\
\hline & & Mouse & Neonatal & Hypomethylation in Exon-4 of c-fos & [178] \\
\hline \multirow{2}{*}{\multicolumn{2}{|c|}{ Methoxychlor }} & Mouse & In utero & $\begin{array}{l}\text { Altered methylation in } \mathrm{H} 19 \text { and Gt12 and increased methylation in Peg1, } \\
\text { Snrpn, and Peg3 }\end{array}$ & [151] \\
\hline & & Rat & In utero & Hypermethylation in the $E R \beta$ promoter regions & [179] \\
\hline \multirow{3}{*}{\multicolumn{2}{|c|}{ PBDEs }} & Human & Prenatal & DNA hypomethylation of Alu and LINE-1 in fetal blood & [168] \\
\hline & & Human & Maternal & Hypomethylation of TNF- $a$ in core blood & [169] \\
\hline & & Human & In utero & Hypomethylation of IGF2 and $\mathrm{NR3C1}$ in placenta & $\begin{array}{l}{[170,} \\
171]\end{array}$ \\
\hline \multirow{2}{*}{\multicolumn{2}{|c|}{ PFOAs }} & Human & Prenatal & Hypomethylation in sperm cells & $\begin{array}{l}{[173,} \\
174]\end{array}$ \\
\hline & & Human & Prenatal & Global and IGF2 hypomethylation in cord blood & $\begin{array}{l}{[95,} \\
172]\end{array}$ \\
\hline
\end{tabular}

investigate epigenetic transgenerational inheritance of disease because of its anti-androgenic activity leading to spermatogenic defects, breast and prostate diseases, and even abnormal immune function at a high frequency (up to 90\%) [1, 150-152]. Although female rat exposure to vinclozolin during gestation resulted in infertility in male offspring, the different timings of exposure may have different outcomes. Exposure during embryonic day (E) 8 to E 14, which is the period of germ line epigenetic programming, can reduce the spermatogenic capacity of male rats in four subsequent generations [131, 153], whereas vinclozolin exposure in later gestation (E 15-E 20) had no effect on fertility of adult males [154, 155]. Thus, exposure of male rats to vinclozolin in the early stage of embryogenesis can cause increased rates of infertility in adulthood and such effects can pass through four generations. Investigation of the molecular mechanisms of the aforementioned transgenerational phenomenon revealed that developmental exposure to vinclozolin substantially impacts reprogramming of the male germ line and induces aberrant methylation patterns which can be stably transmitted through multiple generations [156]. Differential DNA methylation identification in the F3 generation sperm epigenome 
could be used as epigenetic biomarkers for transgenerational influence assessments [124] (Table 2).

\section{Persistent organic pollutants}

Persistent organic pollutants (POPs) are a class of man-made organic (carbon-based) chemicals that remain for long periods of time after their introduction into the environment [157]. These chemicals include dichloro-diphenyl-trichloroethane (DDT), dichlorodiphenyl-dichloroethylene (DDE), polychlorinated biphenyls (PCBs), and 2,3,7,8-tetrachlorodibenzo-p-dioxin (TCDD), as well as perfluorooctanoic acid (PFOA), polybrominated diphenyl ethers (PBDEs), and dioxins [114, 157]. Certain POPs have been shown to have endocrine-disrupting effects such as estrogenic and anti-progestins of DDT, anti-estrogenic of dioxins and PCBs, anti-androgenic of DDT, and anti-thyroid of PCBs and dioxins (https://www.who.int/ceh/capacity/POPs. pdf). Accumulating evidence indicates that prenatal POPs exposures result in adverse mental and physical development [158-161], visual recognition memory abnormity [162], neurodevelopmental delay [163], reproductive problems [164, 165], obesity [166], and immune diseases [167] in the later life of offspring. Moreover, such adverse health effects from prenatal exposure to POPs are associated with epigenetic dysregulation, for instance, DNA hypomethylation of repeat elements (Alu (Arthrobacter luteus) and LINE-1) in fetal blood with exposure to DDT, DDE, and PBDEs [168]; hypomethylation of tumor necrosis factor alpha (TNF- $\alpha), I G F 2$, and nuclear receptor subfamily 3 group $C$ member 1 (NR3C1) in core blood and placenta with exposure to PBDEs [169-171]; global and IGF2 hypomethylation in sperm cells and cord blood samples with exposure to PFOA [95, 172-174]; altered DNA methylation in the $H 19, I G F 2$, and $I G F 2 r$ genes with exposure to dioxin $[175,176]$; hypermethylation of the Hoxa10 gene, hypomethylation in the Exon-4 of c-fos gene, and increased $E Z H$ gene expression with exposure to diethylstilbestrol $[138,177,178]$; and increased methylation in the Peg1, Snrpn, Peg3, and ER $\beta$ genes with exposure to methoxychlor [151, 179]. In addition, certain POPs have been shown to promote epigenetic transgenerational inheritance of disease susceptibility $[148,180]$ (Table 2).

\section{Heavy metals}

Heavy metals refer to metals with a density that exceeds a certain value $\left(5 \mathrm{~g} / \mathrm{cm}^{3}\right)$ and have been used by humans in various areas for thousands of years [181]. Heavy metals including arsenic, cadmium, lead, and mercury are another common type of pollutant widely distributed in modern environments, such as various industrial, agricultural, medical, and domestic fields. The consumption of contaminated water or food is a common source of chronic, but low-level arsenic and cadmium exposure [182, 183]. Pesticide manufacturing is another common source of arsenic exposure [184], and smokers tend to have higher cadmium exposure [185]. Lead is often found in lead-contaminated house dust, residential soil, lead-based paints, glazed food containers, and drinking water [186, 187]. Contaminated seafood is considered the main source of mercury intake [188]. In utero exposure to heavy metals is detrimental for the fetus and mainly causes neurological disorders and cancers in the offspring [189]. Mounting evidence has revealed that such adverse outcomes are implicated with perturbation in the epigenome, which is susceptible to external stimulation during embryonic development [190] (Table 3).

\section{Arsenic}

Prenatal arsenic exposure has been shown to be associated with placenta and cord blood DNA methylation alteration in neonates [191-197], possibly in sex- [193, 194, 198] and time-specific [194] manners. For examples, the levels of DNA methylation were shown to increase in male infants but to decrease in female infants born to arsenic-exposed mothers [193, 198]. Arsenic exposure in late gestation showed a much weaker correlation with newborns cord blood DNA methylation than that in early pregnancy [194]. Furthermore, the effects of prenatal arsenic exposure on DNA methylation are not fully consistent in different studies. Some data supported negative correlation between arsenic exposure and methylation [194, 199], while certain studies demonstrated the role of arsenic in hypermethylation [199201]. Collectively, these studies suggest that prenatal exposure to arsenic is believed to alter epigenetic modification and may dysregulate arsenic-related disease development Table 3.

\section{Cadmium}

Cadmium has a long half-life, lasting for decades, and can accumulate in the bones and then release during pregnancy. These features of cadmium magnify its toxicity to pregnant women and fetuses leading to numerous health problems such as reproductive disorders, kidney dysfunction, and certain cancers [202]. It was shown that early pregnancy exposure to cadmium leads to altered DNA methylation at multiple DMRs in offspring in sex- and possibly race/ethnic-specific manners [203]. Methylome-wide association study (MWAS) also demonstrated that prenatal, including periconceptional, and in utero exposure to cadmium resulted in increased methylation of organ development and mineralization-related genes in female offsprings, hypermethylation of cell death-linked genes in male offspring [204], and altered methylation patterns in leukocytes [205] and the placenta [206], as well as hypomethylation 
Table 3 Summary of studies reporting associations between prenatal exposure to heavy metal and epigenetic alterations

\begin{tabular}{|c|c|c|c|}
\hline Heavy metal & Exposure stage & Epigenetic change & Ref. \\
\hline \multirow[t]{4}{*}{ Arsenic } & In utero & Altered DNA methylation status of specific genes in the placenta & [191] \\
\hline & Prenatal & Altered DNA methylation in artery and placenta & [199] \\
\hline & Prenatal & Altered DNA methylation in newborn cord blood & {$[192,193,196,197]$} \\
\hline & Early pregnancy & Decreased DNA methylation in cord blood & [194] \\
\hline \multirow[t]{5}{*}{ Cadmium } & Prenatal & Differentially methylated CpG sites & [208] \\
\hline & Early pregnancy & $\begin{array}{l}\text { Altered DNA methylation at multiple DMRs in offspring with sex and possibly } \\
\text { race/ethnic-specific effects }\end{array}$ & [203] \\
\hline & Maternal & Decreased DNA methylation levels in placental $P C D H A C 1$ promoter & [206] \\
\hline & Prenatal & Altered DNA methylation differently in girls and boys & [204] \\
\hline & Maternal & Altered DNA methylation levels in the leukocyte of newborns and their mothers & [205] \\
\hline \multirow[t]{3}{*}{ Mercury } & Prenatal & Increased DNA methylation in umbilical cord blood of infants & [190] \\
\hline & In utero & Hypomethylation of EMID2 gene in placental samples & [230] \\
\hline & Prenatal & Related to DNA methylation at the TCEANC2 region in cord blood samples & [231] \\
\hline \multirow[t]{3}{*}{ Lead } & Prenatal & Hypermethylation at the MEC3 DMR regulatory region & [223] \\
\hline & In utero & Sex-specific trends between $\mathrm{Pb}$ and DNA methylation & {$[222,227,228]$} \\
\hline & Prenatal & Hypomethylation of genomic DNA and Alu and LINE-1 genes in cord blood & [224] \\
\hline Manganese & Prenatal & Altered placental DNA methylation & [229] \\
\hline
\end{tabular}

of $L I N E-1$, which is hypermethylated in normal tissues [207] and peripheral blood. Another epigenome-wide association study of two US birth cohorts showed that prenatal cadmium exposure was associated with differentially methylated CpG sites, which were involved in inflammatory signaling and cell growth as well as birth weight [208]. Additionally, prericonceptional exposure to cadmium was found inversely associated with DNMT expression [207] (Table 3).

\section{Lead}

Lead is a common pollutant with no safe level of exposure and no beneficial biological role [209]. Likewise, lead accumulates in bone and has a half-life of about three decades [210]. Lead can elevate levels of homocysteine, disrupt the methionine-homocysteine cycle [211, 212], and reprogram the expression of epigenetic modification-related enzymes [213]. Together, these processes, exposure to lead, especially prenatally, may cause aberrant DNA methylation [214-216] and histome modifications such as histone acetylation [217] in organisms. Such alterations in the epigenome are likely preserved at first $[218,219]$, and then triggered by internal and/or external stimulation in later life resulting in clinical abnormalities such as obesity, cardiometabolic disease, and even Alzheimer's disease (AD) [220-223]. Children who were prenatally exposed to lead displayed hypomethylation of Alu and LINE-1 sequences [224], as well as altered methylation patterns in imprinted genes [222, 223]. Moreover, a study on animals showed that lead exposure can also alter the expression of miRNAs which target certain proteins participating in the pathologic process of disease [225], while no effect was found when exposure occurred in later life. Importantly, maternal lead exposure may leave a methylome fingerprint on her grandchildren, suggesting its potential multigenerational epigenetic inheritance [226]. Moreover, pronounced sex-specific profiles to prenatal lead exposure were also found with respect to DNA methylation alterations [222, 227, 228] (Table 3).

\section{Other heavy metals}

In utero exposure to manganese has been associated with differential methylation in the placenta [229]. DNA methylation changes, which were linked with altered immune profiles or adverse infant neurobehavioral outcomes, were found in the placenta as well as umbilical cord blood in newborns whose mothers had experienced mercury exposure during pregnancy [190, 230, 231] (Table 3).

\section{The characteristics of prenatal exposure-related epigenetic dysregulation The portal function of the placenta}

Exposure-related alterations in fetal development result in potential changes in metabolism and development [232]. As a transient organ, the placenta serves as a gatekeeper between the fetal and maternal circulation throughout pregnancy, ensuring survival of the fetus [61, 73]. It not only plays crucial roles in mediating the transfer of oxygen, nutrient substance, and hormones from mother to fetus [233], but also can produce growth factors and 
hormones and mediate fetal immune tolerance [61]. Adverse environmental factors during embryonic development may disrupt all placental functions of transportation, metabolism, protection, and endocrine, and such effects can be encoded in the placental methylome [234, 235], which will provide a unique footprint of exposures [65]. Hence, the placenta exhibits considerable plasticity, especially a distinctive DNA methylome [232, 236, 237]. However, if placental capacity to adapt is exceeded, fetal growth and development may be compromised directly [61]. Moreover, certain environmental toxicants can cross the placenta causing distorted fetal reprogramming and disease pathogenesis in later life [238].

\section{Transgenerational inheritance}

Transgenerational inheritance is often used rather broadly to describe non-DNA sequence-based inheritance that can be transmitted from one generation of an organism to the next $[239,240]$. The F3 generation (the offspring of the F2 generation) is the first generation that exhibits transgenerational inheritance as both the $\mathrm{F} 1$ (the offspring of the parent generation) embryo and the F2 (the offspring of the F1 generation) germline involve direct exposure when an F0 (the parent generation) gestating female is exposed to an environmental factor [241-244]. Of great concern is that prenatal environmental exposure-induced epigenetic modifications may pass across subsequent generations through the germ line, leading to predisposition to diseases or disorders in the offspring $[1,30,245]$. Guerrero-Bosagna et al. proposed plausible molecular mechanisms/conditions for environment-induced epigenetic transgenerational inheritance including stepwise processes: first, exposure during gametogenesis; second, epigenetic insults in PGCs; third, imprinting-like programming in the germ line, especially in the male germ line, escaping reprogramming during early embryonic development; fourth, altered epigenome in the germ line transmitted to subsequent generations in cells and tissues; and finally, increased susceptibility to related diseases in postnatal life [124]. Epimutations mainly on DNA methylation resulting from F0 generation gestating female exposure to EDCs have previously demonstrated transgenerational inheritance through the male germ line $[242,246,247]$. It should be pointed out that sperm epimutations can magnify with increasing passages [242].

\section{Time/age-specific susceptibilities}

The distinct time windows, i.e., preconception, early gestation, infancy, and old age, are characterized by age-specific disease susceptibility [248]. As the epigenome is undergoing dynamic change and is vulnerable, the periods of early fetal development and the gamete formation are thought to be most susceptible to environmental stimulations. Human pregnancy has three trimesters: trimester 1 , from 1 to 13 weeks; trimester 2 , from 14 to 26 weeks; and trimester 3 , from 27 weeks to delivery. Thus, the first trimester from fertilization to implantation undergoing epigenetic reprogramming that is highly sensitive to environmental stimuli is considered the most important developmental stage and can decide later-life disease susceptibility in the offspring.

\section{Sex-specific response/profile}

Dynamic processes of epigenetic reprogramming in male and female genomes exhibit dramatic differences $[14,20]$ and this includes changes to the epigenome in their embryonic stem cells [249]. As aforementioned, male fetus has been observed a higher susceptibility to maternal smoking than the female [110]. Developmental exposure to vinclozolin [156] and BPA [146-148] has been shown a transgenerational inheritance of aberrant methylation patterns through the male germ line. Moreover, early pregnancy exposure to cadmium [203, 204] and lead [222, 227, 228 ] resulted in altered DNA methylation in offspring in a sex-specific manner.

\section{The potential mechanisms of prenatal exposure-related epigenetic dysregulation Oxidative stress}

Taking PM as an example, inhaled particles may first translocate from the maternal lung into the bloodstream, then pass through the placental barrier and induce oxidative stress [122, 250, 251]. DNA damage induced by oxidative stress has been associated with differential methylation in several candidate genes in response to prenatal exposures $[120,252]$. DNA damage may block the binding of DNMTs, whose dysfunction is lethal to developing embryos [253], to the DNA template thereby causing hypomethylation [254]. Well-documented evidence demonstrates that DNA hypomethylation can induce genomic and chromosomal instability [255-257], and has been linked with abnormal embryonic development [258] such as spina bifida [259] and low birth weight [260] of newborns (Fig. 2).

\section{Transcription factor occupancy}

For gene-specific DNA methylation patterns, the transcription factor occupancy theory proposes that the blocking approach to DNA methylation machinery may occur due to the presence of transcription factors on gene regulatory region, or vice versa [261, 262]. In a similar manner, if environmental chemicals trigger the presence or absence of transcription factors on a gene regulatory region, this may result in site-specific methylation patterns [114] (Fig. 2).

\section{The perturbation of related enzymes}

For genome-wide patterns of methylation, it has been shown that environmental cues may change the function 


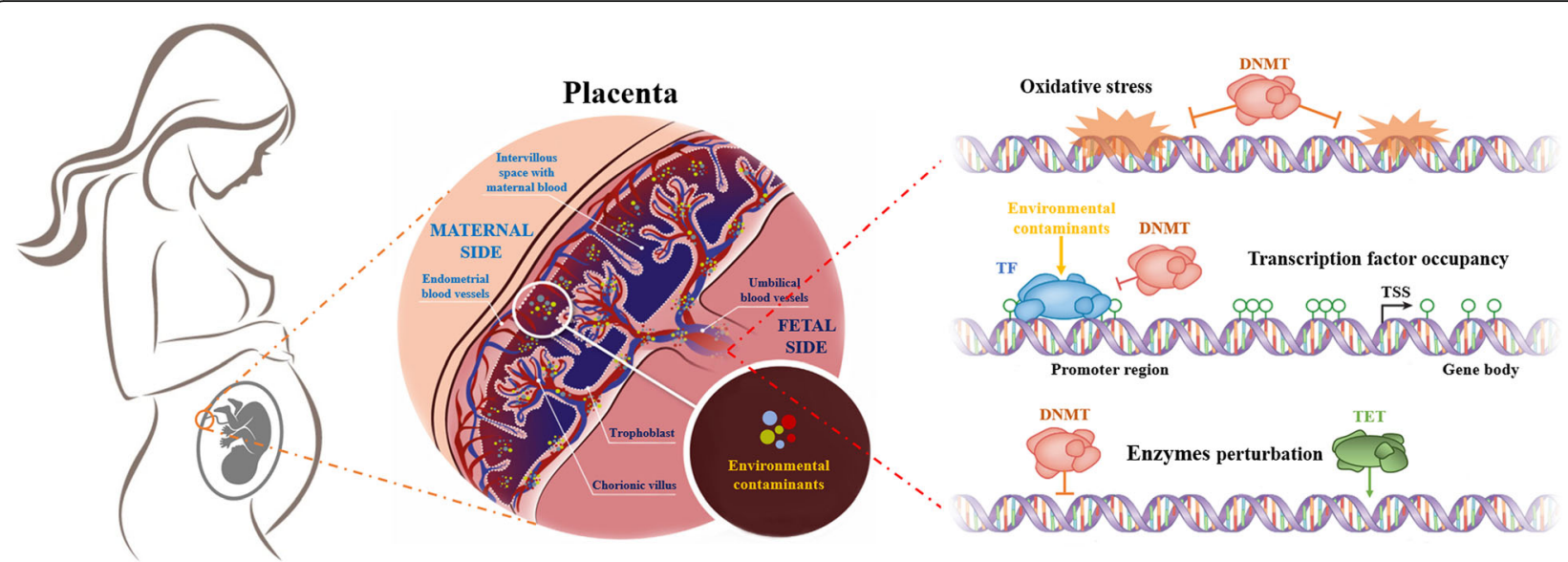

Fig. 2 Diagram of the potential mechanisms of contaminant-induced epigenetic dysregulation. Environmental contaminants can be absorbed into the maternal blood through breathing, ingestion, drinking, or contact. Subsequently, certain environmental toxicants can pass the placental barrier and accumulate in the fetal bloodstream, causing epigenetic dysregulation through three potential ways: DNA oxidative damage may block the binding of DNA methyltransferase (DNMT) to the DNA template; activation of transcription factors (TFs) can inhibit DNMTs from accessing the DNA, resulting in gene-specific hypomethylation; interfering activity of DNMT or/and ten-eleven translocation (TET) enzyme families, leading to genomic methylation dysregulation. Adapted and used with permission from Martin et al. [114] and Luyten et al. [232]. Abbreviations: DNMT, DNA methyltransferase; TSS, transcription start site; TF, transcription factor; TET, ten-eleven translocation

of DNMT or/and ten-eleven translocation (TET) enzyme families as well as the availability of $S$-adenosylmethionine (SAM) to DNA [114] leading to genomic hypomethylation or hypermethylation (Fig. 2).

Obviously, epigenetic modifications are potentially reversible, and a deeper understanding of the characteristics and mechanisms implicated in adverse outcomes of prenatal environmental stimulations will likely promote exploration of new effective therapeutic methods targeting anomalous epigenetic markers. Until the present, some histone deacetylase (HDAC) inhibitors and DNMT inhibitors, which are approved by FDA, have been used in epigenetic pharmacological therapies, providing clinical benefits through inhibiting HDACs or DNMTs [15]. Nevertheless, recent studies elucidate that certain bioactive compounds in "epigenetics diets" may act as DNMT inhibitors, HDAC inhibitors, or/and miRNA regulators that influence the epigenetic profile and play a potential protective role against environmental pollution.

\section{Epigenetics diets and their roles on epigenetic regulation}

Early-life dietary nutrition can profoundly affect developmental fate through the altered epigenome [35]. Female larvae can develop into queen bees or sterile worker bees in the presence or absence of royal jelly, which is the most typical example of nutrition epigenetics [263]. However, the proportion of larvae developing into queen bees would increase with the knockdown of DNMT3, suggesting the bridge role, at least in part, through DNA methylation between early-life royal jelly consumption and adult phenotype [264]. Early-life supplementation of certain foods can also have detrimental effects on the developing fetus. Results from a meta-analysis showed that prenatal alcohol exposure may disturb protein synthesis, mRNA splicing, and chromatin regulation in rodent embryos [265]. Of great interest is that a number of bioactive dietary components act to modify the epigenome through consumption of so called "epigenetics diets" [30]. Here, we detail epigenetic diets and their roles in epigenome modification (Table 4).

\section{Polyphenols}

Polyphenols are widely distributed secondary metabolites from plant origin, especially fruits and vegetables [266]. Accumulating literature indicates that these phytochemicals have antioxidant, anti-inflammatory, and other beneficial effects on human health [267]. Many polyphenols have shown properties in regulation of epigenetics, such as DNMT inhibition by resveratrol in grapes [268], HDAC inhibition by sulforaphane in broccoli [269], histone acetyltransferase (HAT) inhibition by (-)-epigallocatechin-3-gallate (EGCG) in green tea [270] as well as miRNA regulation by genistein in soybean [271].

\section{EGCG}

Catechins are the most abundant polyphenolic compounds in green tea, among which EGCG accounts for more than $50 \%$ of the active compounds [272, 273]. Apart from its known roles in DNA methylation [274276], EGCG also acts as a histone modifier and miRNA modulator. Compared with other green tea polyphenols, 
EGCG exhibits the most potent HAT inhibitor properties targeting various HAT enzymes including p300, CBP, Tip60, and PCAF [270]. Our study demonstrated that combined with SFN, EGCG can remodel chromatin structure by histone modification as well as change methylation patterns in the $E R \alpha$ promoter, thereby reactivating $E R \alpha$ expression and then re-sensitizing anti-hormone (tamoxifen) treatment in ER-negative breast cancer [276]. In another study, EGCG has shown to affect Polycomb-group (PcG) proteins which can compact chromatin and silence cancer-related genes through regulating histone methylation and acetylation [277]. Additionally, EGCG has also been found to modulate miRNA expression in human nasopharyngeal carcinoma CNE2 cells [278], osteoarthritis chondrocytes [279], osteosarcoma cells [280], and spontaneously hypertensive rat [281] (Table 4).

\section{Resveratrol}

Resveratrol (RSV) is a natural polyphenolic compound and is often found in peanuts, berries, and grape species, especially in the skin of red grapes [282]. RSV exhibits antioxidant, anti-inflammatory, antiangiogenic, and anticancer properties through epigenetic regulations via its abilities of DNMT [268, 283-286] and HDAC inhibition [283, 285, 287-289]. Sirtuin 1(SIRT1) is a NAD +-dependent histone deacetylase which deacetylates proteins that contribute to oxidative stress, aging, obesity, and tumors [290]. Importantly, SIRT1 is also involved in the regulation of DNMT1 activity [291]. A body of investigations indicates that RSV is associated with SIRT1 activation in various metabolic pathways [292-298]. Moreover, new studies suggest that RSV acts as a miRNA regulator in thrombus resolution [299], type 2 diabetes (T2D) treatment [300], clinical pancreatic ductal adenocarcinoma (PDAC) prevention [301], osteoarthritis therapy [302], and anti-inflammation [303] (Table 4).

\section{Genistein}

Genistein (GE) is a phytoestrogen and the major isoflavone primarily present in soy [304]. GE has been shown to exhibit health beneficial properties including inhibition of obesity, insulin resistance, and metabolic diseases, preventing inflammation and multiple cancers [305]. As aforementioned, polyphenols such as GE also exhibit striking effects on DNA methylation [285, 306$309]$ and histone modification [285, 306, 309, 310]. It was shown that some tumor suppressor-related genes, such as $p 16, p 21, R A R \beta, C C N D 2$, GSTP1, MGMT, and $B T G 3$, were reactivated by GE-mediated promoter hypomethylation or/and histone hyperacetylation [311-316]. In our preliminary study, GE was also found to repress human telomerase reverse transcriptase (hTERT), which is the catalytic subunit of human telomerase, by locus-specific hypomethylation as well as chromatin structure remodeling of the $h T E R T$ promoter in breast cancer models [317]. Furthermore, GE may act as a miRNA modulator in breast, prostate, colorectal, and renal cancer prevention [271, 318-321] (Table 4).

\section{Other polyphenols}

Other polyphenols are also implicated in various health beneficial effects in human and animals through, at least in part, their properties in DNA inhibition, HDAC inhibition, HAT activation, and miRNA modulation such as kaempferol [322-324] and phloretin [325] in apple; apigenin [326, 327] and luteolin [327-330] in celery; hesperidin [331] and quercetin [332-334] in citrus; caffeic acid [335, 336] and chlorogenic acid [335] in coffee; allyl mercaptan [337] and diallyl disulfide [338-340] in garlic; anthocyanin $[325,341,342]$, piceatannol [333, $343,344]$, and procyanidin [283, 342, 345-348] in grape; theophylline [349, 350] in green tea; biochanin A [350], daidzein [351], and equol [352] in soy; and curcumin in turmeric [353-357] (Table 4).

\section{Vitamins \\ Vitamin C}

Vitamin C (L-ascorbic acid) is known for its essential role in collagen crosslinking [358]; thus, its severe deficiency may cause scurvy [359]. Recent investigations have revealed functions of vitamin $C$ in epigenetic regulations. Ascorbate, the form of vitamin $\mathrm{C}$ existing under physiological $\mathrm{pH}$ conditions, is found to be involved in active DNA demethylation [360-366] and histone demethylation [360, 367-369] as well as epigenome reprogramming [358] in a cofactor manner. TET dioxygenase, catalyzing the oxidation of $5 \mathrm{mC}$ into 5 -carboxylcytosine $(5 \mathrm{caC})$ that are ultimately replaced by unmodified cytosine, has three cofactors, among which ascorbate is recently discovered and verified. The Jumonji $\mathrm{C}$ (JmjC)-domain-containing histone demethylases (JHDMs) including JHDM1A, 1B, and 3A also need ascorbate as a cofactor for histone demethylation [369371]. Furthermore, a recent study revealed a specific role for vitamin $\mathrm{C}$ in $\mathrm{H} 3 \mathrm{~K} 9 \mathrm{me} 2$ demethylation in mouse embryonic stem cells [368] (Table 4).

\section{Vitamin D}

The discovery of the calcitriol receptor, commonly known as the vitamin D receptor (VDR), gradually uncovers the roles of vitamin $\mathrm{D}$ in regulating transcriptional responses and underlying epigenetic mechanisms [372]. VDR is a member of transcription factors. The active form of vitamin D can bind to calcitriol [373], while VDR mainly binds at loci of open chromatin. Upon treating human leukemia cell lines, THP-1, with 
Table 4 Epigenetic diets and their properties in epigenetic regulation

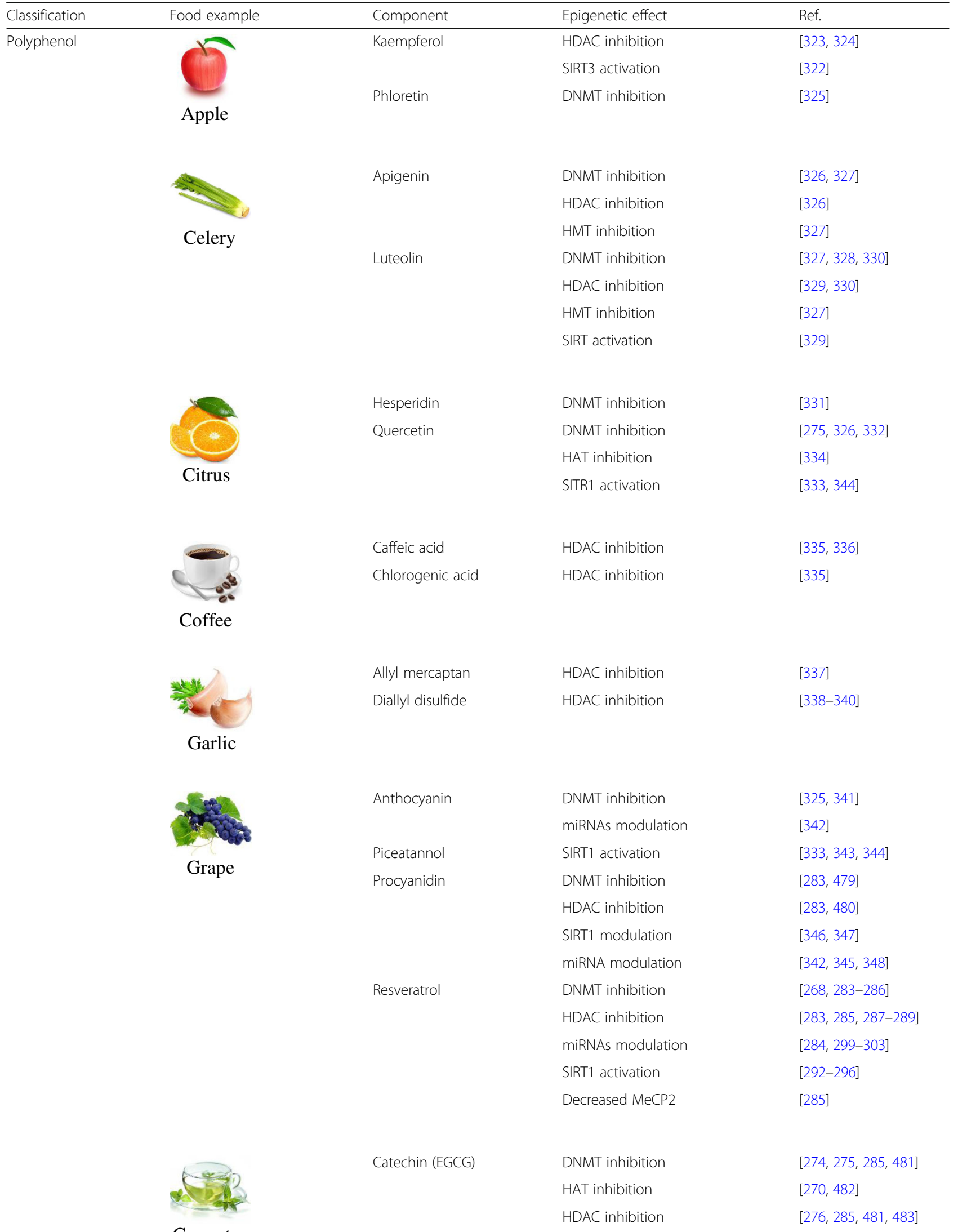


Table 4 Epigenetic diets and their properties in epigenetic regulation (Continued)

\begin{tabular}{|c|c|c|c|c|}
\hline Classification & Food example & Component & Epigenetic effect & Ref. \\
\hline & & & Decreased MeCP2 & {$[285]$} \\
\hline & & & miRNAs modulation & {$[278,279,281]$} \\
\hline & & Theophylline & HDAC activation & {$[349,350]$} \\
\hline & & Biochanin A & DNMT inhibition & [350] \\
\hline & & Daidzein & DNMT inhibition & [351] \\
\hline & Soy & Equol & Demethylation of BRCAs & [352] \\
\hline & & Genistein & DNMT inhibition & {$[285,306-309]$} \\
\hline & & & Decreased MeCP2 & [285] \\
\hline & & & HDAC inhibition & {$[285,306,309]$} \\
\hline & & & HAT activation & {$[311,313]$} \\
\hline & & & miRNAs modulation & {$[271,318-321]$} \\
\hline & & Curcumin & DNMT inhibition & {$[285,353,484,485]$} \\
\hline & & & Decreased MeCP2 & [285] \\
\hline & & & HAT inhibition & {$[354]$} \\
\hline & Turmeric & & HDAC inhibition & {$[285,355,356]$} \\
\hline & & & miRNAs modulation & {$[357,486-489]$} \\
\hline \multirow[t]{14}{*}{ Vitamin } & & Folate & One-carbon metabolism & {$[386,490,491]$} \\
\hline & & & HMT regulation & [491] \\
\hline & & & Epigenome regulation & [492] \\
\hline & & & miRNAs modulation & {$[405,493-495]$} \\
\hline & & Vitamin C & DNA demethylation & [360-366] \\
\hline & & & Histone demethylation & [367-370] \\
\hline & & & Epigenome regulation & {$[358]$} \\
\hline & & Vitamin D & DNA methylation & {$[375-379,468,469,496]$} \\
\hline & & & Histone modification & {$[372,374,380,381]$} \\
\hline & & & Epigenome regulation & {$[372,470]$} \\
\hline & & & miRNAs modulation & [497-499] \\
\hline & & Choline & DNA methylation & [393-398, 401-404] \\
\hline & & & Histone methylation & {$[405]$} \\
\hline & & & miRNAs modulation & {$[405-407]$} \\
\hline \multirow[t]{5}{*}{ Other } & & Isothiocyanate & HDAC inhibition & [419-422] \\
\hline & & Sulforaphane & HDAC inhibition & {$[269,276,409-412]$} \\
\hline & & & DNMT inhibition & {$[276,414,415]$} \\
\hline & Broccoli & & miRNAs modulation & {$[414,416-418]$} \\
\hline & & Withaferin A & DNMT inhibition & {$[285,411]$} \\
\hline
\end{tabular}


Table 4 Epigenetic diets and their properties in epigenetic regulation (Continued)

\begin{tabular}{llll}
\hline Classification & Food example & Component & Ref. \\
\hline & & HDAC inhibition & {$[269,285,411]$} \\
{$[269]$} & {$[269]$} \\
{$[500]$} & HMT inhibition & HAT activation & {$[436,437,439-444]$} \\
India winter & miRNAs modulation & {$[436,438]$} \\
& Serry & DNA methylation & {$[436]$} \\
Konjac powder & Histone modification & DNMT inhibition & HDAC inhibition \\
\hline
\end{tabular}

1,25-dihydroxyvitamin $\mathrm{D}_{3}(1,25-\mathrm{D} 3)$, a VDR ligand, chromatin accessibility substantially increased [374]. Primary roles of vitamin $\mathrm{D}$ on epigenetic regulation are associated with DNA demethylation and histone acetylation. There is evidence showing that vitamin $\mathrm{D}$ treatment is negatively correlated with promoter methylation status of the adenomatous polyposis $(A P C)$ gene, a tumor suppressor gene in colorectal cancer [375], as well as dickkopf-related protein 1 (DKK1) [376], E-cadherin [377], PDZ-LIM domain-containing protein 2 (PDLIM2) [378] and $p 21$ [379]. In in vitro experiments, 1,25-D3 treatments have been shown to regulate gene expression through histone acetylation and methylation, such as H3K27ac [374], H3K9 di-methylation [380], and H3K9ac [381], as well as affecting the expression of a series of JHNMs [372]. Recent studies have revealed vitamin D anticancer properties through miRNA modulation (reviewed in [382]) (Table 4).

\section{Folate}

Folate or folic acid, also known as pteroylglutamic acid, is a water-soluble B-complex vitamin and usually exists in green vegetables and animal liver. Biologically, folate together with vitamin B12 (VB12) plays a crucial role in the one-carbon metabolism and embryonic development. In this context, low dietary intakes of folate are associated with various clinical symptoms, especially neurological and developmental disorders [383]. As a methyl donor, folate takes part in the methionine cycle and ultimately offers methyl for DNA and protein methylation, thereby changing chromatin structure and modulating gene expression [384]. Although DNA hypomethylation resulting from poor folate status is linked with inappropriate expression of cancer-related genes [385], it should be pointed that folate depletion can cause both hypo- and hypermethylation of DNA [386].
Furthermore, folic acid supplementation has been shown to reduce the risk of cancer [387, 388] through regulation of DNA methylation patterns [389, 390] (Table 4).

\section{Choline}

Like folate, choline is one of the precursors that can be converted to SAM, the universal methyl donor for numerous methylation processes including the methylation of cytosine in DNA, lysine in histones, and adenine in RNA as well as other molecules [391, 392]. Feeding pregnant methylation-indicator-mice a diet high in choline and other methyl donors resulted in offspring born with a brown coat and kinks in their tails through altering methylation status of $A^{v y}[393,394]$ and Axin (Fu) [395] genes, respectively. Several other examples have also demonstrated that dietary supplementation with choline changed methylation levels of CpG sites in the genes IGF2, Srebf2, Agpat3, Esr1, Fasn, and Cdkn3 [396398]. On the other hand, upon treatment of pregnant rats with choline-deficient diets, IGF2 was hypermethylated through upregulating DNMT1 expression [399]. In humans, the maternal supply of choline is essential for fetal and infant development, especially for brain development. Thus, extra choline is needed for pregnant and breast-fed women. Additionally, choline has a role in reducing human tumor progression. As evidence of this, Sun et al. found that low choline intake increases overall risk for lung cancer (30\%), nasopharyngeal cancer (58\%), and breast cancer $(60 \%)$, whereas cancer incidence reduces by $11 \%$ after choline $(100 \mathrm{mg} /$ day $)$ supplementation [400]. Studies have been well documented that choline can inhibit cancer development via modifying epigenetic markers. Choline-deficient diets result in hypomethylation of oncogene (e.g., $c-m y c)$ [401], but also hypermethylation of several tumor suppressor genes (e.g., p16, p53, and Cx26) [402-404]. Moreover, dietary 
choline concentration also affects histone methylation [405] and miRNA expression [405-407] (Table 4).

\section{Other epigenetics diets Isothiocyanates}

Isothiocyanates (ITCs) are generated by the enzymic hydrolysis of glucosinolates in plants. Sulforaphane (SFN) is an isothiocyanate that is present naturally in cruciferous vegetables such as broccoli, kale, cabbage, radish, and mustard [30, 408]. Increasing interest has focused on SFN-mediated chemoprevention due to its proven potent activity in HDAC inhibition [269, 409-412], which may lead to increased histone acetylation genome-wide as well as at specific-gene levels as histone acetylation is unequivocally linked with increased propensity for gene transcription [413]. Moreover, SFN has been shown to have properties in DNMT inhibition [276, 414, 415] and miRNA modulation [414, 416-418]. Except SFN, other ITCs [419-422] have also been shown various health beneficial effects in human and animals through their properties in epigenetic modification (Table 4).

\section{Withaferin A}

Withaferin A (WA), the first described withanolide, is a natural steroid lactone derived from Withania somnifera and has been attracting increasing interest because of its multifunctional properties including anti-inflammatory [423, 424], antimetastatic [425], anti-angiogenesis [426], and especially antitumor activity [427-429]. Importantly, WA exerts strong anticancer activity in mammary tumors at pharmacologically achievable concentrations [430]. In a recent study conducted by vel Szic et al., both triple-negative MDA-MB-231 and estrogen receptor-positive MCF-7 cells showed global DNA hypermethylation once treated with WA, and DNA methylation levels in MDA-MB-231 were lower than MCF-7 cells. Meanwhile, methylation perturbation-related specific genes were bidirectional (both hyper- and hypomethylated) and were contrary between these two cell lines. The authors also found that the observed hypermethylation has been linked with decreased H3K4me3 at the PLAU gene promoter [431]. In an earlier in vitro study, however, cells treated with 8 and $10 \mu \mathrm{M}$ WA exerted DNMT inhibition activity [285]. In addition, WA has been associated with a decreased chromatin accessibility at the $I L-6$ gene promoter region [432]. Two studies from our lab also illustrated WA acted as DNMT and HDAC inhibitors in breast cancer cells, and such activities were strengthened once combined with SFN [269, 411] (Table 4).

\section{Selenium}

Selenium (Se) is an essential trace element usually found in cereals, nuts, and vegetables [433], and has different forms including selenocysteine, sodium selenite, and sodium selenide [434]. Se has been received considerable attention for its beneficial effects toward human health such as immunity enhancement and anticarcinogenic action. Adequate selenium intake during pregnancy can also promote successful and healthy pregnancies through protecting against oxidative stress [435]. Nevertheless, mounting investigations have linked its priorities in regulation of epigenetic mechanisms, especially DNA methylation. Treated prostate cancer cells with Se have been shown to reactivate the expression of GSTP1 by upregulating partial promoter DNA methylation levels and $\mathrm{H} 3 \mathrm{~K} 9 \mathrm{ac}$, while inhibiting HDAC activity as well as H3K9 methylation [436]. In addition, Se deficiency resulted in genomic DNA hypomethylation and promoter hypermethylation of $p 16$ and $p 53$ [437]. Furthermore, Miranda et al. found that sodium selenite and methylseleninic acid both can inhibit DNMT1 expression in breast cancer cells. In addition, decreased H3K9me3 and H4K16ac were observed in methylseleninic acid and sodium selenite treated groups, respectively [438]. In mouse and rat studies, diet supplemented with Se resulted in increased DNA methylation in colon tissue [439, 440] and decreased global DNA methylation in liver [441, 442] and in heart [443], as well as increased methylation in the exon-specific locus of Tp53 [442] and promoter regions of two inflammatory-related genes (TLR2 and ICAM1) [444] (Table 4).

A growing body of evidence shows that dietary nutritious and non-nutritious components of vegetables, fruits, nuts, and beverages can regulate epigenetic processes (e.g., covalent modification of DNA, protein and RNA, miRNA modulation, chromatin remodeling) involved in critical life processes of human health such as immune improvement, apoptosis inhibition, and cancer prevention (Table 4). Their potential protective roles against environmental pollution have been attracting increasing attention.

\section{The potential protective roles of prenatal epigenetics diets against environmental pollutants}

It is now clear that prenatal exposure to environmental pollutions induces adverse outcomes of embryonic and postnatal development through epigenetic dysregulation. In a similar manner, parental nutritional exposure may also induce long-term epigenetic perturbation in the offspring, determining the health of descendants throughout lifetime [30, 445, 446]. The former often occurs in a passive situation and leads to severe health issues in humans, whereas nutritional intervention is controllable and often beneficial. Increasing numbers of studies have shown potential properties of dietary compounds in epigenetic pharmacological therapies and chemoprevention. 
As a typical example, studies carried out by Dolinoy et al. demonstrated that a maternal methyl diet and phytoestrogen supplementation counteracted coat color change and hypomethylation in offspring induced by in utero and neonatal exposure to BPA [11], suggesting that maternal nutritional supplementation could be a potential preventive approach to attenuate or negate epigenome dysregulation resulting from environment stimulation. Here, we review the potential possibilities of prenatal nutrition against environmental exposure via epigenetic regulation.

\section{Maternal diets vs. EDCs}

As noted above, BPA is a typical, ubiquitous endocrine-active compound. SAM functions as a universal methyl donor for methylation processes in DNA, protein, and RNA. B vitamins including folic acid, VB6, and VB12, as well as amino acids, such as choline, methionine, and betaine, are classified as methyl donor nutrients as they all either directly or indirectly act as precursors of SAM. In Dolinoy's study [11], they first exposed female mice to $50 \mathrm{mg} / \mathrm{kg}$ BPA diet 2 weeks before mating with Avy/a males and throughout gestation and lactation. A changed coat color was found to be associated with decreased methylation of nine CpG sites of the Agouti gene. Strikingly, BPA-induced DNA hypomethylation in the offspring was negated after female mice were supplemented with methyl donors in their diet (4.3 $\mathrm{mg}$ of folic acid $/ \mathrm{kg}$ diet, $0.53 \mathrm{mg}$ of vitamin B12/ $\mathrm{kg}$ diet, $5 \mathrm{~g}$ of betaine $/ \mathrm{kg}$ diet, $7.97 \mathrm{~g}$ of choline chloride $/ \mathrm{kg}$ diet). Although it is not clear which nutrients specifically played a more critical role in this mixed methyl diet, elevated methylation may reverse hypomethylation on the epigenome caused by EDC, indicating paternal methyl donor supplementation could be a potential nutrition intervention against prenatal EDC exposure. Importantly, shifted coat color distribution brought by a maternal methyl donor diet through hypermethylating-related genes in $\mathrm{A}^{\mathrm{vy}}$ offspring was shown to be inherited through multiple generations [447], suggesting nutrient-reversed BPA-induced epigenome alterations can be transmitted transgenerationally through epigenetic inheritance via germline transmission [146-148]. In addition, dietary vitamin B supplementation appears to attenuate the adverse effects caused by pesticides in paint [448].

Maternal dietary exposure to genistein, which is a plant phytoestrogen primarily present in soy, also has been shown to shift offspring coat color by upregulating genomic methylation [449]. In Dolinoy's study, upon treating virgin a/a female mice with $50 \mathrm{mg} / \mathrm{kg}$ diet of BPA and $250 \mathrm{mg} / \mathrm{kg}$ diet of genistein, BPA-induced hypomethylation in the Agouti gene of offspring was neutralized [11]. As polycarbonate plastics, like BPA, are ubiquitously used in the human population, and soybean products are widely consumed, the ability of genistein to prevent negative environmental toxicant effects via prenatally nutritional intervention has a promising prospect.

\section{Maternal diets vs. smoking}

DNA methylation markers could be potential indicators of paternal smoking as methylation alteration of a series of genes has been shown to link to cigarette use. Among these genes, hypomethylation of $A H R R$, particularly at cg05575921 loci, was often found [104, 450-452]. In a recent study on African-American cohorts, smoking-induced DNA demethylation at $A H R R$ was moderated by increased methylation of methylene tetrahydrofolate reductase (MTHFR), which is a key regulator in methyl metabolism [453]. Consistently, Zhang et al. found that sufficient maternal folate level could partly mitigate the adverse effect of maternal smoking on the epigenome of newborns, as well as on child health [110]. Moreover, Richmond and Joubert contrasted the effects of maternal smoking and one-carbon micronutrient exposures on the DNA methylome in the offspring and found that these two categories of exposure have potential opposite impact on the offspring epigenome and act independently [454].

\section{Maternal diets vs. metabolic syndrome}

Metabolic syndrome (MetS) is a progressive phenotype that is characterized by a series of metabolic disorders such as obesity, hypertension, dyslipidemia, and insulin resistance [30, 455]. As reviewed above, maternal exposure to environmental pollutants has been shown to result in MetS with similar epigenome dysregulation in offspring. It was shown that maternal dietary methyl donors may regulate MetS through epigenetic mechanisms. Wolff et al. revealed that methyl donors supplementation in pregnant $\mathrm{A}^{\mathrm{vy}} / \mathrm{a}$ mice prevented MetS phenotypes in offspring by DNA hypermethylation [393]. In addition, a methyl diet (folate, VB12, betaine, and choline) has been shown to prevent obesity in the same mouse strain [456] through DNA hypermethylation. Similar studies in humans also demonstrated that prenatal folic acid supplementation can reduce MetS incidence in children in rural Nepal [457], while disproportionality of folate and VB12 during gestation leads to insulin resistance and obesity in the offspring [458].

Maternal soybean supplementation also induced locus-specific DNA hypermethylation in $\mathrm{A}^{\mathrm{vy}}$ intracisternal A particle $(I A P)$ retrotransposon of heterozygous viable yellow agouti (Avy/a) offspring, shifting their coat color toward pseudoagouti, meanwhile decreasing obesity incidence in adulthood [449].

\section{Diets vs. ambient fine particles}

Exposure to PM may induce systemic inflammation and oxidative stress through epigenome dysregulation. In a 
recent striking study, investigators demonstrated that B-vitamin supplementation $(2.5 \mathrm{mg} / \mathrm{d}$ folate, $50 \mathrm{mg} / \mathrm{d} \mathrm{VB} 6$ and $1 \mathrm{mg} / \mathrm{d}$ VB12) nearly completely prevented reduced mitochondrial DNA content and decreased DNA methylation through protecting against PM2.5-induced DNA hypomethylation. Meanwhile, these methyl group-supplying nutrients might minimize DNA hypermethylation by interacting with essential enzymes including DNMTs and MTHFR [72]. These findings point out that B vitamins might avert the loss of DNA methylation induced by air pollution, although this study was conducted as a short time $(2 \mathrm{~h})$ exposure with high PM2.5 concentration $\left(250 \mu \mathrm{g} / \mathrm{m}^{3}\right)$ in adults. As Lucock et al. mentioned, a study from Zhong et at. draws attention to the role of B-vitamin in exposomal factors, yet it is still premature to draw a conclusion [459]. Interestingly, Zhong et al. also reported such a vitamin B diet can mitigate the effects of PM2.5 exposure on cardiac autonomic dysfunction and inflammation [460].

\section{Diets vs. heavy mental}

Dietary folic acid supplementation has been shown to prevent, at least in part, the adverse effects caused by environmental contaminant including chromium [461] and arsenic [462, 463]. Wang et al. conducted a study within workers from a chromate production plant and found that global DNA hypomethylation and DNA damages in blood were associated with decreased serum folate, suggesting folic acid supplementation may maintain genome stability and block cancer development in chromate sufferers [461]. Moreover, adequate folate has been shown to modify DNA methylation in peripheral blood leukocytes (PBL) [462] and Alu repetitive elements [463] of arsenic-exposed adults, suggesting a potential protective role of one-carbon metabolism nutrients in arsenic toxicity.

Except one-carbon metabolism nutrients and phytochemicals mentioned above, prenatal vitamin C [464-467], vitamin D [468-471], and certain polyphenols [59, 472-474] supplementation have been shown to maintain organismic normal growth and development, reduce susceptibility to disease, and prolong tumor latency through epigenetic regulation. All these epigenetic agents could be potentially used to counteract environmental toxicant-induced epigenome abnormity. It should be recognized that the investigations of prenatal nutrition intervention targeting environmental insults are still in the exploratory stage and more studies are needed.

\section{Potential considerations of prenatal nutritional intervention against environmental contaminants Windows of intervention}

Early life, including germ cell differentiation and preimplantation of the embryo in the first trimester of humans, and infancy, is susceptible for external environmental stimulation to disrupt epigenome reprogramming. If exposed early, more serious consequences may occur compared with late gestation or adulthood exposures. Similarly, there are optimal windows of nutritional intervention to resist environmental insults. In-depth understanding of the relationship between dynamic change of the epigenome, environmental disturbance, epigenetics diet properties and disease susceptibly may lead to considerable progress in the epigenetic chemoprevention and pharmacological therapies [35].

\section{Global influence of epigenetics agents}

As abovementioned, epigenetics diets usually exhibit global epigenetic modification such as DNMT inhibition and HDAC inhibition. Although numerous findings indicate that early-life nutrition supplementation reduces adverse effects of exposure to epigenetically toxic agents, some concerns are raised because of their potential, unpredictable targets in multiple genes by large-scale epigenetic perturbation, which are still unclear. There is promise that more targeted strategies will be developed and epigenetic therapies would be a powerful choice in clinical practice in the future [15].

\section{Multiple contaminants exposure}

It is noteworthy that humans are often exposed to numerous environmental factors instead of a single contaminant. As detailed previously, most of the investigations only examined epigenome dysregulation caused by a single source of pollution. In developing nutritional strategies, therefore, the assessment of multiple contaminants, such as category, dosage, and duration, should be taken into consideration [114].

\section{Nutritional balance and combination}

Nutritional balance is a noteworthy factor for early-life nutritional intervention. Otherwise, it is likely to have the opposite effect. As evidence of this, low maternal VB12 and high folate levels have been shown to increase obesity incidence and insulin resistance in offspring [458]. In addition, DeVita and Vincent reported that the combinatorial strategies have better therapeutic effect on cancers than treatment individually [475]. The most explored epigenetics drug combinatorial strategies are DNMT inhibitors and HDAC inhibitors [476, 477]. In line with this, we have been making progress by studying the interactions between dietary epigenetic-modifying compounds and combinatorial strategies in cancer research [268, 269, 276, 283, 409, 411, 478]. Given similar epigenome dysregulation caused by environmental toxicant exposure, combination addition of epigenetics diets could be a more promising approach to resist environmental disruption. 


\section{Conclusion}

Increasing evidence has indicated that prenatal dietary intervention may partially counteract adverse outcomes caused by exposures to environmental contaminants through averting epigenome dysregulation. Diseases, exposures, and specific genes-targeted approaches are urgently required for nutritional or pharmacologic interventions, since the epigenetic processes implicated in fetal adaptation to negative environmental stimulation still lack a comprehensive understanding. Moreover, time-, sex-, and genetic background-specific; dose-dependent;and global response to parental nutrition intervention, as well as a balanced nutrition regime against multiple pollutants, should be further investigated.

\section{Abbreviations}

1,25-D3: 1,25-Dihydroxyvitamin D3; 5caC: 5-Carboxylcytosine; 5mC: 5Methylcytosine; ACSL3: Acyl-CoA synthetase long-chain family member 3; ADP: Adenosine diphosphate; AHRR: Aryl hydrocarbon receptor repressor; Alu: Arthrobacter luteus; APC: Adenomatous polyposis; BDNF: Brain-derived neurotrophic factor; BPA: Bisphenol A; CGIs: CpG islands; CNTNAP2: Cortactinassociated protein-like 2; COMT: Catechol-O-methyltransferase;

CYP1A1: Cytochrome P450 1A1; DDE: Dichloro-diphenyl-dichloroethylene; DDT: Dichloro-diphenyl-trichloroethane; DKK1: Dickkopf-related protein 1; DLGAP2: Discs large homolog-associated protein 2; DMR: Differentially methylated region; DNMT: DNA methyltransferase; DOHaD: Developmental origins of health and disease; EDCs: Endocrine-disrupting chemicals; EGCG: (-)-epigallocatechin-3-gallate; ESCs: Embryonic stem cells; FEBAD: Fetal basis of adult disease; GE: Genistein; GFI1: Growth factor independent 1; HAT: Histone acetyltransferase; HDAC: Histone deacetylase; hTERT: Human telomerase reverse transcriptase; ICM: Inner cell mass; IGF2: Insulin-like growth factor 2; ITCs: Isothiocyanates; JHDMs: JmjC-domain-containing histone demethylases; JmjC: Jumonji C; LINE-1: Long interspersed nuclear element; MBPs: Methyl-CpG-binding proteins; MetS: Metabolic syndrome; mtDNA: Mitochondrial DNA; MTHFR: Methylation of methylene tetrahydrofolate reductase; MYO1G: Myosin 1 G; NR3C1: Nuclear receptor subfamily 3 group C member 1; PAHs: Polycyclic aromatic hydrocarbons; PBDEs: Polybrominated diphenyl ethers; PBL: Peripheral blood leukocyte; PCBs: Polychlorinated biphenyls; PCG: Polycomb group; PDAC: Pancreatic ductal adenocarcinoma; PDLIM2: PDZ-LIM domain-containing protein 2. PFOA: Perfluorooctanoic acid; PGCs: Primordial germ cells; PM: Particulate matter; POPs: Persistent organic pollutants; PRDM8: PR domain containing 8; RSV: Resveratrol; RUNX3: Runt-related transcription factor; SAM: Sadenosylmethionine; Sat2: Satellite 2; Se: Selenium; SFN: Sulforaphane; SIRT1: Sirtuin 1; SULT2A1: Sulfotransferase 2A1; T2D: Type 2 diabetes; TCDD: 2,3,7,8-Tetrachlorodibenzo-p-dioxin; TET: Ten-eleven translocation; TNF-a: Tumor necrosis factor alpha; VB12: Vitamin B12; VDR: Vitamin D receptor; WA: Withaferin $\mathrm{A}$; WHO: World Health Organization

\section{Acknowledgements}

Not applicable

\section{Funding}

This work was supported in part by grants from the National Institute of Health (NCI R01CA178441, NCI R01CA204346, NCCIH K01AT009373, NIDDK P30DK056336). These funding bodies did not play any role in the design of the study and collection, analysis, and interpretation of data or in writing the manuscript.

\section{Availability of data and materials}

Not applicable

\section{Authors' contributions}

$S L$ and $M C$ wrote the first draft of this article. All authors contributed to the conception of the article and revision of the final manuscript and agree on its submission to this journal.
Ethics approval and consent to participate

Not applicable

\section{Consent for publication}

Not applicable

\section{Competing interests}

The authors declare that they have no competing interests.

\section{Publisher's Note}

Springer Nature remains neutral with regard to jurisdictional claims in published maps and institutional affiliations.

\section{Author details}

${ }^{1}$ Department of Biology, University of Alabama at Birmingham, Birmingham, AL, USA. ${ }^{2}$ Department of Pharmacology and Toxicology, University of Alabama at Birmingham, Birmingham, AL, USA. ${ }^{3}$ Comprehensive Cancer Center, University of Alabama at Birmingham, Birmingham, AL, USA. ${ }^{4}$ Nutrition Obesity Research Center, University of Alabama at Birmingham, Birmingham, AL, USA. ${ }^{5}$ Comprehensive Center for Healthy Aging, University of Alabama at Birmingham, Birmingham, AL, USA. ${ }^{6}$ Comprehensive Diabetes Center, University of Alabama at Birmingham, Birmingham, AL, USA.

Received: 7 February 2019 Accepted: 27 March 2019

Published online: 16 May 2019

\section{References}

1. Jirtle RL, Skinner MK. Environmental epigenomics and disease susceptibility. Nat Rev Genet. 2007:8(4):253.

2. Hamm CA, Costa FF. Epigenomes as therapeutic targets. Pharmacol Ther. 2015;151:72-86.

3. Waddington C. Organizers and genes cambridge. Cambridge: Cambridge University Press; 1940.

4. Jones PA, Takai D. The role of DNA methylation in mammalian epigenetics. Science. 2001;293(5532):1068-70.

5. Strahl BD, Allis CD. The language of covalent histone modifications. Nature. 2000;403(6765):41.

6. Bernstein BE, Meissner A, Lander ES. The mammalian epigenome. Cell. 2007: 128(4):669-81.

7. Law C, Barker D, Osmond C, Fall C, Simmonds S. Early growth and abdominal fatness in adult life. J Epidemiol Community Health. 1992;46(3): 184-6.

8. Hanson M, Gluckman P. Developmental origins of health and diseaseglobal public health implications. Best Pract Res Clin Obstet Gynaecol. 2015; 29(1):24-31.

9. Hanson MA, Gluckman PD. Developmental origins of health and disease: new insights. Basic Clin Pharmacol Toxicol. 2008;102(2):90-3.

10. Hardy TM, Tollefsbol TO. Epigenetic diet: impact on the epigenome and cancer. Epigenomics. 2011:3(4):503-18.

11. Dolinoy DC, Huang D, Jirtle RL. Maternal nutrient supplementation counteracts bisphenol A-induced DNA hypomethylation in early development. Proc Natl Acad Sci. 2007;104(32):13056-61.

12. Messerschmidt DM, Knowles BB, Solter D. DNA methylation dynamics during epigenetic reprogramming in the germline and preimplantation embryos. Genes Dev. 2014;28(8):812-28.

13. Ze H, Feil R, Constancia M, Fraga M, Junien C, Carel J-C, et al. Child health, developmental plasticity, and epigenetic programming. Endocr Rev. 2010; 32(2):159-224.

14. Guo F, Yan L, Guo H, Li L, Hu B, Zhao Y, et al. The transcriptome and DNA methylome landscapes of human primordial germ cells. Cell. 2015;161(6): 1437-52.

15. Vaiserman A. Epidemiologic evidence for association between adverse environmental exposures in early life and epigenetic variation: a potential link to disease susceptibility? Clin Epigenetics. 2015;7(1):96.

16. Olek A, Walter J. The pre-implantation ontogeny of the $\mathrm{H} 19$ methylation imprint. Nat Genet. 1997;17(3):275.

17. Shibata $H$, Yoda $Y$, Kato $R$, Ueda $T$, Kamiya $M$, Hiraiwa $N$, et al. A methylation imprint mark in the mouse imprinted GeneGrf1/Cdc25MmLocus shares a common feature with theU2afbp-rsGene: an association with a short tandem repeat and a hypermethylated region. Genomics. 1998;49(1):30-7. 
18. Reik W, Dean W, Walter J. Epigenetic reprogramming in mammalian development. Science. 2001;293(5532):1089-93.

19. Howell CY, Bestor TH, Ding F, Latham KE, Mertineit C, Trasler JM, et al. Genomic imprinting disrupted by a maternal effect mutation in the Dnmt1 gene. Cell. 2001;104(6):829-38.

20. Zhu P, Guo H, Ren Y, Hou Y, Dong J, Li R, et al. Single-cell DNA methylome sequencing of human preimplantation embryos. Nat Genet. 2018;50(1):12.

21. Guo H, Zhu P, Yan L, Li R, Hu B, Lian Y, et al. The DNA methylation landscape of human early embryos. Nature. 2014;511(7511):606.

22. Davis TL, Yang GJ, McCarrey JR, Bartolomei MS. The H19 methylation imprint is erased and re-established differentially on the parental alleles during male germ cell development. Hum Mol Genet. 2000;9(19):2885-94.

23. Kobayashi H, Sakurai T, Miura F, Imai M, Mochiduki K, Yanagisawa E, et al. High-resolution DNA methylome analysis of primordial germ cells identifies gender-specific reprogramming in mice. Genome Res. 2013;23(4):616-27.

24. Seisenberger S, Andrews S, Krueger F, Arand J, Walter J, Santos F, et al. The dynamics of genome-wide DNA methylation reprogramming in mouse primordial germ cells. Mol Cell. 2012;48(6):849-62.

25. Engler $P$, Haasch D, Pinkert CA, Doglio L, Glymour M, Brinster R, et al. A strain-specific modifier on mouse chromosome 4 controls the methylation of independent transgene loci. Cell. 1991;65(6):939-47.

26. Allen ND, Norris ML, Surani MA. Epigenetic control of transgene expression and imprinting by genotype-specific modifiers. Cell. 1990;61(5):853-61.

27. Duncan BK, Miller JH. Mutagenic deamination of cytosine residues in DNA. Nature. 1980;287(5782):560

28. Lessing DMC, Lee JT. X chromosome inactivation and epigenetic responses to cellular reprogramming. Annu Rev Genomics Hum Genet. 2013;14:85-110.

29. Silva SS, Rowntree RK, Mekhoubad S, Lee JT. X-chromosome inactivation and epigenetic fluidity in human embryonic stem cells. Proc Natl Acad Sci. 2008;105(12):4820-5.

30. Park J-H, Kim S-H, Lee MS, Kim M-S. Epigenetic modification by dietary factors: implications in metabolic syndrome. Mol Asp Med. 2017;54:58-70.

31. Jacobsen S, Brøns C, Bork-Jensen J, Ribel-Madsen R, Yang B, Lara E, et al. Effects of short-term high-fat overfeeding on genome-wide DNA methylation in the skeletal muscle of healthy young men. Diabetologia. 2012;55(12):3341-9.

32. Burdge GC, Lillycrop KA, Phillips ES, Slater-Jefferies JL, Jackson AA, Hanson MA. Folic acid supplementation during the juvenile-pubertal period in rats modifies the phenotype and epigenotype induced by prenatal nutrition. J Nutr. 2009;139(6):1054-60.

33. Ly A, Lee H, Chen J, Sie KK, Renlund R, Medline A, et al. Effect of maternal and postweaning folic acid supplementation on mammary tumor risk in the offspring. Cancer Res. 2011;71(3):988-97.

34. Waterland RA, Lin J-R, Smith CA, Jirtle RL. Post-weaning diet affects genomic imprinting at the insulin-like growth factor 2 (Igf2) locus. Hum Mol Genet. 2006:15(5):705-16.

35. Lillycrop K, Burdge G. Maternal diet as a modifier of offspring epigenetics. J Dev Orig Health Dis. 2015;6(2):88-95.

36. Deaton AM, Bird A. CpG islands and the regulation of transcription. Genes Dev. 2011;25(10):1010-22.

37. Bird A. DNA methylation patterns and epigenetic memory. Genes Dev. 2002;16(1):6-21

38. Fournier A, Sasai N, Nakao M, Defossez P-A. The role of methyl-binding proteins in chromatin organization and epigenome maintenance. Brief Funct Genomics. 2011;11(3):251-64.

39. Suelves $M$, Carrió E, Núñez-Álvarez Y, Peinado MA. DNA methylation dynamics in cellular commitment and differentiation. Brief Funct Genomics. 2016;15(6):443-53.

40. Li S, Zhu Y, Zhi L, Han X, Shen J, Liu Y, et al. DNA methylation variation trends during the embryonic development of chicken. PLoS One. 2016; 11(7):e0159230.

41. Yang X, Han H, De Carvalho DD, Lay FD, Jones PA, Liang G. Gene body methylation can alter gene expression and is a therapeutic target in cancer. Cancer Cell. 2014;26(4):577-90.

42. Costa Y, Ding J, Theunissen TW, Faiola F, Hore TA, Shliaha PV, et al. NANOGdependent function of TET1 and TET2 in establishment of pluripotency. Nature 2013:495(7441):370

43. Bakulski KM, Halladay A, Hu WW, Mill J, Fallin MD. Epigenetic research in neuropsychiatric disorders: the "tissue issue". Curr Behav Neurosci Rep. 2016; 3(3):264-74.
44. Novakovic B, Ryan J, Pereira N, Boughton B, Craig JM, Saffery R. Postnatal stability, tissue, and time specific effects of AHRR methylation change in response to maternal smoking in pregnancy. Epigenetics. 2014;9(3):377-86.

45. Christensen BC, Houseman EA, Marsit CJ, Zheng S, Wrensch MR, Wiemels JL, et al. Aging and environmental exposures alter tissue-specific DNA methylation dependent upon CpG island context. PLoS Genet. 2009;5(8): e1000602.

46. Hemberger M, Pedersen R. Epigenome disruptors. Science. 2010;330(6004): $598-9$.

47. Fraga MF, Esteller M. Epigenetics and aging: the targets and the marks. Trends Genet. 2007;23(8):413-8.

48. Wilson AS, Power BE, Molloy PL. DNA hypomethylation and human diseases. Biochimica et Biophysica Acta (BBA)-Reviews on Cancer. 2007. 1775(1):138-62.

49. Reichetzeder C, Putra SD, Pfab T, Slowinski T, Neuber C, Kleuser B, et al. Increased global placental DNA methylation levels are associated with gestational diabetes. Clin Epigenetics. 2016;8(1):82.

50. Jin S, Lee YK, Lim YC, Zheng Z, Lin XM, Ng DP, et al. Global DNA hypermethylation in Down syndrome placenta. PLoS Genet. 2013;9(6): e1003515.

51. Constância $M$, Hemberger $M$, Hughes J, Dean W, Ferguson-Smith $A$ Fundele R, et al. Placental-specific IGF-II is a major modulator of placental and fetal growth. Nature. 2002;417(6892):945.

52. Bourque D, Avila L, Penaherrera M, Von Dadelszen $P$, Robinson W. Decreased placental methylation at the H19/IGF2 imprinting control region is associated with normotensive intrauterine growth restriction but not preeclampsia. Placenta. 2010;31(3):197-202.

53. Gluckman PD, Lillycrop KA, Vickers MH, Pleasants AB, Phillips ES, Beedle AS, et al. Metabolic plasticity during mammalian development is directionally dependent on early nutritional status. Proc Natl Acad Sci. 2007:104(31): 12796-800.

54. Gluckman PD, Hanson MA, Beedle AS. Early life events and their consequences for later disease: a life history and evolutionary perspective. Am J Hum Biol. 2007:19(1):1-19.

55. Gluckman PD, Hanson MA. Developmental origins of disease paradigm: a mechanistic and evolutionary perspective. Pediatr Res. 2004:56(3):311.

56. Gillman MW, Barker D, Bier D, Cagampang F, Challis J, Fall C, et al. Meeting report on the 3rd International Congress on Developmental Origins of Health and Disease (DOHaD). Pediatr Res. 2007;61(5, Part 1):625.

57. Barker DJ. The developmental origins of adult disease. Eur J Epidemiol. 2003;18(8):733-6.

58. Bateson P, Barker D, Clutton-Brock T, Deb D, D'udine B, Foley RA, et al. Developmental plasticity and human health. Nature. 2004; 430(6998):419.

59. Li Y, Buckhaults P, Li S, Tollefsbol TO. Temporal efficacy of a sulforaphanebased broccoli sprout diet in prevention of breast cancer through modulation of epigenetic mechanisms. Cancer Prev Res. 2018;11(8):451-64 canprevres. 0423.2017

60. Tammen SA, Friso S, Choi S-W. Epigenetics: the link between nature and nurture. Mol Asp Med. 2013;34(4):753-64.

61. Burton GJ, Fowden AL, Thornburg KL. Placental origins of chronic disease. Physiol Rev. 2016;96(4):1509-65.

62. Feil R, Fraga MF. Epigenetics and the environment: emerging patterns and implications. Nat Rev Genet. 2012;13(2):97.

63. Ho S-M, Tang W-Y, De Frausto JB, Prins GS. Developmental exposure to estradiol and bisphenol a increases susceptibility to prostate carcinogenesis and epigenetically regulates phosphodiesterase type 4 variant 4. Cancer Res. 2006;66(11):5624-32.

64. Li S, Hursting SD, Davis BJ, MCLACHLAN JA, Barrett JC. Environmental exposure, DNA methylation, and gene regulation: lessons from diethylstilbesterol-induced cancers. Ann N Y Acad Sci. 2003;983(1):161-9.

65. Abraham E, Rousseaux S, Agier L, Giorgis-Allemand L, Tost J, Galineau J, et al. Pregnancy exposure to atmospheric pollution and meteorological conditions and placental DNA methylation. Environ Int. 2018;118:334-47.

66. Pedersen M, Stayner L, Slama R, Sørensen M, Figueras F, Nieuwenhuijsen $\mathrm{MJ}$, et al. Ambient air pollution and pregnancy-induced hypertensive disorders: a systematic review and meta-analysis. Hypertension. 2014;114: 03545 HYPERTENSIONAHA

67. Clifford A, Lang L, Chen R, Anstey KJ, Seaton A. Exposure to air pollution and cognitive functioning across the life course-a systematic literature review. Environ Res. 2016;147:383-98. 
68. Chiu Y-HM, Hsu H-HL, Coull BA, Bellinger DC, Kloog I, Schwartz J, et al. Prenatal particulate air pollution and neurodevelopment in urban children: examining sensitive windows and sex-specific associations. Environ Int. 2016:87:56-65.

69. Stieb DM, Chen L, Eshoul M, Judek S. Ambient air pollution, birth weight and preterm birth: a systematic review and meta-analysis. Environ Res. 2012; 117:100-11.

70. Valentino SA, Tarrade A, Aioun J, Mourier E, Richard C, Dahirel M, et al. Maternal exposure to diluted diesel engine exhaust alters placental function and induces intergenerational effects in rabbits. Part Fibre Toxicol. 2015; 13(1):39.

71. Wick P, Malek A, Manser P, Meili D, Maeder-Althaus X, Diener L, et al. Barrier capacity of human placenta for nanosized materials. Environ Health Perspect. 2009;118(3):432-6.

72. Zhong J, Karlsson O, Wang G, Li J, Guo Y, Lin X, et al. B vitamins attenuate the epigenetic effects of ambient fine particles in a pilot human intervention trial. Proc Natl Acad Sci. 2017;114(13):3503-8.

73. Janssen BG, Godderis L, Pieters N, Poels K, Kiciński M, Cuypers A, et al. Placental DNA hypomethylation in association with particulate air pollution in early life. Part Fibre Toxicol. 2013;10(1):22.

74. Maghbooli Z, Hossein-nezhad A, Adabi E, Asadollah-pour E, Sadeghi M, Mohammad-nabi S, et al. Air pollution during pregnancy and placental adaptation in the levels of global DNA methylation. PLoS One. 2018;13(7): e0199772.

75. Cai J, Zhao Y, Liu P, Xia B, Zhu Q, Wang X, et al. Exposure to particulate air pollution during early pregnancy is associated with placental DNA methylation. Sci Total Environ. 2017;607:1103-8.

76. Janssen BG, Munters E, Pieters N, Smeets K, Cox B, Cuypers A, et al. Placental mitochondrial DNA content and particulate air pollution during in utero life. Environ Health Perspect. 2012;120(9):1346.

77. Janssen BG, Byun H-M, Gyselaers W, Lefebvre W, Baccarelli AA, Nawrot TS. Placental mitochondrial methylation and exposure to airborne particulate matter in the early life environment: an ENVIR ON AGE birth cohort study. Epigenetics. 2015;10(6):536-44.

78. Saenen ND, Vrijens K, Janssen BG, Roels HA, Neven KY, Vanden Berghe W, et al. Lower placental leptin promoter methylation in association with fine particulate matter air pollution during pregnancy and placental nitrosative stress at birth in the ENVIR ON AGE cohort. Environ Health Perspect. 2016;125(2):262-8.

79. Alvarado-Cruz I, Sánchez-Guerra M, Hernández-Cadena L, De Vizcaya-Ruiz A, Mugica V, Pelallo-Martínez NA, et al. Increased methylation of repetitive elements and DNA repair genes is associated with higher DNA oxidation in children in an urbanized, industrial environment. Mutat Res/Genetic Toxicology and Environmental Mutagenesis. 2017;813:27-36.

80. Tsamou M, Vrijens K, Madhloum N, Lefebvre W, Vanpoucke C, Nawrot TS. Air pollution-induced placental epigenetic alterations in early life: a candidate miRNA approach. Epigenetics. 2018;13(2):135-46

81. Alshaarawy O, Anthony JC. Month-wise estimates of tobacco smoking during pregnancy for the United States, 2002-2009. Matern Child Health J. 2015;19(5):1010-5.

82. Suter M, Ma J, Harris AS, Patterson L, Brown KA, Shope C, et al. Maternal tobacco use modestly alters correlated epigenome-wide placental DNA methylation and gene expression. Epigenetics. 2011;6(11): 1284-94.

83. Wilhelm-Benartzi CS, Houseman EA, Maccani MA, Poage GM, Koestler DC, Langevin SM, et al. In utero exposures, infant growth, and DNA methylation of repetitive elements and developmentally related genes in human placenta. Environ Health Perspect. 2011;120(2):296-302.

84. Rotroff DM, Joubert BR, Marvel SW, Håberg SE, Wu MC, Nilsen RM, et al. Maternal smoking impacts key biological pathways in newborns through epigenetic modification in utero. BMC Genomics. 2016;17(1):976.

85. Joubert BR, Felix JF, Yousefi P, Bakulski KM, Just AC, Breton C, et al. DNA methylation in newborns and maternal smoking in pregnancy: genomewide consortium meta-analysis. Am J Hum Genet. 2016;98(4):680-96.

86. Ladd-Acosta C, Shu C, Lee BK, Gidaya N, Singer A, Schieve LA, et al. Presence of an epigenetic signature of prenatal cigarette smoke exposure in childhood. Environ Res. 2016;144:139-48.

87. Breton CV, Siegmund KD, Joubert BR, Wang X, Qui W, Carey V, et al. Prenatal tobacco smoke exposure is associated with childhood DNA CpG methylation. PLoS One. 2014;9(6):e99716.

88. Lee KW, Richmond R, Hu P, French L, Shin J, Bourdon C, et al. Prenatal exposure to maternal cigarette smoking and DNA methylation: epigenome- wide association in a discovery sample of adolescents and replication in an independent cohort at birth through 17 years of age. Environ Health Perspect. 2014;123(2):193-9.

89. Windham GC, Hopkins B, Fenster L, Swan SH. Prenatal active or passive tobacco smoke exposure and the risk of preterm delivery or low birth weight. Epidemiology. 2000;11:427-33.

90. Cox B, Martens E, Nemery B, Vangronsveld J, Nawrot TS. Impact of a stepwise introduction of smoke-free legislation on the rate of preterm births: analysis of routinely collected birth data. BMJ. 2013;346:f441.

91. Fantuzzi G, Aggazzotti G, Righi E, Facchinetti F, Bertucci E, Kanitz S, et al. Preterm delivery and exposure to active and passive smoking during pregnancy: a case-control study from Italy. Paediatr Perinat Epidemiol. 2007; 21(3):194-200

92. Somm E, Schwitzgebel VM, Vauthay DM, Aubert ML, Hüppi PS. Prenatal nicotine exposure and the programming of metabolic and cardiovascular disorders. Mol Cell Endocrinol. 2009;304(1-2):69-77.

93. Maritz GS, Harding R. Life-long programming implications of exposure to tobacco smoking and nicotine before and soon after birth: evidence for altered lung development. Int J Environ Res Public Health. 2011;8(3): 875-98.

94. Doherty S, Grabowski J, Hoffman C, Ng S, Zelikoff J. Early life insult from cigarette smoke may be predictive of chronic diseases later in life. Biomarkers. 2009;14(sup 1):97-101.

95. Guerrero-Preston R, Goldman LR, Brebi-Mieville P, Ili-Gangas C, LeBron C, Witter FR, et al. Global DNA hypomethylation is associated with in utero exposure to cotinine and perfluorinated alkyl compounds. Epigenetics. 2010;5(6):539-46.

96. Flom JD, Ferris JS, Liao Y, Tehranifar P, Richards CB, Cho YH, et al. Prenatal smoke exposure and genomic DNA methylation in a multiethnic birth cohort. Cancer Epidemiol Biomarkers Prev. 2011;20(12):2518-23.

97. Janssen BG, Gyselaers W, Byun H-M, Roels HA, Cuypers A, Baccarelli AA, et al. Placental mitochondrial DNA and CYP1A1 gene methylation as molecular signatures for tobacco smoke exposure in pregnant women and the relevance for birth weight. J Transl Med. 2017;15(1):5.

98. Breton CV, Byun H-M, Wenten M, Pan F, Yang A, Gilliland FD. Prenatal tobacco smoke exposure affects global and gene-specific DNA methylation. Am J Respir Crit Care Med. 2009;180(5):462-7.

99. Ivorra C, Fraga MF, Bayón GF, Fernández AF, Garcia-Vicent C, Chaves FJ, et al. DNA methylation patterns in newborns exposed to tobacco in utero. J Transl Med. 2015;13(1):25.

100. Richmond RC, Simpkin AJ, Woodward G, Gaunt TR, Lyttleton O, McArdle $W L$, et al. Prenatal exposure to maternal smoking and offspring DNA methylation across the lifecourse: findings from the Avon Longitudinal Study of Parents and Children (ALSPAC). Hum Mol Genet. 2014;24(8):2201-17.

101. Markunas CA, Xu Z, Harlid S, Wade PA, Lie RT, Taylor JA, et al. Identification of DNA methylation changes in newborns related to maternal smoking during pregnancy. Environ Health Perspect. 2014;122(10):1147.

102. Maccani JZ, Koestler DC, Houseman EA, Marsit CJ, Kelsey KT. Placental DNA methylation alterations associated with maternal tobacco smoking at the RUNX3 gene are also associated with gestational age. Epigenomics. 2013; 5(6):619-30.

103. Suter M, Abramovici A, Showalter L, Hu M, Do Shope C, Varner M, et al. In utero tobacco exposure epigenetically modifies placental CYP1A1 expression. Metabolism-Clinical and Experimental. 2010;59(10):1481-90.

104. Joubert BR, Håberg SE, Nilsen RM, Wang X, Vollset SE, Murphy SK, et al. 450K epigenome-wide scan identifies differential DNA methylation in newborns related to maternal smoking during pregnancy. Environ Health Perspect. 2012;120(10):1425.

105. Murphy SK, Adigun A, Huang Z, Overcash F, Wang F, Jirtle RL, et al. Genderspecific methylation differences in relation to prenatal exposure to cigarette smoke. Gene. 2012;494(1):36-43.

106. Wang IJ, Chen SL, Lu TP, Chuang E, Chen PC. Prenatal smoke exposure, DNA methylation, and childhood atopic dermatitis. Clin Exp Allergy. 2013; 43(5):535-43.

107. Rzehak P, Saffery R, Reischl E, Covic M, Wahl S, Grote V, et al. Maternal smoking during pregnancy and DNA-methylation in children at age 5.5 years: epigenome-wide-analysis in the European Childhood Obesity Project (CHOP)-study. PLoS One. 2016;11(5):e0155554.

108. Toledo-Rodriguez M, Lotfipour S, Leonard G, Perron M, Richer L, Veillette S, et al. Maternal smoking during pregnancy is associated with epigenetic 
modifications of the brain-derived neurotrophic factor- 6 exon in adolescent offspring. Am J Med Genet B Neuropsychiatr Genet. 2010;153(7):1350-4.

109. Maccani MA, Avissar-Whiting M, Banister CE, McGonnigal B, Padbury JF, Marsit CJ. Maternal cigarette smoking during pregnancy is associated with downregulation of miR-16, miR-21, and miR-146a in the placenta. Epigenetics. 2010;5(7):583-9.

110. Zhang B, Hong $X$, Ji H, Tang WY, Kimmel M, Ji Y, et al. Maternal smoking during pregnancy and cord blood DNA methylation: new insight on sex differences and effect modification by maternal folate levels. Epigenetics. 2018;13(5):505-18.

111. Bouwland-Both Ml, van Mil NH, Tolhoek CP, Stolk L, Eilers PH, Verbiest MM, et al. Prenatal parental tobacco smoking, gene specific DNA methylation, and newborns size: the Generation R study. Clin Epigenetics. 2015;7(1):83.

112. Haritash A, Kaushik C. Biodegradation aspects of polycyclic aromatic hydrocarbons (PAHs): a review. J Hazard Mater. 2009;169(1-3):1-15.

113. Boström C-E, Gerde P, Hanberg A, Jernström B, Johansson C, Kyrklund T, et al. Cancer risk assessment, indicators, and guidelines for polycyclic aromatic hydrocarbons in the ambient air. Environ Health Perspect. 2002; 110(Suppl 3):451.

114. Martin EM, Fry RC. Environmental influences on the epigenome: exposureassociated DNA methylation in human populations. Annu Rev Public Health. 2018;39:309-33.

115. Perera FP, Rauh V, Whyatt RM, Tsai W-Y, Tang D, Diaz D, et al. Effect of prenatal exposure to airborne polycyclic aromatic hydrocarbons on neurodevelopment in the first 3 years of life among inner-city children. Environ Health Perspect. 2006;114(8):1287.

116. Choi H, Jedrychowski W, Spengler J, Camann DE, Whyatt RM, Rauh V, et al. International studies of prenatal exposure to polycyclic aromatic hydrocarbons and fetal growth. Environ Health Perspect. 2006;114(11):1744.

117. Perera FP, Rauh V, Tsai W-Y, Kinney P, Camann D, Barr D, et al. Effects of transplacental exposure to environmental pollutants on birth outcomes in a multiethnic population. Environ Health Perspect. 2003;111(2):201.

118. Herbstman JB, Tang D, Zhu D, Qu L, Sjödin A, Li Z, et al. Prenatal exposure to polycyclic aromatic hydrocarbons, benzo [a] pyrene-DNA adducts, and genomic DNA methylation in cord blood. Environ Health Perspect. 2012;120(5):733.

119. Lee J, Kalia V, Perera F, Herbstman J, Li T, Nie J, et al. Prenatal airborne polycyclic aromatic hydrocarbon exposure, LINE1 methylation and child development in a Chinese cohort. Environ Int. 2017;99:315-20.

120. Perera F, Tang WY, Herbstman J, Tang D, Levin L, Miller R, et al. Relation of DNA methylation of $5^{\prime}-\mathrm{CpG}$ island of ACSL3 to transplacental exposure to airborne polycyclic aromatic hydrocarbons and childhood asthma. PLoS One. 2009:4(2):e4488.

121. Kingsley SL, Eliot MN, Whitsel EA, Huang Y-T, Kelsey KT, Marsit CJ, et al. Maternal residential proximity to major roadways, birth weight, and placental DNA methylation. Environ Int. 2016:92:43-9.

122. Gruzieva O, Xu C-J, Breton CV, Annesi-Maesano I, Antó JM, Auffray C, et al. Epigenome-wide meta-analysis of methylation in children related to prenatal NO2 air pollution exposure. Environ Health Perspect. 2016;125(1): 104-10.

123. Clifford RL, Jones MJ, Maclsaac JL, McEwen LM, Goodman SJ, Mostafavi S, et al. Inhalation of diesel exhaust and allergen alters human bronchial epithelium DNA methylation. J Allergy Clin Immunol. 2017;139(1):112-21.

124. Guerrero-Bosagna C, Covert TR, Haque MM, Settles M, Nilsson EE, Anway $M D$, et al. Epigenetic transgenerational inheritance of vinclozolin induced mouse adult onset disease and associated sperm epigenome biomarkers. Reprod Toxicol. 2012;34(4):694-707.

125. Fudvoye J, Bourguignon J-P, Parent A-S. Endocrine-disrupting chemicals and human growth and maturation: a focus on early critical windows of exposure In: Vitam Horm, vol. 94. Cambridge: Academic Press; 2014. p. 1-25.

126. Annamalai J, Namasivayam $\mathrm{V}$. Endocrine disrupting chemicals in the atmosphere: their effects on humans and wildlife. Environ Int. 2015;76:78-97.

127. Vaiserman A. Early-life exposure to endocrine disrupting chemicals and later-life health outcomes: an epigenetic bridge? Aging Dis. 2014;5(6):419.

128. Kundakovic $M$, Champagne FA. Epigenetic perspective on the developmental effects of bisphenol A. Brain Behav Immun. 2011;25(6): 1084-93.

129. Bernal AJ, Jirtle RL. Epigenomic disruption: the effects of early developmental exposures. Birth Defects Res Part A: Clin Mol Teratol. 2010; 88(10):938-44.

130. Markey CM, Coombs MA, Sonnenschein C, Soto AM. Mammalian development in a changing environment: exposure to endocrine disruptors reveals the developmental plasticity of steroid-hormone target organs. Evol Dev. 2003;5(1):67-75.

131. Anway MD, Cupp AS, Uzumcu M, Skinner MK. Epigenetic transgenerational actions of endocrine disruptors and male fertility. Science. 2005;308(5727): 1466-9.

132. Yaoi T, Itoh K, Nakamura K, Ogi H, Fujiwara Y, Fushiki S. Genome-wide analysis of epigenomic alterations in fetal mouse forebrain after exposure to low doses of bisphenol A. Biochem Biophys Res Commun. 2008;376(3):563-7.

133. Tang W-Y, Newbold R, Mardilovich K, Jefferson W, Cheng RY, Medvedovic $\mathrm{M}$, et al. Persistent hypomethylation in the promoter of nucleosomal binding protein 1 (Nsbp 1) correlates with overexpression of Nsbp 1 in mouse uteri neonatally exposed to diethylstilbestrol or genistein. Endocrinology. 2008;149(12):5922-31.

134. Corrales J, Kristofco LA, Steele WB, Yates BS, Breed CS, Williams ES, et al. Global assessment of bisphenol $A$ in the environment: review and analysis of its occurrence and bioaccumulation. Dose-Response. 2015;13(3): 1559325815598308.

135. Calafat AM, Kuklenyik Z, Reidy JA, Caudill SP, Ekong J, Needham LL. Urinary concentrations of bisphenol $\mathrm{A}$ and 4-nonylphenol in a human reference population. Environ Health Perspect. 2004;113(4):391-5.

136. Takahashi O, Oishi S. Disposition of orally administered 2, 2-Bis (4hydroxyphenyl) propane (bisphenol A) in pregnant rats and the placental transfer to fetuses. Environ Health Perspect. 2000;108(10):931.

137. Konieczna A, Rutkowska A, Rachon D. Health risk of exposure to Bisphenol A (BPA). Rocz Państw Zakł Hig. 2015;66(1):5-11.

138. Doherty LF, Bromer JG, Zhou Y, Aldad TS, Taylor HS. In utero exposure to diethylstilbestrol (DES) or bisphenol-a (BPA) increases EZH2 expression in the mammary gland: an epigenetic mechanism linking endocrine disruptors to breast cancer. Horm Cancer. 2010;1(3):146-55.

139. Bromer JG, Zhou Y, Taylor MB, Doherty L, Taylor HS. Bisphenol-a exposure in utero leads to epigenetic alterations in the developmental programming of uterine estrogen response. FASEB J. 2010;24(7):2273-80.

140. Ma Y, Xia W, Wang D, Wan Y, Xu B, Chen X, et al. Hepatic DNA methylation modifications in early development of rats resulting from perinatal BPA exposure contribute to insulin resistance in adulthood. Diabetologia. 2013;56(9):2059-67.

141. Faulk C, Kim JH, Anderson OS, Nahar MS, Jones TR, Sartor MA, et al. Detection of differential DNA methylation in repetitive DNA of mice and humans perinatally exposed to bisphenol a. Epigenetics. 2016;11(7):489-500.

142. Veiga-Lopez A, Luense L, Christenson LK, Padmanabhan V. Developmental programming: gestational bisphenol-a treatment alters trajectory of fetal ovarian gene expression. Endocrinology. 2013;154(5):1873-84.

143. Nahar MS, Liao C, Kannan K, Harris C, Dolinoy DC. In utero bisphenol A concentration, metabolism, and global DNA methylation across matched placenta, kidney, and liver in the human fetus. Chemosphere. 2015:124:54-60.

144. Faulk C, Kim JH, Jones TR, McEachin RC, Nahar MS, Dolinoy DC, et al. Bisphenol A-associated alterations in genome-wide DNA methylation and gene expression patterns reveal sequence-dependent and non-monotonic effects in human fetal liver. Environ Epigenet. 2015;1(1):dvv006.

145. Nahar MS, Kim JH, Sartor MA, Dolinoy DC. Bisphenol A-associated alterations in the expression and epigenetic regulation of genes encoding xenobiotic metabolizing enzymes in human fetal liver. Environ Mol Mutagen. 2014:55(3):184-95.

146. Salian S, Doshi T, Vanage G. Perinatal exposure of rats to bisphenol A affects the fertility of male offspring. Life Sci. 2009;85(21-22):742-52.

147. Salian S, Doshi T, Vanage G. Impairment in protein expression profile of testicular steroid receptor coregulators in male rat offspring perinatally exposed to bisphenol A. Life Sci. 2009;85(1-2):11-8.

148. Manikkam M, Guerrero-Bosagna C, Tracey R, Haque MM, Skinner MK. Transgenerational actions of environmental compounds on reproductive disease and identification of epigenetic biomarkers of ancestral exposures. PLoS One. 2012;7(2):e31901.

149. Kelce WR, Monosson E, Gamcsik MP, Laws SC, Gray LE. Environmental hormone disruptors: evidence that vinclozolin developmental toxicity is mediated by antiandrogenic metabolites. Toxicol Appl Pharmacol. 1994; 126(2):276-85

150. Anway MD, Leathers C, Skinner MK. Endocrine disruptor vinclozolin induced epigenetic transgenerational adult-onset disease. Endocrinology. 2006; 147(12):5515-23.

151. Stouder C, Paoloni-Giacobino A. Transgenerational effects of the endocrine disruptor vinclozolin on the methylation pattern of imprinted genes in the mouse sperm. Reproduction. 2010;139(2):373-9. 
152. Guerrero-Bosagna C, Settles M, Lucker B, Skinner MK. Epigenetic transgenerational actions of vinclozolin on promoter regions of the sperm epigenome. PLoS One. 2010;5(9):e13100.

153. Anway MD, Memon MA, Uzumcu M, Skinner MK. Transgenerational effect of the endocrine disruptor vinclozolin on male spermatogenesis. J Androl. 2006;27(6):868-79.

154. Uzumcu M, Suzuki H, Skinner MK. Effect of the anti-androgenic endocrine disruptor vinclozolin on embryonic testis cord formation and postnatal testis development and function. Reprod Toxicol. 2004;18(6):765-74.

155. Wolf CJ, LeBlanc GA, Ostby JS, Gray LE Jr. Characterization of the period of sensitivity of fetal male sexual development to vinclozolin. Toxicol Sci. 2000; 55(1):152-61.

156. Chang H-S, Anway MD, Rekow SS, Skinner MK. Transgenerational epigenetic imprinting of the male germline by endocrine disruptor exposure during gonadal sex determination. Endocrinology. 2006:147(12):5524-41.

157. Organization WH. Persistent organic pollutants: impact on child health. 2010.

158. Herbstman JB, Sjödin A, Kurzon M, Lederman SA, Jones RS, Rauh V, et al. Prenatal exposure to PBDEs and neurodevelopment. Environ Health Perspect. 2010;118(5):712

159. Rogan WJ, Ragan NB. Evidence of effects of environmental chemicals on the endocrine system in children. Pediatrics. 2003;112(Supplement 1):247-52

160. Jacobson JL, Jacobson SW, Schwartz PM, Fein GG, Dowler JK. Prenatal exposure to environmental toxin: a test of the multiple effects model. Dev Psychol. 1984;20(4):523

161. Collins WT Jr, Capen CC. Fine structural lesions and hormonal alterations in thyroid glands of perinatal rats exposed in utero and by the milk to polychlorinated biphenyls. Am J Pathol. 1980;99(1):125.

162. Darvill T, Lonky E, Reihman J, Stewart P, Pagano J. Prenatal exposure to PCBs and infant performance on the Fagan test of infant intelligence. Neurotoxicology. 2000;21(6):1029-38.

163. Eskenazi B, Marks AR, Bradman A, Fenster L, Johnson C, Barr DB, et al. In utero exposure to dichlorodiphenyltrichloroethane (DDT) and dichlorodiphenyldichloroethylene (DDE) and neurodevelopment among young Mexican American children. Pediatrics. 2006;118(1):233-41.

164. Mocarelli P, Gerthoux PM, Ferrari E, Patterson DG Jr, Kieszak SM, Brambilla P, et al. Paternal concentrations of dioxin and sex ratio of offspring. Lancet. 2000;355(9218):1858-63.

165. Guo YL, Hsu P-C, Hsu C-C, Lambert GH. Semen quality after prenatal exposure to polychlorinated biphenyls and dibenzofurans. Lancet. 2000; 356(9237):1240-1.

166. Newbold RR, Padilla-Banks E, Jefferson WN, Heindel JJ. Effects of endocrine disruptors on obesity. Int J Androl. 2008;31(2):201-8.

167. Dewailly E, Ayotte P, Bruneau S, Gingras S, Belles-Isles M, Roy R. Susceptibility to infections and immune status in Inuit infants exposed to organochlorines. Environ Health Perspect. 2000;108(3):205.

168. Huen K, Yousefi P, Bradman A, Yan L, Harley KG, Kogut K, et al. Effects of age, sex, and persistent organic pollutants on DNA methylation in children. Environ Mol Mutagen. 2014;55(3):209-22.

169. Dao T, Hong X, Wang $X$, Tang W-Y. Aberrant 5'-CpG methylation of cord blood TNFa associated with maternal exposure to polybrominated diphenyl ethers. PLoS One. 2015;10(9):e0138815.

170. Kappil MA, Li Q, Li A, Dassanayake PS, Xia Y, Nanes JA, et al. In utero exposures to environmental organic pollutants disrupt epigenetic marks linked to fetoplacental development. Environ Epigenet. 2016;2(1):dvv013.

171. Zhao Y, Liu P, Wang J, Xiao X, Meng X, Zhang Y. Umbilical cord blood PBDEs concentrations are associated with placental DNA methylation. Environ Int. 2016:97:1-6.

172. Kobayashi S, Azumi K, Goudarzi H, Araki A, Miyashita C, Kobayashi S, et al. Effects of prenatal perfluoroalkyl acid exposure on cord blood IGF2/H19 methylation and ponderal index: the Hokkaido study. J Expo Sci Environ Epidemiol. 2017:27(3):251

173. Leter G, Consales C, Eleuteri P, Uccelli R, Specht IO, Toft G, et al. Exposure to perfluoroalkyl substances and sperm DNA global methylation in Arctic and European populations. Environ Mol Mutagen. 2014;55(7):591-600.

174. Consales C, Toft G, Leter G, Bonde JPE, Uccelli R, Pacchierotti F, et al. Exposure to persistent organic pollutants and sperm DNA methylation changes in Arctic and European populations. Environ Mol Mutagen. 2016; 57(3):200-9.

175. Somm E, Stouder C, Paoloni-Giacobino A. Effect of developmental dioxin exposure on methylation and expression of specific imprinted genes in mice. Reprod Toxicol. 2013;35:150-5.
176. Wu Q, Ohsako S, Ishimura R, Suzuki JS, Tohyama C. Exposure of mouse preimplantation embryos to 2, 3, 7, 8-tetrachlorodibenzo-p-dioxin (TCDD) alters the methylation status of imprinted genes $\mathrm{H} 19$ and lgf2. Biol Reprod. 2004:70(6):1790-7.

177. Bromer JG, Wu J, Zhou Y, Taylor HS. Hypermethylation of homeobox A10 by in utero diethylstilbestrol exposure: an epigenetic mechanism for altered developmental programming. Endocrinology. 2009;150(7):3376-82.

178. Li S, Hansman R, Newbold R, Davis B, McLachlan JA, Barrett JC. Neonatal diethylstilbestrol exposure induces persistent elevation of c-fos expression and hypomethylation in its exon-4 in mouse uterus. Mol Carcinog: Published in cooperation with the University of Texas MD Anderson Cancer Center. 2003;38(2):78-84

179. Zama AM, Uzumcu M. Fetal and neonatal exposure to the endocrine disruptor methoxychlor causes epigenetic alterations in adult ovarian genes. Endocrinology. 2009;150(10):4681-91.

180. Bruner-Tran KL, Osteen KG. Developmental exposure to TCDD reduces fertility and negatively affects pregnancy outcomes across multiple generations. Reprod Toxicol. 2011;31(3):344-50.

181. Järup L. Hazards of heavy metal contamination. Br Med Bull. 2003;68(1):167-82.

182. He J, Charlet L. A review of arsenic presence in China drinking water. Jydrol. 2013;492:79-88.

183. Gustin K, Tofail F, Vahter M, Kippler M. Cadmium exposure and cognitive abilities and behavior at 10 years of age: a prospective cohort study. Environ Int. 2018;113:259-68.

184. Quazi S, Sarkar D, Datta R. Human health risk from arsenical pesticide contaminated soils: a long-term greenhouse study. J Hazard Mater. 2013;262: 1031-8.

185. Aoki Y, Yee J, Mortensen ME. Blood cadmium by race/hispanic origin: the role of smoking. Environ Res. 2017;155:193-8.

186. O'Connor D, Hou D, Ye J, Zhang Y, Ok YS, Song Y, et al. Lead-based paint remains a major public health concern: a critical review of global production, trade, use, exposure, health risk, and implications. Environ Int. 2018;121:85-101.

187. Safruk AM, McGregor E, Aslund MLW, Cheung PH, Pinsent C, Jackson BJ, et al. The influence of lead content in drinking water, household dust, soil, and paint on blood lead levels of children in Flin Flon, Manitoba and Creighton, Saskatchewan. Sci Total Environ. 2017;593:202-10.

188. Azad AM, Frantzen S, Bank MS, Johnsen IA, Tessier E, Amouroux D, et al. Spatial distribution of mercury in seawater, sediment, and seafood from the Hardangerfjord ecosystem, Norway. Sci Total Environ. 2019;667:622-37.

189. Milton AH, Hore SK, Hossain MZ, Rahman M. Bangladesh arsenic mitigation programs: lessons from the past. Emerg Health Threats J. 2012;5(1):7269.

190. Cardenas A, Koestler DC, Houseman EA, Jackson BP, Kile ML, Karagas MR, et al. Differential DNA methylation in umbilical cord blood of infants exposed to mercury and arsenic in utero. Epigenetics. 2015;10(6):508-15.

191. Green BB, Karagas MR, Punshon T, Jackson BP, Robbins DJ, Houseman EA, et al. Epigenome-wide assessment of DNA methylation in the placenta and arsenic exposure in the New Hampshire Birth Cohort Study (USA). Environ Health Perspect. 2016:124(8):1253.

192. Kile ML, Houseman EA, Baccarelli AA, Quamruzzaman Q, Rahman M, Mostofa $G$, et al. Effect of prenatal arsenic exposure on DNA methylation and leukocyte subpopulations in cord blood. Epigenetics. 2014:9(5):774-82.

193. Pilsner JR, Hall MN, Liu X, llievski V, Slavkovich V, Levy D, et al. Influence of prenatal arsenic exposure and newborn sex on global methylation of cord blood DNA. PLoS One. 2012;7(5):e37147.

194. Broberg K, Ahmed S, Engström K, Hossain MB, Mlakar SJ, Bottai M, et al. Arsenic exposure in early pregnancy alters genome-wide DNA methylation in cord blood, particularly in boys. J Dev Orig Health Dis. 2014;5(4):288-98.

195. Fry RC, Navasumrit P, Valiathan C, Svensson JP, Hogan BJ, Luo M, et al. Activation of inflammation/NF-KB signaling in infants born to arsenicexposed mothers. PLoS Genet. 2007;3(11):e207.

196. Koestler DC, Avissar-Whiting M, Houseman EA, Karagas MR, Marsit CJ. Differential DNA methylation in umbilical cord blood of infants exposed to low levels of arsenic in utero. Environ Health Perspect. 2013;121(8):971.

197. Rojas D, Rager JE, Smeester L, Bailey KA, Drobná Z, Rubio-Andrade M, et al. Prenatal arsenic exposure and the epigenome: identifying sites of 5-methylcytosine alterations that predict functional changes in gene expression in newborn cord blood and subsequent birth outcomes. Toxicol Sci. 2014;143(1):97-106.

198. Niedzwiecki MM, Liu X, Hall MN, Thomas T, Slavkovich V, llievski V, et al. Sex-specific associations of arsenic exposure with global DNA 
methylation and hydroxymethylation in leukocytes: results from two studies in Bangladesh. Cancer Epidemiol Biomarkers Prev. 2015;24(11):1748-57.

199. Cardenas A, Houseman EA, Baccarelli AA, Quamruzzaman Q, Rahman M, Mostofa G, et al. In utero arsenic exposure and epigenome-wide associations in placenta, umbilical artery, and human umbilical vein endothelial cells. Epigenetics. 2015;10(11):1054-63.

200. Intarasunanont $P$, Navasumrit $P$, Waraprasit $S$, Chaisatra K, Suk WA, Mahidol $C$, et al. Effects of arsenic exposure on DNA methylation in cord blood samples from newborn babies and in a human lymphoblast cell line. Environ Health. 2012;11(1):31.

201. Kile ML, Baccarelli A, Hoffman E, Tarantini L, Quamruzzaman Q, Rahman $M$, et al. Prenatal arsenic exposure and DNA methylation in maternal and umbilical cord blood leukocytes. Environ Health Perspect. 2012; 120(7):1061

202. Schoeters G, HOND ED, Zuurbier M, Naginiene R, Van den Hazel P, Stilianakis N, et al. Cadmium and children: exposure and health effects. Acta Paediatr. 2006;95:50-4.

203. Vidal AC, Semenova V, Darrah T, Vengosh A, Huang Z, King K, et al. Maternal cadmium, iron and zinc levels, DNA methylation and birth weight. BMC Pharmacol Toxicol. 2015;16(1):20.

204. Kippler M, Engström K, Mlakar SJ, Bottai M, Ahmed S, Hossain MB, et al. Sexspecific effects of early life cadmium exposure on DNA methylation and implications for birth weight. Epigenetics. 2013;8(5):494-503.

205. Sanders A, Smeester L, Rojas D, DeBussycher T, Wu M, Wright F, et al. Cadmium exposure and the epigenome: exposure-associated patterns of DNA methylation in leukocytes from mother-baby pairs. Epigenetics. 2014; $9(2): 212-21$

206. Everson TM, Armstrong DA, Jackson BP, Green BB, Karagas MR, Marsit CJ. Maternal cadmium, placental PCDHAC1, and fetal development. Reprod Toxicol. 2016;65:263-71.

207. Hossain MB, Vahter M, Concha G, Broberg K. Low-level environmental cadmium exposure is associated with DNA hypomethylation in Argentinean women. Environ Health Perspect. 2012;120(6):879.

208. Everson TM, Punshon T, Jackson BP, Hao K, Lambertini L, Chen J, et al. Cadmium-associated differential methylation throughout the placental genome: epigenome-wide association study of two US birth cohorts. Environ Health Perspect. 2018;126(1):017010.

209. Xu L-H, Mu F-F, Zhao J-H, He Q, Cao C-L, Yang H, et al. Lead induces apoptosis and histone hyperacetylation in rat cardiovascular tissues. PLoS One. 2015;10(6):e0129091.

210. Maret $W$. The bioinorganic chemistry of lead in the context of its toxicity. In: Lead-its effects on environment and health, vol. 17; 2017. p. 1-20.

211. Brucker N, Moro A, Charão M, Bubols G, Nascimento S, Goethel G, et al. Relationship between blood metals and inflammation in taxi drivers. Clin Chim Acta. 2015:444:176-81.

212. Yakub M, lqbal MP. Association of blood lead (Pb) and plasma homocysteine: a cross sectional survey in Karachi, Pakistan. PLoS One. 2010; 5(7):e11706

213. Eid A, Bihaqi SW, Renehan WE, Zawia NH. Developmental lead exposure and lifespan alterations in epigenetic regulators and their correspondence to biomarkers of Alzheimer's disease. Alzheimer's Dementia: Diagnosis, Assessment \& Disease Monitoring. 2016;2:123-31.

214. Lin N, Qin S, Luo S, Cui S, Huang G, Zhang X. Homocysteine induces cytotoxicity and proliferation inhibition in neural stem cells via DNA methylation in vitro. FEBS J. 2014;281(8):2088-96.

215. Perng W, Villamor E, Shroff M, Nettleton J, Pilsner J, Liu Y, et al. Dietary intake, plasma homocysteine, and repetitive element DNA methylation in the multi-ethnic study of atherosclerosis (MESA). Nutr Metab Cardiovasc Dis. 2014;24(6):614-22.

216. Yang X, Tian J, Liang Y, Ma C, Yang A, Wang J, et al. Homocysteine induces blood vessel global hypomethylation mediated by LOX-1. Genet Mol Res. 2014;13(2):3787-99.

217. Xu L, Chen J, Gao J, Yu H, Yang P. Crosstalk of homocysteinylation, methylation and acetylation on histone H3. Analyst. 2015;140(9):3057-63.

218. Bolin CM, Basha R, Cox D, Zawia NH, Maloney B, Lahiri DK, et al. Exposure to lead and the developmental origin of oxidative DNA damage in the aging brain. FASEB J. 2006;20(6):788-90.

219. Zawia NH, Lahiri DK, Cardozo-Pelaez F. Epigenetics, oxidative stress, and Alzheimer disease. Free Radic Biol Med. 2009;46(9):1241-9.

220. Maloney B, Lahiri DK. Epigenetics of dementia: understanding the disease as a transformation rather than a state. Lancet Neurol. 2016;15(7):760-74.
221. Wu J, Basha MR, Brock B, Cox DP, Cardozo-Pelaez F, McPherson CA, et al. Alzheimer's disease (AD)-like pathology in aged monkeys after infantile exposure to environmental metal lead $(\mathrm{Pb})$ : evidence for a developmental origin and environmental link for AD. J Neurosci. 2008;28(1):3-9.

222. Goodrich JM, Sánchez BN, Dolinoy DC, Zhang Z, Hernández-Ávila M, Hu H, et al. Quality control and statistical modeling for environmental epigenetics: a study on in utero lead exposure and DNA methylation at birth. Epigenetics. 2015;10(1):19-30.

223. Nye MD, King KE, Darrah TH, Maguire R, Jima DD, Huang Z, et al. Maternal blood lead concentrations, DNA methylation of MEG3 DMR regulating the DLK1/MEG3 imprinted domain and early growth in a multiethnic cohort. Environ Epigenet. 2016;2(1):dvv009.

224. Pilsner JR, Hu H, Ettinger A, Sánchez BN, Wright RO, Cantonwine D, et al. Influence of prenatal lead exposure on genomic methylation of cord blood DNA. Environ Health Perspect. 2009;117(9):1466

225. Masoud AM, Bihaqi SW, Machan JT, Zawia NH, Renehan WE. Early-life exposure to lead $(\mathrm{Pb})$ alters the expression of microRNA that target proteins associated with Alzheimer's disease. J Alzheimers Dis. 2016;51(4):1257-64.

226. Sen A, Heredia N, Senut M-C, Land S, Hollocher K, Lu X, et al. Multigenerational epigenetic inheritance in humans: DNA methylation changes associated with maternal exposure to lead can be transmitted to the grandchildren. Sci Rep. 2015;5:14466.

227. Sen A, Cingolani P, Senut M-C, Land S, Mercado-Garcia A, Tellez-Rojo MM, et al. Lead exposure induces changes in 5-hydroxymethylcytosine clusters in CpG islands in human embryonic stem cells and umbilical cord blood. Epigenetics. 2015;10(7):607-21.

228. Sen A, Heredia N, Senut M-C, Hess M, Land S, Qu W, et al. Early life lead exposure causes gender-specific changes in the DNA methylation profile of DNA extracted from dried blood spots. Epigenomics. 2015;7(3):379-93.

229. Maccani JZ, Koestler DC, Houseman EA, Armstrong DA, Marsit CJ, Kelsey KT. DNA methylation changes in the placenta are associated with fetal manganese exposure. Reprod Toxicol. 2015;57:43-9.

230. Maccani JZ, Koestler DC, Lester B, Houseman EA, Armstrong DA, Kelsey KT, et al. Placental DNA methylation related to both infant toenail mercury and adverse neurobehavioral outcomes. Environ Health Perspect. 2015;123(7):723.

231. Bakulski KM, Lee H, Feinberg Jl, Wells EM, Brown S, Herbstman JB, et al. Prenatal mercury concentration is associated with changes in DNA methylation at TCEANC2 in newborns. Int J Epidemiol. 2015;44(4):1249-62.

232. Luyten LJ, Saenen ND, Janssen BG, Vrijens K, Plusquin M, Roels HA, et al. Air pollution and the fetal origin of disease: a systematic review of the molecular signatures of air pollution exposure in human placenta. Environ Res. 2018;166:310-23.

233. Levkovitz R, Zaretsky U, Gordon Z, Jaffa A, Elad D. In vitro simulation of placental transport: part I. Biological model of the placental barrier. Placenta. 2013:34(8):699-707.

234. Nelissen EC, van Montfoort AP, Dumoulin JC, Evers JL. Epigenetics and the placenta. Hum Reprod Update. 2010;17(3):397-417.

235. Gude NM, Roberts CT, Kalionis B, King RG. Growth and function of the normal human placenta. Thromb Res. 2004;114(5-6):397-407.

236. Price EM, Cotton AM, Peñaherrera MS, McFadden DE, Kobor MS, Robinson W. Different measures of "genome-wide" DNA methylation exhibit unique properties in placental and somatic tissues. Epigenetics. 2012;7(6):652-63.

237. Hogg K, Price E, Hanna C, Robinson W. Prenatal and perinatal environmental influences on the human fetal and placental epigenome. Clin Pharmacol Ther. 2012;92(6):716-26.

238. Bollati V, Baccarelli A. Environmental epigenetics. Heredity (Edinb). 2010; 105(1):105.

239. Miska EA, Ferguson-Smith AC. Transgenerational inheritance: models and mechanisms of non-DNA sequence-based inheritance. Science. 2016; 354(6308):59-63.

240. Heard E, Martienssen RA. Transgenerational epigenetic inheritance: myths and mechanisms. Cell. 2014;157(1):95-109.

241. Perera F, Herbstman J. Prenatal environmental exposures, epigenetics, and disease. Reprod Toxicol. 2011;31(3):363-73.

242. Nilsson EE, Skinner MK. Environmentally induced epigenetic transgenerational inheritance of disease susceptibility. Transl Res. 2015; 165(1):12-7

243. Skinner MK. What is an epigenetic transgenerational phenotype?: F3 or F2. Reprod Toxicol. 2008;25(1):2-6.

244. SKinner MK. Metabolic disorders: Fathers' nutritional legacy. Nature. 2010; 467(7318):922 
245. Lahiri DK, Maloney B, Bayon BL, Chopra N, White FA, Greig NH, et al. Transgenerational latent early-life associated regulation unites environment and genetics across generations. Epigenomics. 2016;8(3):373-87.

246. Bruner-Tran KL, Resuehr D, Ding T, Lucas JA, Osteen KG. The role of endocrine disruptors in the epigenetics of reproductive disease and dysfunction: potential relevance to humans. Curr Obstet Gynecol Rep. 2012;1(3):116-23.

247. Manikkam M, Tracey R, Guerrero-Bosagna C, Skinner MK. Plastics derived endocrine disruptors (BPA, DEHP and DBP) induce epigenetic transgenerational inheritance of obesity, reproductive disease and sperm epimutations. PLoS One. 2013;8(1):e55387.

248. Cohen Hubal EA, Moya J, Selevan SG. A lifestage approach to assessing children's exposure. Birth Defects Res Part B: Dev Reprod Toxicol. 2008;83(6):522-9.

249. Zvetkova I, Apedaile A, Ramsahoye B, Mermoud JE, Crompton LA, John R, et al. Global hypomethylation of the genome in XX embryonic stem cells. Nat Genet. 2005:37(11):1274.

250. Nemmar A, Hoylaerts MF, Hoet PH, Nemery B. Possible mechanisms of the cardiovascular effects of inhaled particles: systemic translocation and prothrombotic effects. Toxicol Lett. 2004;149(1-3):243-53.

251. Donaldson K, Stone V, Seaton A, MacNee W. Ambient particle inhalation and the cardiovascular system: potential mechanisms. Environ Health Perspect. 2001;109(Suppl 4):523.

252. Tang WY, Levin L, Talaska G, Cheung YY, Herbstman J, Tang D, et al. Maternal exposure to polycyclic aromatic hydrocarbons and 5'-CpG methylation of interferon- $\gamma$ in cord white blood cells. Environ Health Perspect. 2012;120(8):1195.

253. Okano M, Bell DW, Haber DA, Li E. DNA methyltransferases Dnmt3a and Dnmt3b are essential for de novo methylation and mammalian development. Cell. 1999;99(3):247-57.

254. Valinluck V, Tsai H-H, Rogstad DK, Burdzy A, Bird A, Sowers LC. Oxidative damage to methyl-CpG sequences inhibits the binding of the methyl-CpG binding domain (MBD) of methyl-CpG binding protein 2 (MeCP2). Nucleic Acids Res. 2004;32(14):4100-8.

255. Gaudet F, Hodgson JG, Eden A, Jackson-Grusby L, Dausman J, Gray JW, et al. Induction of tumors in mice by genomic hypomethylation. Science. 2003;300(5618):489-92.

256. Lengauer C, Kinzler KW, Vogelstein B. DNA methylation and genetic instability in colorectal cancer cells. Proc Natl Acad Sci. 1997;94(6):2545-50

257. Chen RZ, Pettersson U, Beard C, Jackson-Grusby L, Jaenisch R. DNA hypomethylation leads to elevated mutation rates. Nature. 1998; 395(6697):89.

258. Yin L-J, Zhang Y, Lv P-P, He W-H, Wu Y-T, Liu A-X, et al. Insufficient maintenance DNA methylation is associated with abnormal embryonic development. BMC Med. 2012;10(1):26.

259. Zhang $X$, Pei L, Li R, Zhang W, Yang H, Li Y, et al. Spina bifida in fetus is associated with an altered pattern of DNA methylation in placenta. J Hum Genet. 2015;60(10):605

260. Rumbajan JM, Yamaguchi Y, Nakabayashi K, Higashimoto $K$, Yatsuki $H$, Nishioka K, et al. The HUS1B promoter is hypomethylated in the placentas of low-birth-weight infants. Gene. 2016:583(2):141-6.

261. Martin EM, Fry RC. A cross-study analysis of prenatal exposures to environmental contaminants and the epigenome: support for stressresponsive transcription factor occupancy as a mediator of gene-specific CpG methylation patterning. Environ Epigenet. 2016;2(1):dvv011.

262. Zhu H, Wang G, Qian J. Transcription factors as readers and effectors of DNA methylation. Nat Rev Genet. 2016;17(9):551.

263. Maleszka R. Epigenetic integration of environmental and genomic signals in honey bees: the critical interplay of nutritional, brain and reproductive networks. Epigenetics. 2008;3(4):188-92.

264. Kucharski R, Maleszka J, Foret S, Maleszka R. Nutritional control of reproductive status in honeybees via DNA methylation. Science. 2008; 319(5871):1827-30.

265. Rogic S, Wong A, Pavlidis P. Meta-analysis of gene expression patterns in animal models of prenatal alcohol exposure suggests role for protein synthesis inhibition and chromatin remodeling. Alcohol Clin Exp Res. 2016:40(4):717-27.

266. Chiva-Blanch G, Badimon L. Effects of polyphenol intake on metabolic syndrome: current evidences from human trials. Oxidative Med Cell Longev. 2017;2017:5812401.

267. Chiva-Blanch G, Visioli F. Polyphenols and health: moving beyond antioxidants. J Berry Res. 2012;2(2):63-71.

268. Kala $\mathrm{R}$, Tollefsbol TO. A novel combinatorial epigenetic therapy using resveratrol and pterostilbene for restoring estrogen receptor-alpha (ERalpha) expression in ERalpha-negative breast cancer cells. PLoS One. 2016;11(5): e0155057.

269. Royston KJ, Paul B, Nozell S, Rajbhandari R, Tollefsbol TO. Withaferin A and sulforaphane regulate breast cancer cell cycle progression through epigenetic mechanisms. Exp Cell Res. 2018;368(1):67-74.

270. Choi K-C, Jung MG, Lee Y-H, Yoon JC, Kwon SH, Kang H-B, et al. Epigallocatechin-3-gallate, a histone acetyltransferase inhibitor, inhibits EBVinduced B lymphocyte transformation via suppression of RelA acetylation. Cancer Res. 2009;69(2):583-92.

271. Guo X, Cai Q, Bao P, Wu J, Wen W, Ye F, et al. Long-term soy consumption and tumor tissue MicroRNA and gene expression in triple-negative breast cancer. Cancer. 2016;122(16):2544-51.

272. Graham HN. Green tea composition, consumption, and polyphenol chemistry. Prev Med. 1992;21(3):334-50.

273. Lin J-K, Liang Y-C, Lin-Shiau S-Y. Cancer chemoprevention by tea polyphenols through mitotic signal transduction blockade. Biochem Pharmacol. 1999:58(6):911-5.

274. Fang MZ, Wang Y, Ai N, Hou Z, Sun Y, Lu H, et al. Tea polyphenol (-)-epigallocatechin-3-gallate inhibits DNA methyltransferase and reactivates methylation-silenced genes in cancer cell lines. Cancer Res. 2003;63(22): 7563-70.

275. Lee WJ, Shim J-Y, Zhu BT. Mechanisms for the inhibition of DNA methyltransferases by tea catechins and bioflavonoids. Mol Pharmacol. 2005;68(4):1018-30.

276. Li Y, Meeran SM, Tollefsbol TO. Combinatorial bioactive botanicals resensitize tamoxifen treatment in ER-negative breast cancer via epigenetic reactivation of ERalpha expression. Sci Rep. 2017;7(1):9345.

277. Balasubramanian S, Adhikary G, Eckert RL. The Bmi-1 polycomb protein antagonizes the (-)-epigallocatechin-3-gallate-dependent suppression of skin cancer cell survival. Carcinogenesis. 2009;31(3):496-503.

278. Li B-B, Huang G-L, Li H-H, Kong X, He Z-W. Epigallocatechin-3-gallate modulates microrna expression profiles in human nasopharyngeal carcinoma CNE2 cells. Chin Med J. 2017;130(1):93.

279. Rasheed Z, Rasheed N, Al-Shaya O. Epigallocatechin-3-O-gallate modulates global microRNA expression in interleukin-1 $\beta$-stimulated human osteoarthritis chondrocytes: potential role of EGCG on negative co-regulation of microRNA140-3p and ADAMTS5. Eur J Nutr. 2018;57(3):917-28.

280. Zhu K, Wang W. Green tea polyphenol EGCG suppresses osteosarcoma cell growth through upregulating miR-1. Tumor Biol. 2016;37(4):4373-82.

281. Qian B-J, Tian C-C, Ling X-H, Yu L-L, Ding F-Y, Huo J-H, et al. miRNA-150-5p associate with antihypertensive effect of epigallocatechin-3-gallate revealed by aorta miRNome analysis of spontaneously hypertensive rat. Life Sci. 2018; 203:193-202.

282. Das DK, Mukherjee S, Ray D. Erratum to: resveratrol and red wine, healthy heart and longevity. Heart Fail Rev. 2011;16(4):425-35.

283. Gao Y, Tollefsbol TO. Combinational proanthocyanidins and resveratrol synergistically inhibit human breast cancer cells and impact epigenetic (-) mediating machinery. Int J Mol Sci. 2018;19(8):2204.

284. Qin W, Zhang K, Clarke K, Weiland T, Sauter ER. Methylation and miRNA effects of resveratrol on mammary tumors vs. normal tissue. Nutr Cancer. 2014;66(2):270-7.

285. Mirza S, Sharma G, Parshad R, Gupta SD, Pandya P, Ralhan R. Expression of DNA methyltransferases in breast cancer patients and to analyze the effect of natural compounds on DNA methyltransferases and associated proteins. J Breast Cancer. 2013;16(1):23-31.

286. Papoutsis AJ, Lamore SD, Wondrak GT, Selmin OI, Romagnolo DF. Resveratrol prevents epigenetic silencing of BRCA-1 by the aromatic hydrocarbon receptor in human breast cancer cells. J Nutr. 2010;140(9):1607-14.

287. Tsai R-Y, Wang J-C, Chou K-Y, Wong C-S, Cherng C-H. Resveratrol reverses morphine-induced neuroinflammation in morphine-tolerant rats by reversal HDAC1 expression. J Formos Med Assoc. 2016;115(6):445-54.

288. Venturelli S, Berger A, Böcker A, Busch C, Weiland T, Noor S, et al. Resveratrol as a pan-HDAC inhibitor alters the acetylation status of jistone proteins in humanderived hepatoblastoma cells. PLoS One. 2013;8(8):e73097.

289. Dayangaç-Erden D, Bora G, Ayhan P, Kocaefe Ç, Dalkara S, Yelekçi K, et al. Histone deacetylase inhibition activity and molecular docking of (e)resveratrol: its therapeutic potential in spinal muscular atrophy. Chem Biol Drug Des. 2009:73(3):355-64.

290. Kang H, Oka S, Lee D-Y, Park J, Aponte AM, Jung Y-S, et al. Sirt1 carboxyldomain is an ATP-repressible domain that is transferrable to other proteins. Nat Commun. 2017:8:15560. 
291. Peng L, Yuan Z, Ling H, Fukasawa K, Robertson K, Olashaw N, et al. SIRT1 deacetylates the DNA methyltransferase 1 (DNMT1) protein and alters its activities. Mol Cell Biol. 2011;31:06147-11.

292. Cao W, Dou Y, Li A. Resveratrol boosts cognitive function by targeting SIRT1. Neurochem Res. 2018;43:1-9.

293. Lagouge M, Argmann C, Gerhart-Hines Z, Meziane H, Lerin C, Daussin F, et al. Resveratrol improves mitochondrial function and protects against metabolic disease by activating SIRT1 and PGC-1a. Cell. 2006;127(6):1109-22.

294. Borra MT, Smith BC, Denu JM. Mechanism of human SIRT1 activation by resveratrol. J Biol Chem. 2005;280(17):17187-95.

295. Zhu X, Liu Q, Wang M, Liang M, Yang X, Xu X, et al. Activation of Sirt1 by resveratrol inhibits TNF-a induced inflammation in fibroblasts. PLoS One. 2011;6(11):e27081.

296. Lei M, Wang J-G, Xiao D-M, Fan M, Wang D-P, Xiong J-Y, et al. Resveratrol inhibits interleukin $1 \beta$-mediated inducible nitric oxide synthase expression in articular chondrocytes by activating SIRT1 and thereby suppressing nuclear factor-kB activity. Eur J Pharmacol. 2012;674(2):73-9.

297. Hubbard BP, Sinclair DA. Small molecule SIRT1 activators for the treatment of aging and age-related diseases. Trends Pharmacol Sci. 2014;35(3):146-54.

298. Cao D, Wang M, Qiu X, Liu D, Jiang H, Yang N, et al. Structural basis for allosteric, substrate-dependent stimulation of SIRT1 activity by resveratrol. Genes Dev. 2015;29(12):1316-25.

299. Zhang Y, Du X, Li W, Sang H, Qian A, Sun L, et al. Resveratrol improves endothelial progenitor cell function through miR-138 by targeting focal adhesion kinase (FAK) and promotes thrombus resolution in vivo. Med Sci Monit: international medical journal of experimental and clinical research. 2018:24:951

300. Xin Y, Zhang H, Jia Z, Ding X, Sun Y, Wang Q, et al. Resveratrol improves uric acid-induced pancreatic $\beta$-cells injury and dysfunction through regulation of miR-126. Biomed Pharmacother. 2018;102:1120-6.

301. Yan B, Cheng L, Jiang Z, Chen K, Zhou C, Sun L, et al. Resveratrol inhibits ROS-promoted activation and glycolysis of pancreatic stellate cells via suppression of miR-21. Oxidative Med Cell Longev. 2018;2018:1346958.

302. Jin $\mathrm{H}$, Zhang $\mathrm{H}$, Ma T, Lan $\mathrm{H}$, Feng $\mathrm{S}$, Zhu H, et al. Resveratrol protects murine chondrogenic ATDC5 cells against LPS-induced inflammatory injury through up-regulating MiR-146b. Cell Physiol Biochem. 2018;47(3):972-80.

303. Wang $X$, Zhang Y. Resveratrol alleviates LPS-induced injury in human keratinocyte cell line $\mathrm{HaCaT}$ by up-regulation of miR-17. Biochem Biophys Res Commun. 2018;501(1):106-12.

304. Dixon RA, Ferreira D. Genistein. Phytochemistry. 2002;60(3):205-11.

305. Mukund V, Mukund D, Sharma V, Mannarapu M, Alam A. Genistein: its role in metabolic diseases and cancer. Crit Rev Oncol Hematol. 2017:119:13-22.

306. Sundaram MK, Ansari MZ, Al Mutery A, Ashraf M, Nasab R, Rai S, et al. Genistein induces alterations of epigenetic modulatory signatures in human cervical cancer cells. Anti-Cancer Agents Med Chem (Formerly Current Medicinal Chemistry-Anti-Cancer Agents). 2018;18(3):412-21.

307. Sanaei M, Kavoosi F, Salehi H. Genistein and trichostatin a induction of estrogen receptor alpha gene expression, apoptosis and cell growth inhibition in hepatocellular carcinoma HepG 2 cells. Asian Pac J Cancer Prev: APJCP. 2017;18(12):3445.

308. Xie Q, Bai Q, Zou LY, Zhang QY, Zhou Y, Chang H, et al. Genistein inhibits DNA methylation and increases expression of tumor suppressor genes in human breast cancer cells. Genes Chromosomes Cancer. 2014; 53(5):422-31.

309. Li Y, Meeran SM, Patel SN, Chen H, Hardy TM, Tollefsbol TO. Epigenetic reactivation of estrogen receptor-alpha (ERalpha) by genistein enhances hormonal therapy sensitivity in ERalpha-negative breast cancer. Mol Cancer. 2013;12:9.

310. Zhang Y, Li Q, Chen H. DNA methylation and histone modifications of Wnt genes by genistein during colon cancer development. Carcinogenesis. 2013; 34(8):1756-63.

311. Majid S, Dar AA, Shahryari V, Hirata H, Ahmad A, Saini S, et al. Genistein reverses hypermethylation and induces active histone modifications in tumor suppressor gene B-cell translocation gene 3 in prostate cancer. Cancer: Interdisciplinary International Journal of the American Cancer Society. 2010;116(1):66-76.

312. Qin W, Zhu W, Shi H, Hewett JE, Ruhlen RL, MacDonald RS, et al. Soy isoflavones have an antiestrogenic effect and alter mammary promoter hypermethylation in healthy premenopausal women. Nutr Cancer. 2009; 61(2):238-44.

313. Majid S, Dar AA, Ahmad AE, Hirata H, Kawakami K, Shahryari V, et al. BTG3 tumor suppressor gene promoter demethylation, histone modification and cell cycle arrest by genistein in renal cancer. Carcinogenesis. 2009;30(4):662-70.

314. Majid S, Kikuno N, Nelles J, Noonan E, Tanaka Y, Kawamoto K, et al. Genistein induces the p21WAF1/CIP1 and p16INK4a tumor suppressor genes in prostate cancer cells by epigenetic mechanisms involving active chromatin modification. Cancer Res. 2008:68(8):2736-44.

315. Kikuno N, Shiina H, Urakami S, Kawamoto K, Hirata H, Tanaka Y, et al. Retracted: genistein mediated histone acetylation and demethylation activates tumor suppressor genes in prostate cancer cells. Int J Cancer. 2008;123(3):552-60.

316. Fang MZ, Chen D, Sun Y, Jin Z, Christman JK, Yang CS. Reversal of hypermethylation and reactivation of p16INK4a, RARB, and MGMT genes by genistein and other isoflavones from soy. Clin Cancer Res. 2005; 11(19):7033-41.

317. Li Y, Liu L, Andrews LG, Tollefsbol TO. Genistein depletes telomerase activity through cross-talk between genetic and epigenetic mechanisms. Int J Cancer. 2009;125(2):286-96.

318. Hirata H, Hinoda Y, Shahryari V, Deng G, Tanaka Y, Tabatabai Z, et al. Genistein downregulates onco-miR-1260b and upregulates sFRP1 and Smad4 via demethylation and histone modification in prostate cancer cells. Br J Cancer. 2014;110(6):1645

319. Qin J, Chen JX, Zhu Z, Teng JA. Genistein inhibits human colorectal cancer growth and suppresses miR-95, Akt and SGK1. Cell Physiol Biochem. 2015; 35(5):2069-77.

320. Chiyomaru T, Yamamura S, Fukuhara S, Hidaka H, Majid S, Saini S, et al. Genistein up-regulates tumor suppressor microRNA-574-3p in prostate cancer. PLoS One. 2013;8(3):e58929.

321. Zaman MS, Thamminana S, Shahryari V, Chiyomaru T, Deng G, Saini S, et al. Inhibition of PTEN gene expression by oncogenic miR-23b-3p in renal cancer. PLoS One. 2012:7(11):e50203.

322. Marfe G, Tafani M, Indelicato M, Sinibaldi-Salimei P, Reali V, Pucci B, et al. Kaempferol induces apoptosis in two different cell lines via Akt inactivation, Bax and SIRT3 activation, and mitochondrial dysfunction. J Cell Biochem. 2009:106(4):643-50

323. Berger A, Venturelli S, Kallnischkies M, Böcker A, Busch C, Weiland T, et al. Kaempferol, a new nutrition-derived pan-inhibitor of human histone deacetylases. J Nutr Biochem. 2013;24(6):977-85.

324. Kim TW, Lee SY, Kim M, Cheon C, Ko S-G. Kaempferol induces autophagic cell death via IRE1-JNK-CHOP pathway and inhibition of G9a in gastric cancer cells. Cell Death Dis. 2018;9(9):875.

325. Paluszczak J, Krajka-Kuźniak V, Baer-Dubowska W. The effect of dietary polyphenols on the epigenetic regulation of gene expression in MCF7 breast cancer cells. Toxicol Lett. 2010;192(2):119-25.

326. Fang $M$, Chen D, Yang CS. Dietary polyphenols may affect DNA methylation. J Nutr. 2007;137(1):223S-8S.

327. Kanwal R, Datt M, Liu X, Gupta S. Dietary flavones as dual inhibitors of DNA methyltransferases and histone methyltransferases. PLoS One. 2016;11(9): e0162956.

328. Krifa M, Leloup L, Ghedira K, Mousli M, Chekir-Ghedira L. Luteolin induces apoptosis in BE colorectal cancer cells by downregulating calpain, UHRF1, and DNMT1 expressions. Nutr Cancer. 2014;66(7):1220-7.

329. Kim A, Yun J-M. Combination treatments with luteolin and fisetin enhance anti-inflammatory effects in high glucose-treated THP-1 cells through histone acetyltransferase/histone deacetylase regulation. J Med Food. 2017;20(8):782-9.

330. Zuo Q, Wu R, Xiao X, Yang C, Yang Y, Wang C, et al. The dietary flavone luteolin epigenetically activates the Nrf2 pathway and blocks cell transformation in human colorectal cancer HCT116 cells. J Cell Biochem. 2018;119(11):9573-82.

331. Fernández-Bedmar Z, Anter J, Alonso-Moraga A, Martín de las Mulas J, Millán-Ruiz Y, Guil-Luna S. Demethylating and anti-hepatocarcinogenic potential of hesperidin, a natural polyphenol of Citrus juices. Mol Carcinog. 2017:56(6):1653-62

332. Tan S, Wang C, Lu C, Zhao B, Cui Y, Shi X, et al. Quercetin is able to demethylate the p16INK4a gene promoter. Chemotherapy. 2009;55(1):6-10.

333. Wood JG, Rogina B, Lavu S, Howitz K, Helfand SL, Tatar M, et al. Sirtuin activators mimic caloric restriction and delay ageing in metazoans. Nature. 2004:430(7000):686.

334. Ruiz PA, Braune A, Hölzlwimmer G, Quintanilla-Fend L, Haller D. Quercetin inhibits TNF-induced NF-K B transcription factor recruitment to proinflammatory gene promoters in murine intestinal epithelial cells. J Nutr. 2007;137(5):1208-15. 
335. Bora-Tatar G, Dayangaç-Erden D, Demir AS, Dalkara S, Yelekçi K, ErdemYurter H. Molecular modifications on carboxylic acid derivatives as potent histone deacetylase inhibitors: activity and docking studies. Bioorg Med Chem. 2009;17(14):5219-28.

336. Waldecker M, Kautenburger T, Daumann H, Busch C, Schrenk D. Inhibition of histone-deacetylase activity by short-chain fatty acids and some polyphenol metabolites formed in the colon. J Nutr Biochem. 2008;19(9):587-93.

337. Nian H, Delage B, Pinto JT, Dashwood RH. Allyl mercaptan, a garlic-derived organosulfur compound, inhibits histone deacetylase and enhances Sp3 binding on the P21WAF1 promoter. Carcinogenesis. 2008;29(9):1816-24.

338. Lee J-H, Kim K-A, Kwon K-B, Kim E-K, Lee Y-R, Song M-Y, et al. Diallyl disulfide accelerates adipogenesis in 3T3-L1 cells. Int J Mol Med. 2007;20(1): 59-64.

339. Arunkumar A, Vijayababu MR, Gunadharini N, Krishnamoorthy G, Arunakaran J. Induction of apoptosis and histone hyperacetylation by diallyl disulfide in prostate cancer cell line PC-3. Cancer Lett. 2007;251(1):59-67.

340. Druesne N, Pagniez A, Mayeur C, Thomas M, Cherbuy C, DuËe P-H, et al. Diallyl disulfide (DADS) increases histone acetylation and p21 waf1/cip1 expression in human colon tumor cell lines. Carcinogenesis. 2004;25(7): 1227-36.

341. Wang L-S, Kuo C-T, Cho S-J, Seguin C, Siddiqui J, Stoner K, et al. Black raspberry-derived anthocyanins demethylate tumor suppressor genes through the inhibition of DNMT1 and DNMT3B in colon cancer cells. Nutr Cancer. 2013;65(1):118-25.

342. Arola-Arnal A, Blade C. Proanthocyanidins modulate microRNA expression in human HepG2 cells. PLoS One. 2011;6(10):e25982.

343. Hong K-S, Park J-I, Kim M-J, Kim H-B, Lee J-W, Dao TT, et al. Involvement of SIRT1 in hypoxic down-regulation of c-Myc and $\beta$-catenin and hypoxic preconditioning effect of polyphenols. Toxicol Appl Pharmacol. 2012;259(2): 210-8.

344. Howitz KT, Bitterman KJ, Cohen HY, Lamming DW, Lavu S, Wood JG, et al. Small molecule activators of sirtuins extend Saccharomyces cerevisiae lifespan. Nature. 2003;425(6954):191.

345. Zhang J, Huang Y, Shao H, Bi Q, Chen J, Ye Z. Grape seed procyanidin B2 inhibits adipogenesis of 3T3-L1 cells by targeting peroxisome proliferatoractivated receptor $\gamma$ with miR-483-5p involved mechanism. Biomed Pharmacother. 2017;86:292-6.

346. Aragonès $G$, Suárez $M$, Ardid-Ruiz A, Vinaixa M, Rodríguez MA, Correig X, et al. Dietary proanthocyanidins boost hepatic NAD+ metabolism and SIRT1 expression and activity in a dose-dependent manner in healthy rats. Sci Rep. 2016;6:24977.

347. Lee YA, Cho EJ, Yokozawa T. Protective effect of persimmon (Diospyros kaki) peel proanthocyanidin against oxidative damage under $\mathrm{H} 2 \mathrm{O} 2$-induced cellular senescence. Biol Pharm Bull. 2008;31(6):1265-9.

348. Baselga-Escudero L, Blade C, Ribas-Latre A, Casanova E, Salvadó M-J, Arola L, et al. Chronic supplementation of proanthocyanidins reduces postprandial lipemia and liver miR-33a and miR-122 levels in a dose-dependent manner in healthy rats. J Nutr Biochem. 2014;25(2):151-6.

349. Cosio BG, Tsaprouni L, Ito K, Jazrawi E, Adcock IM, Barnes PJ. Theophylline restores histone deacetylase activity and steroid responses in COPD macrophages. J Exp Med. 2004;200(5):689-95.

350. Ito K, Lim S, Caramori G, Cosio B, Chung KF, Adcock IM, et al. A molecular mechanism of action of theophylline: induction of histone deacetylase activity to decrease inflammatory gene expression. Proc Natl Acad Sci. 2002; 99(13):8921-6

351. Guerrero-Bosagna CM, Sabat P, Valdovinos FS, Valladares LE, Clark SJ. Epigenetic and phenotypic changes result from a continuous pre and post natal dietary exposure to phytoestrogens in an experimental population of mice. BMC Physiol. 2008;8(1):17.

352. Bosviel R, Durif J, Déchelotte P, Bignon Y-J, Bernard-Gallon D. Epigenetic modulation of BRCA1 and BRCA2 gene expression by equol in breast cancer cell lines. Br J Nutr. 2012;108(7):1187-93.

353. Nagaraju GP, Zhu S, Wen J, Farris AB, Adsay VN, Diaz R, et al. Novel synthetic curcumin analogues EF31 and UBS109 are potent DNA hypomethylating agents in pancreatic cancer. Cancer Lett. 2013;341(2):195-203.

354. Zhu X, Li Q, Chang R, Yang D, Song Z, Guo Q, et al. Curcumin alleviates neuropathic pain by inhibiting p300/CBP histone acetyltransferase activityregulated expression of BDNF and cox-2 in a rat model. PLoS One. 2014; 9(3):e91303.

355. Roy M, Mukherjee $\mathrm{S}$. Reversal of resistance towards cisplatin by curcumin in cervical cancer cells. Asian Pac J Cancer Prev. 2014;15(3):1403-10.
356. Shu L, Khor TO, Lee J-H, Boyanapalli SS, Huang Y, Wu T-Y, et al. Epigenetic $\mathrm{CpG}$ demethylation of the promoter and reactivation of the expression of Neurog1 by curcumin in prostate LNCaP cells. AAPS J. 2011;13(4):606-14.

357. Mirzaei H, Masoudifar A, Sahebkar A, Zare N, Sadri Nahand J, Rashidi B, et al. MicroRNA: a novel target of curcumin in cancer therapy. J Cell Physiol. 2018; 233(4):3004-15.

358. Camarena V, Wang G. The epigenetic role of vitamin C in health and disease. Cell Mol Life Sci. 2016;73(8):1645-58.

359. Gould BS, WOESSNKER J. Biosynthesis of collagen. The influence of ascorbic acid on the proline, hydroxyproline, glycine and collagen content of regenerating guinea pig skin. J Biol Chem. 1957;226:289-300.

360. Young Jl, Züchner S, Wang G. Regulation of the epigenome by vitamin C. Annu Rev Nutr. 2015;35:545-64.

361. Dickson KM, Gustafson CB, Young Jl, Züchner S, Wang G. Ascorbate-induced generation of 5-hydroxymethylcytosine is unaffected by varying levels of iron and 2-oxoglutarate. Biochem Biophys Res Commun. 2013;439(4):522-7.

362. Minor EA, Young Jl, Wang G. Ascorbate induces ten-eleven translocation (Tet) methylcytosine dioxygenase-mediated generation of 5hydroxymethylcytosine. J Biol Chem. 2013;288(19):13669-74.

363. Yin R, Mao S-Q, Zhao B, Chong Z, Yang Y, Zhao C, et al. Ascorbic acid enhances Tet-mediated 5-methylcytosine oxidation and promotes DNA demethylation in mammals. J Am Chem Soc. 2013;135(28):10396-403.

364. Chen J, Guo L, Zhang L, Wu H, Yang J, Liu H, et al. Vitamin C modulates TET1 function during somatic cell reprogramming. Nat Genet. 2013;45(12):1504.

365. Nair VS, Song MH, Oh KI. Vitamin C facilitates demethylation of the Foxp3 enhancer in a Tet-dependent manner. J Immunol. 2016;196:1502352.

366. Blaschke K, Ebata KT, Karimi MM, Zepeda-Martínez JA, Goyal P, Mahapatra S, et al. Vitamin C induces Tet-dependent DNA demethylation and a blastocyst-like state in ES cells. Nature. 2013;500(7461):222.

367. Chen J, Liu H, Liu J, Qi J, Wei B, Yang J, et al. H3K9 methylation is a barrier during somatic cell reprogramming into iPSCs. Nat Genet. 2013;45(1):34.

368. Ebata KT, Mesh K, Liu S, Bilenky M, Fekete A, Acker MG, et al. Vitamin C induces specific demethylation of $\mathrm{H3K9me2} \mathrm{in} \mathrm{mouse} \mathrm{embryonic} \mathrm{stem} \mathrm{cells}$ via Kdm3a/b. Epigenetics Chromatin. 2017;10(1):36.

369. Wang T, Chen K, Zeng X, Yang J, Wu Y, Shi X, et al. The histone demethylases $\mathrm{Jhdm} 1 \mathrm{a} / \mathrm{lb}$ enhance somatic cell reprogramming in a vitamin-C-dependent manner. Cell Stem Cell. 2011;9(6):575-87.

370. Klose RJ, Yamane K, Bae Y, Zhang D, Erdjument-Bromage $H$, Tempst $P$, et al. The transcriptional repressor JHDM3A demethylates trimethyl histone $\mathrm{H3}$ lysine 9 and lysine 36. Nature. 2006:442(7100):312.

371. Tsukada Y-I, Fang J, Erdjument-Bromage H, Warren ME, Borchers CH, Tempst $\mathrm{P}$, et al. Histone demethylation by a family of JmjC domain-containing proteins. Nature. 2006;439(7078):811.

372. Fetahu IS, Höbaus J, Kállay E. Vitamin D and the epigenome. Front Physiol. 2014;5:164.

373. Moore DD, Kato S, Xie W, Mangelsdorf DJ, Schmidt DR, Xiao R, et al. International Union of Pharmacology. LXII. The NR1H and NR1I receptors: constitutive androstane receptor, pregnene $X$ receptor, farnesoid $X$ receptor $\alpha$, farnesoid $X$ receptor $\beta$, liver $X$ receptor $a$, liver $X$ receptor $\beta$, and vitamin D receptor. Pharmacol Rev. 2006;58(4):742-59.

374. Seuter S, Pehkonen P, Heikkinen S, Carlberg C. Dynamics of 1a, 25dihydroxyvitamin D 3-dependent chromatin accessibility of early vitamin D receptor target genes. Biochim Biophys Acta (BBA)-Gene Regulatory Mechanisms. 2013;1829(12):1266-75.

375. Tapp HS, Commane DM, Bradburn DM, Arasaradnam R, Mathers JC, Johnson IT, et al. Nutritional factors and gender influence age-related DNA methylation in the human rectal mucosa. Aging Cell. 2013;12(1):148-55.

376. Rawson JB, Sun Z, Dicks E, Daftary D, Parfrey PS, Green RC, et al. Vitamin D intake is negatively associated with promoter methylation of the Wnt antagonist gene DKK1 in a large group of colorectal cancer patients. Nutr Cancer. 2012;64(7):919-28.

377. Lopes N, Carvalho J, Duraes C, Sousa B, Gomes M, Costa JL, et al. 1Alpha, 25-dihydroxyvitamin D3 induces de novo E-cadherin expression in triplenegative breast cancer cells by $\mathrm{CDH1}$-promoter demethylation. Anticancer Res. 2012;32(1):249-57.

378. Vanoirbeek E, Eelen G, Verlinden L, Carmeliet G, Mathieu C, Bouillon R, et al. PDLIM2 expression is driven by vitamin $D$ and is involved in the proadhesion, and anti-migration and-invasion activity of vitamin D. Oncogene. 2014;33(15):1904.

379. Doig CL, Singh PK, Dhiman VK, Thorne JL, Battaglia S, Sobolewski M, et al. Recruitment of NCOR1 to VDR target genes is enhanced in prostate cancer 
cells and associates with altered DNA methylation patterns. Carcinogenesis. 2012;34(2):248-56.

380. Fu B, Wang H, Wang J, Barouhas I, Liu W, Shuboy A, et al. Epigenetic regulation of BMP2 by 1, 25-dihydroxyvitamin D3 through DNA methylation and histone modification. PLoS One. 2013;8(4):e61423.

381. Tan J, Lu J, Huang W, Dong Z, Kong C, Li L, et al. Genome-wide analysis of histone $\mathrm{H} 3$ lysine9 modifications in human mesenchymal stem cell osteogenic differentiation. PLoS One. 2009;4(8):e6792.

382. Zeljic K, Supic G, Magic Z. New insights into vitamin D anticancer properties: focus on miRNA modulation. Mol Gen Genomics. 2017;292(3): $511-24$.

383. Kok DE, Steegenga WT, McKay JA. Folate and epigenetics: why we should not forget bacterial biosynthesis. In: Future Medicine; 2018.

384. Li S, Zhi L, Liu Y, Shen J, Liu L, Yao J, et al. Effect of in ovo feeding of folic acid on the folate metabolism, immune function and epigenetic modification of immune effector molecules of broiler. Br J Nutr. 2016;115(3): 411-21.

385. Smith AD, Kim Y-I, Refsum H. Is folic acid good for everyone? Am J Clin Nutr. 2008:87(3):517-33.

386. Bailey LB, Stover PJ, McNulty H, Fenech MF, Gregory JF III, Mills JL, et al. Biomarkers of nutrition for development-folate review-5. J Nutr. 2015; 145(7):1636S-80S.

387. Winter-Vann AM, Kamen BA, Bergo MO, Young SG, Melnyk S, James SJ, et al. Targeting Ras signaling through inhibition of carboxyl methylation: an unexpected property of methotrexate. Proc Natl Acad Sci. 2003;100(11):6529-34.

388. Cravo M, Pinto A, Chaves P, Cruz J, Lage P, Leitão CN, et al. Effect of folate supplementation on DNA methylation of rectal mucosa in patients with colonic adenomas: correlation with nutrient intake. Clin Nutr. 1998;17(2):45-9.

389. Oltean S, Banerjee R. Nutritional modulation of gene expression and homocysteine utilization by vitamin B12. J Biol Chem. 2003;278(23):20778-84.

390. Savage DG, Lindenbaum J, Stabler SP, Allen RH. Sensitivity of serum methylmalonic acid and total homocysteine determinations for diagnosing cobalamin and folate deficiencies. Am J Med. 1994;96(3):239-46.

391. Stover PJ. One-carbon metabolism-genome interactions in folate-associated pathologies. J Nutr. 2009;139(12):2402-5.

392. Zeisel S. Choline, other methyl-donors and epigenetics. Nutrients. 2017;9(5):445.

393. Wolff GL, Kodell RL, Moore SR, Cooney CA. Maternal epigenetics and methyl supplements affect agouti gene expression in a vy/a mice. FASEB J. 1998; 12(11):949-57.

394. Cooney CA, Dave AA, Wolff GL. Maternal methyl supplements in mice affect epigenetic variation and DNA methylation of offspring. J Nutr. 2002;132(8): 2393S-400S

395. Waterland RA, Dolinoy DC, Lin JR, Smith CA, Shi X, Tahiliani KG. Maternal methyl supplements increase offspring DNA methylation at Axin Fused. Genesis. 2006;44(9):401-6.

396. DeChiara TM, Robertson EJ, Efstratiadis A. Parental imprinting of the mouse insulin-like growth factor II gene. Cell. 1991;64(4):849-59.

397. Cordero P, Campion J, Milagro Fl, Martinez JA. Transcriptomic and epigenetic changes in early liver steatosis associated to obesity: effect of dietary methyl donor supplementation. Mol Genet Metab. 2013;110(3):388-95.

398. Cordero P, Gómez-Úriz AM, Campion J, Milagro F, Martinez JA. Dietary supplementation with methyl donors reduces fatty liver and modifies the fatty acid synthase DNA methylation profile in rats fed an obesogenic diet. Genes Nutr. 2013;8(1):105.

399. Schroeder H, Hoeltken A, Fladung M. Differentiation of Populus species using chloroplast single nucleotide polymorphism (SNP) markers-essential for comprehensible and reliable poplar breeding. Plant Biol. 2012;14(2):374-81.

400. Sun S, Li X, Ren A, Du M, Du H, Shu Y, et al. Choline and betaine consumption lowers cancer risk: a meta-analysis of epidemiologic studies. Sci Rep. 2016;6:35547.

401. Tsujiuchi T, Tsutsumi M, Sasaki Y, Takahama M, Konishi Y. Hypomethylation of $\mathrm{CpG}$ sites and c-myc gene overexpression in hepatocellular carcinomas, but not hyperplastic nodules, induced by a choline-deficient L-amino aciddefined diet in rats. Jpn J Cancer Res. 1999:90(9):909-13.

402. Pogribny IP, Pogribna M, Christman JK, James SJ. Single-site methylation within the p53 promoter region reduces gene expression in a reporter gene construct: possible in vivo relevance during tumorigenesis. Cancer Res. 2000;60(3):588-94.

403. Pogribny IP, James SJ. De novo methylation of the p16INK4A gene in early preneoplastic liver and tumors induced by folate/methyl deficiency in rats. Cancer Lett. 2002;187(1-2):69-75.
404. Tsujiuchi T, Shimizu K, Itsuzaki Y, Onishi M, Sugata E, Fujii H, et al. CpG site hypermethylation of E-cadherin and Connexin26 genes in hepatocellular carcinomas induced by a choline-deficient L-amino acid-defined diet in rats. Mol Carcinog: Published in cooperation with the University of Texas MD Anderson Cancer Center. 2007;46(4):269-74.

405. Pogribny IP, James SJ, Beland FA. Molecular alterations in hepatocarcinogenesis induced by dietary methyl deficiency. Mol Nutr Food Res. 2012;56(1):116-25.

406. Balaraman S, Idrus NM, Miranda RC, Thomas JD. Postnatal choline supplementation selectively attenuates hippocampal microRNA alterations associated with developmental alcohol exposure. Alcohol. 2017;60:159-67.

407. Trujillo-Gonzalez I, Wang Y, Friday WB, Vickers KC, Toth CL, Molina-Torres L, et al. microRNA-129-5p is regulated by choline availability and controls EGF receptor synthesis and neurogenesis in the cerebral cortex. FASEB J. 2018; 33(3):3601-12.

408. Gamet-Payrastre L, Li P, Lumeau S, Cassar G, Dupont M-A, Chevolleau S, et al. Sulforaphane, a naturally occurring isothiocyanate, induces cell cycle arrest and apoptosis in HT29 human colon cancer cells. Cancer Res. 2000; 60(5):1426-33.

409. Paul B, Li Y, Tollefsbol TO. The effects of combinatorial genistein and sulforaphane in breast tumor inhibition: role in epigenetic regulation. Int J Mol Sci. 2018;19(6):1754

410. Martin SL, Kala R, Tollefsbol TO. Mechanisms for the inhibition of colon cancer cells by sulforaphane through epigenetic modulation of microRNA21 and human telomerase reverse transcriptase (hTERT) down-regulation. Curr Cancer Drug Targets. 2018;18(1):97-106.

411. Royston K, Udayakumar N, Lewis K, Tollefsbol TO. A novel combination of withaferin $A$ and sulforaphane inhibits epigenetic machinery, cellular viability and induces apoptosis of breast cancer cells. Int J Mol Sci. 2017;18(5):1092.

412. Jiang L-L, Zhou S-J, Zhang X-M, Chen H-Q, Liu W. Sulforaphane suppresses in vitro and in vivo lung tumorigenesis through downregulation of HDAC activity. Biomed Pharmacother. 2016;78:74-80.

413. Gräff J, Tsai L-H. Histone acetylation: molecular mnemonics on the chromatin. Nat Rev Neurosci. 2013;14(2):97.

414. Gao L, Cheng D, Yang J, Wu R, Li W, Kong A-N. Sulforaphane epigenetically demethylates the $\mathrm{CpG}$ sites of the miR-9-3 promoter and reactivates miR-9-3 expression in human lung cancer A549 cells. J Nutr Biochem. 2018;56:109-15.

415. Fan $H$, Zhang R, Tesfaye D, Tholen E, Looft C, Hölker M, et al. Sulforaphane causes a major epigenetic repression of myostatin in porcine satellite cells. Epigenetics. 2012;7(12):1379-90.

416. Liu C-M, Peng C-Y, Liao Y-W, Lu M-Y, Tsai M-L, Yeh J-C, et al. Sulforaphane targets cancer stemness and tumor initiating properties in oral squamous cell carcinomas via miR-200c induction. J Formos Med Assoc. 2017;116(1):41-8.

417. Zhu J, Wang $S$, Chen $Y$, Li X, Jiang $Y$, Yang $X$, et al. miR-19 targeting of GSK3ß mediates sulforaphane suppression of lung cancer stem cells. J Nutr Biochem. 2017:44:80-91.

418. Beaver LM, Kuintzle R, Buchanan A, Wiley MW, Glasser ST, Wong CP, et al. Long noncoding RNAs and sulforaphane: a target for chemoprevention and suppression of prostate cancer. J Nutr Biochem. 2017;42:72-83.

419. Beklemisheva AA, Fang Y, Feng J, Ma X, Dai W, Chiao JW. Epigenetic mechanism of growth inhibition induced by phenylhexyl isothiocyanate in prostate cancer cells. Anticancer Res. 2006;26(2A):1225-30.

420. Wang L, Beklemisheva A, Liu X, Ferrari A, Feng J, Chiao J. Dual action on promoter demethylation and chromatin by an isothiocyanate restored GSTP1 silenced in prostate cancer. Mol Carcinog: Published in cooperation with the University of Texas MD Anderson Cancer Center. 2007;46(1):24-31.

421. Ma X, Fang Y, Beklemisheva A, Dai W, Feng J, Ahmed T, et al. Phenylhexyl isothiocyanate inhibits histone deacetylases and remodels chromatins to induce growth arrest in human leukemia cells. Int J Oncol. 2006;28(5):1287-93.

422. Abbaoui B, Telu KH, Lucas CR, Thomas-Ahner JM, Schwartz SJ, Clinton SK, et al. The impact of cruciferous vegetable isothiocyanates on histone acetylation and histone phosphorylation in bladder cancer. J Proteome. 2017;156:94-103.

423. Ashkenazi S, Plotnikov A, Bahat A, Ben-Zeev E, Warszawski S, Dikstein R. A novel allosteric mechanism of NF-KB dimerization and DNA binding targeted by an anti-inflammatory drug. Mol Cell Biol. 2016;36:00895-15.

424. Heyninck K, Lahtela-Kakkonen M, Van der Veken P, Haegeman G, Berghe W. Withaferin A inhibits NF-kappaB activation by targeting cysteine 179 in IKKB. Biochem Pharmacol. 2014;91(4):501-9.

425. Lv TZ, Wang GS. Antiproliferation potential of withaferin a on human osteosarcoma cells via the inhibition of G2/M checkpoint proteins. Exp Ther Med. 2015;10(1):323-9. 
426. Bargagna-Mohan P, Hamza A, Kim Y-E, YKA H, Mor-Vaknin N, Wendschlag $N$, et al. The tumor inhibitor and antiangiogenic agent withaferin a targets the intermediate filament protein vimentin. Chem Biol. 2007;14(6):623-34.

427. Kim S-H, Hahm E-R, Arlotti JA, Samanta SK, Moura MB, Thorne SH, et al. Withaferin $A$ inhibits in vivo growth of breast cancer cells accelerated by Notch2 knockdown. Breast Cancer Res Treat. 2016;157(1):41-54.

428. Antony ML, Lee J, Hahm E-R, Kim S-H, Marcus Al, Kumari V, et al. Growth arrest by the antitumor steroidal lactone withaferin $A$ in human breast cancer cells is associated with down-regulation and covalent binding at cysteine 303 of $\beta$-tubulin. J Biol Chem. 2014;289(3):1852-65.

429. Stan SD, Hahm E-R, Warin R, Singh SV. Withaferin A causes FOXO3a-and Bim-dependent apoptosis and inhibits growth of human breast cancer cells in vivo. Cancer Res. 2008;68(18):7661-9.

430. vel Szic KS, de Beeck KO, Ratman D, Wouters A, Beck IM, Declerck K, et al. Pharmacological levels of Withaferin A (Withania somnifera) trigger clinically relevant anticancer effects specific to triple negative breast cancer cells. PLoS One. 2014;9(2):e87850.

431. vel Szic KS, Declerck K, Crans RA, Diddens J, Scherf DB, Gerhäuser C, et al. Epigenetic silencing of triple negative breast cancer hallmarks by Withaferin A. Oncotarget. 2017;8(25):40434

432. Ndlovu MN, Van Lint C, Van Wesemael K, Callebert P, Chalbos D, Haegeman G, et al. Hyperactivated NF-kB and AP-1 transcription factors promote highly accessible chromatin and constitutive transcription across the interleukin- 6 gene promoter in metastatic breast cancer cells. Mol Cell Biol. 2009:29(20):5488-504.

433. Rayman MP. Selenium and human health. Lancet. 2012;379(9822):1256-68.

434. Ohta Y, Suzuki KT. Methylation and demethylation of intermediates selenide and methylselenol in the metabolism of selenium. Toxicol Appl Pharmacol. 2008;226(2):169-77.

435. Mariath $A B$, Bergamaschi DP, Rondó PH, Ana CAT, de Fragas HP, Abbade JF, et al. The possible role of selenium status in adverse pregnancy outcomes. Br J Nutr. 2011;105(10):1418-28.

436. Xiang N, Zhao R, Song G, Zhong W. Selenite reactivates silenced genes by modifying DNA methylation and histones in prostate cancer cells. Carcinogenesis. 2008;29(11):2175-81.

437. Davis CD, Uthus EO, Finley JW. Dietary selenium and arsenic affect DNA methylation in vitro in Caco-2 cells and in vivo in rat liver and colon. J Nutr. 2000;130(12):2903-9.

438. de Miranda JX, de Oliveira AF, de Conti A, Dagli MLZ, Moreno FS, Ong TP. Effects of selenium compounds on proliferation and epigenetic marks of breast cancer cells. J Trace Elem Med Biol. 2014;28(4):486-91.

439. Davis CD, Uthus EO. Dietary folate and selenium affect dimethylhydrazineinduced aberrant crypt formation, global DNA methylation and one-carbon metabolism in rats. J Nutr. 2003;133(9):2907-14.

440. Uthus EO, Ross SA, Davis CD. Differential effects of dietary selenium (Se) and folate on methyl metabolism in liver and colon of rats. Biol Trace Elem Res. 2006;109(3):201-14.

441. Armstrong KM, Bermingham EN, Bassett SA, Treloar BP, Roy NC, Barnett MP. Global DNA methylation measurement by HPLC using low amounts of DNA. Biotechnol J. 2011;6(1):113-7.

442. Zeng H, Yan L, Cheng W-H, Uthus EO. Dietary selenomethionine increases exon-specific DNA methylation of the 553 gene in rat liver and colon mucosa, 2. J Nutr. 2011;141(8):1464-8.

443. Metes-Kosik N, Luptak I, DiBello PM, Handy DE, Tang SS, Zhi H, et al. Both selenium deficiency and modest selenium supplementation lead to myocardial fibrosis in mice via effects on redox-methylation balance. Mol Nutr Food Res. 2012;56(12):1812-24.

444. Yang G, Zhu Y, Dong X, Duan Z, Niu X, Wei J. TLR2-ICAM1-Gadd45a axis mediates the epigenetic effect of selenium on DNA methylation and gene expression in Keshan disease. Biol Trace Elem Res. 2014;159(1-3):69-80.

445. Tobi EW, Goeman JJ, Monajemi R, Gu H, Putter H, Zhang Y, et al. DNA methylation signatures link prenatal famine exposure to growth and metabolism. Nat Commun. 2014;5:5592.

446. Heijmans BT, Tobi EW, Stein AD, Putter $H$, Blauw GJ, Susser ES, et al. Persistent epigenetic differences associated with prenatal exposure to famine in humans. Proc Natl Acad Sci. 2008;105(44):17046-9.

447. Cropley JE, Suter CM, Beckman KB, Martin DI. Germ-line epigenetic modification of the murine Avy allele by nutritional supplementation. Proc Natl Acad Sci. 2006;103(46):17308-12.

448. Rusiecki JA, Beane Freeman LE, Bonner MR, Alexander M, Chen L, Andreotti $G$, et al. High pesticide exposure events and DNA methylation among pesticide applicators in the agricultural health study. Environ Mol Mutagen. 2017;58(1):19-29.

449. Dolinoy DC, Weidman JR, Waterland RA, Jirtle RL. Maternal genistein alters coat color and protects Avy mouse offspring from obesity by modifying the fetal epigenome. Environ Health Perspect. 2006;114(4): 567.

450. Talhout R, Schulz T, Florek E, Van Benthem J, Wester P, Opperhuizen A. Hazardous compounds in tobacco smoke. Int J Environ Res Public Health. 2011:8(2):613-28.

451. Zeilinger S, Kühnel B, Klopp N, Baurecht H, Kleinschmidt A, Gieger C, et al. Tobacco smoking leads to extensive genome-wide changes in DNA methylation. PLoS One. 2013;8(5):e63812.

452. Beach SR, Gerrard M, Gibbons FX, Brody GH, Philibert RA. A role for epigenetics in broadening the scope of pediatric care in the prevention of adolescent smoking. Epigenet Diagn Ther. 2015;1(2):91-7.

453. Beach SR, Lei MK, Ong ML, Brody GH, Dogan MV, Philibert RA. MTHFR methylation moderates the impact of smoking on DNA methylation at AHRR for African American young adults. Am J Med Genet B Neuropsychiatr Genet. 2017;174(6):608-18.

454. Richmond RC, Joubert BR. Contrasting the effects of intra-uterine smoking and one-carbon micronutrient exposures on offspring DNA methylation. Epigenomics. 2017;9(3):351-67.

455. Cornier M-A, Dabelea D, Hernandez TL, Lindstrom RC, Steig AJ, Stob NR, et al. The metabolic syndrome. Endocr Rev. 2008;29(7):777-822.

456. Waterland RA, Jirtle RL. Transposable elements: targets for early nutritional effects on epigenetic gene regulation. Mol Cell Biol. 2003;23(15):5293-300.

457. Stewart CP, Christian P, Schulze KJ, LeClerq SC, West KP Jr, Khatry SK. Antenatal micronutrient supplementation reduces metabolic syndrome in 6-to 8-year-old children in rural Nepal. J Nutr. 2009;139(8):1575-81.

458. Yajnik C, Deshpande S, Jackson A, Refsum H, Rao S, Fisher D, et al. Vitamin B12 and folate concentrations during pregnancy and insulin resistance in the offspring: the Pune Maternal Nutrition Study. Diabetologia. 2008;51(1):29-38.

459. Lucock $M$, Jones $P$, Veysey $M$, Beckett $E$. B vitamins and pollution, an interesting, emerging, yet incomplete picture of folate and the exposome. Proc Natl Acad Sci. 2017;114(20):E3878-9.

460. Zhong J, Trevisi L, Urch B, Lin X, Speck M, Coull BA, et al. B-vitamin supplementation mitigates effects of fine particles on cardiac autonomic dysfunction and inflammation: a pilot human intervention trial. Sci Rep. 2017;7:45322.

461. Wang T-C, Song Y-S, Wang H, Zhang J, Yu S-F, Gu Y-E, et al. Oxidative DNA damage and global DNA hypomethylation are related to folate deficiency in chromate manufacturing workers. J Hazard Mater. 2012;213:440-6.

462. Pilsner JR, Liu X, Ahsan H, llievski V, Slavkovich V, Levy D, et al. Genomic methylation of peripheral blood leukocyte DNA: influences of arsenic and folate in Bangladeshi adults. Am J Clin Nutr. 2007:86(4):1179-86.

463. Lambrou A, Baccarelli A, Wright RO, Weisskopf M, Bollati V, Amarasiriwardena $C$, et al. Arsenic exposure and DNA methylation among elderly men. Epidemiology (Cambridge, Mass). 2012;23(5):668.

464. Li Q, Wang HY, Chepelev I, Zhu Q, Wei G, Zhao K, et al. Stage-dependent and locus-specific role of histone demethylase Jumonji D3 (JMJD3) in the embryonic stages of lung development. PLoS Genet. 2014;10(7):e1004524.

465. Guo F, Li X, Liang D, Li T, Zhu P, Guo H, et al. Active and passive demethylation of male and female pronuclear DNA in the mammalian zygote. Cell Stem Cell. 2014;15(4):447-58.

466. Wang C, Lee J-E, Cho Y-W, Xiao Y, Jin Q, Liu C, et al. UTX regulates mesoderm differentiation of embryonic stem cells independent of H3K27 demethylase activity. Proc Natl Acad Sci. 2012;109:201204166.

467. Inoue A, Zhang Y. Replication-dependent loss of 5-hydroxymethylcytosine in mouse preimplantation embryos. Science. 2011;334(6053):194.

468. Curtis EM, Krstic N, Cook E, D'angelo S, Crozier SR, Moon RJ, et al. Gestational vitamin D supplementation leads to reduced perinatal RXRA DNA methylation: results from the MAVIDOS trial. J Bone Miner Res. 2019;34(2):231-40.

469. Xue J, Schoenrock SA, Valdar W, Tarantino LM, Ideraabdullah FY. Maternal vitamin D depletion alters DNA methylation at imprinted loci in multiple generations. Clin Epigenetics. 2016;8(1):107.

470. Anderson CM, Gillespie SL, Thiele DK, Ralph JL, Ohm JE. Effects of maternal vitamin D supplementation on the maternal and infant epigenome. Breastfeed Med. 2018;13(5):371-80.

471. Mozhui K, Smith AK, Tylavsky FA. Ancestry dependent DNA methylation and influence of maternal nutrition. PLoS One. 2015;10(3):e0118466. 
472. Li S, Iris M, Li ET. Maternal green tea extract supplementation to rats fed a high-fat diet ameliorates insulin resistance in adult male offspring. J Nutr Biochem. 2012;23(12):1655-60.

473. Long L, Li Y, Wang YD, He QY, Li M, Cai XD, et al. The preventive effect of oral EGCG in a fetal alcohol spectrum disorder mouse model. Alcohol Clin Exp Res. 2010;34(11):1929-36.

474. Castro DJ, Yu Z, Löhr CV, Pereira CB, Giovanini JN, Fischer KA, et al. Chemoprevention of dibenzo $[\mathrm{a}, \mathrm{l}]$ pyrene transplacental carcinogenesis in mice born to mothers administered green tea: primary role of caffeine. Carcinogenesis. 2008;29(8):1581-6.

475. DeVita VT Jr, DeVita-Raeburn E. The death of cancer: after fifty years on the front lines of medicine, a pioneering oncologist reveals why the war on cancer is winnable--and how we can get there: Sarah Crichton Books; 2015.

476. Ahuja N, Sharma AR, Baylin SB. Epigenetic therapeutics: a new weapon in the war against cancer. Annu Rev Med. 2016;67:73-89.

477. Azad N, Zahnow CA, Rudin CM, Baylin SB. The future of epigenetic therapy in solid tumours-lessons from the past. Nat Rev Clin Oncol. 2013;10(5):256.

478. Li Y, Buckhaults P, Cui X, Tollefsbol TO. Combinatorial epigenetic mechanisms and efficacy of early breast cancer inhibition by nutritive botanicals. Epigenomics. 2016;8(8):1019-37.

479. Vaid M, Prasad R, Singh T, Jones V, Katiyar SK. Grape seed proanthocyanidins reactivate silenced tumor suppressor genes in human skin cancer cells by targeting epigenetic regulators. Toxicol Appl Pharmacol. 2012;263(1):122-30.

480. Downing LE, Ferguson BS, Rodriguez K, Ricketts ML. A grape seed procyanidin extract inhibits HDAC activity leading to increased Ppara phosphorylation and target-gene expression. Mol Nutr Food Res. 2017;61(2):1600347.

481. Nandakumar V, Vaid M, Katiyar SK. (-)-Epigallocatechin-3-gallate reactivates silenced tumor suppressor genes, Cip1/p21 and p 16 INK4a, by reducing DNA methylation and increasing histones acetylation in human skin cancer cells. Carcinogenesis. 2011;32(4):537-44.

482. Lee Y-H, Kwak J, Choi H-K, Choi K-C, Kim S, Lee J, et al. EGCG suppresses prostate cancer cell growth modulating acetylation of androgen receptor by anti-histone acetyltransferase activity. Int J Mol Med. 2012;30(1):69-74.

483. Tiwari M, Dixit B, Parvez S, Agrawala PK. EGCG, a tea polyphenol, as a potential mitigator of hematopoietic radiation injury in mice. Biomed Pharmacother. 2017:88:203-9.

484. Zheng J, Wu C, Lin Z, Guo Y, Shi L, Dong P, et al. Curcumin up-regulates phosphatase and tensin homologue deleted on chromosome 10 through microRNA-mediated control of DNA methylation-a novel mechanism suppressing liver fibrosis. FEBS J. 2014:281(1):88-103.

485. Yu J, Peng Y, Wu L-C, Xie Z, Deng Y, Hughes T, et al. Curcumin downregulates DNA methyltransferase 1 and plays an anti-leukemic role in acute myeloid leukemia. PLoS One. 2013;8(2):e55934.

486. Ding X-Q, Wu W-Y, Jiao R-Q, Gu T-T, Xu Q, Pan Y, et al. Curcumin and allopurinol ameliorate fructose-induced hepatic inflammation in rats via miR-200a-mediated TXNIP/NLRP3 inflammasome inhibition. Pharmacol Res. 2018;137:64-75.

487. Dou H, Shen R, Tao J, Huang L, Shi H, Chen H, et al. Curcumin suppresses the colon cancer proliferation by inhibiting $W n t / \beta$-catenin pathways via miR-130a. Front Pharmacol. 2017;8:877.

488. Zhao J, Pan Y, Li X, Zhang X, Xue Y, Wang T, et al. Dihydroartemisinin and curcumin synergistically induce apoptosis in SKOV3 cells via upregulation of MiR-124 targeting midkine. Cell Physiol Biochem. 2017:43(2):589-601.

489. Tian L, Song Z, Shao W, Du WW, Zhao LR, Zeng K, et al. Curcumin represses mouse 3T3-L1 cell adipogenic differentiation via inhibiting miR-17-5p and stimulating the Wnt signalling pathway effector Tcf7l2. Cell Death Dis. 2017; 8(1):e2559.

490. Crider KS, Yang TP, Berry RJ, Bailey LB. Folate and DNA methylation: a review of molecular mechanisms and the evidence for folate's role. Adv Nutr. 2012;3(1):21-38.

491. Mentch SJ, Locasale JW. One-carbon metabolism and epigenetics: understanding the specificity. Ann N Y Acad Sci. 2016;1363(1):91-8.

492. Friso S, Choi S-W, Girelli D, Mason JB, Dolnikowski GG, Bagley PJ, et al. A common mutation in the 5,10-methylenetetrahydrofolate reductase gene affects genomic DNA methylation through an interaction with folate status. Proc Natl Acad Sci. 2002;99(8):5606-11.

493. Geoffroy A, Kerek R, Pourié G, Helle D, Guéant J-L, Daval J-L, et al. Late maternal folate supplementation rescues from methyl donor deficiencyassociated brain defects by restoring Let-7 and miR-34 pathways. Mol Neurobiol. 2017:54(7):5017-33.
494. Liu H, Tian T, Qin S, Li W, Zhang X, Wang X, et al. Folic acid deficiency enhances abeta accumulation in APP/PS1 mice brain and decreases amyloid-associated miRNAs expression. J Nutr Biochem. 2015;26(12):1502-8.

495. Kerek R, Geoffroy A, Bison A, Martin N, Akchiche N, Pourié G, et al. Early methyl donor deficiency may induce persistent brain defects by reducing Stat3 signaling targeted by miR-124. Cell Death Dis. 2013;4(8):e755.

496. Meems LM, Mahmud H, Buikema H, Tost J, Michel S, Takens J, et al. Parental vitamin $\mathrm{D}$ deficiency during pregnancy is associated with increased blood pressure in offspring via Panx1 hypermethylation. Am J Phys Heart Circ Phys. 2016;311(6):H1459-69.

497. Lopez YON, Pittas AG, Pratley RE, Seyhan AA. Circulating levels of miR-7, miR-152 and miR-192 respond to vitamin D supplementation in adults with prediabetes and correlate with improvements in glycemic control. J Nutr Biochem. 2017:49:117-22.

498. Fan P, He L, Hu N, Luo J, Zhang J, Mo L-F, et al. Effect of 1, 25-(OH) $2 \mathrm{D} 3$ on proliferation of fibroblast-like synoviocytes and expressions of proinflammatory cytokines through regulating MicroRNA-22 in a rat model of rheumatoid arthritis. Cell Physiol Biochem. 2017;42(1):145-55.

499. Gocek E, Wang X, Liu X, Liu C-G, Studzinski GP. MicroRNA-32 upregulation by 1,25-dihydroxyvitamin D3 in human myeloid leukemia cells leads to Bim targeting and inhibition of AraC-induced apoptosis. Cancer Res. 2011;71(19): 6230-9.

500. Kim J-H, Kim S-J. Overexpression of microRNA-25 by withaferin a induces cyclooxygenase-2 expression in rabbit articular chondrocytes. J Pharmaco Sci. 2014;125(1):83-90

\section{Ready to submit your research? Choose BMC and benefit from:}

- fast, convenient online submission

- thorough peer review by experienced researchers in your field

- rapid publication on acceptance

- support for research data, including large and complex data types

- gold Open Access which fosters wider collaboration and increased citations

- maximum visibility for your research: over $100 \mathrm{M}$ website views per year

At $\mathrm{BMC}$, research is always in progress.

Learn more biomedcentral.com/submissions 